\title{
MINERALIZATION OF RADIOACTIVE WASTES BY FLUIDIZED BED STEAM REFORMING (FBSR): COMPARISONS TO VITREOUS WASTE FORMS, AND PERTINENT DURABILITY TESTING
}

C.M. Jantzen

December 2008

Savannah River National Laboratory

Savannah River Nuclear Solutions

Aiken, SC 29808

Prepared for the U.S. Department of Energy Under

Contract Number DE-AC09-08SR22470

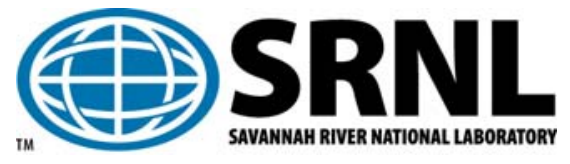


WSRC-STI-2008-00268

Revision 0

\section{DISCLAIMER}

This work was prepared under an agreement with and funded by the U.S. Government. Neither the U. S. Government or its employees, nor any of its contractors, subcontractors or their employees, makes any express or implied:

1. warranty or assumes any legal liability for the accuracy, completeness, or for the use or results of such use of any information, product, or process disclosed; or

2. representation that such use or results of such use would not infringe privately owned rights; or

3. endorsement or recommendation of any specifically identified commercial product, process, or service.

Any views and opinions of authors expressed in this work do not necessarily state or reflect those of the United States Government, or its contractors, or subcontractors.

Printed in the United States of America

Prepared for

U.S. Department of Energy 
Key Words: waste forms, mineral, durability, long-term performance.

Retention: Permanent

\section{MINERALIZATION OF RADIOACTIVE WASTES BY FLUIDIZED BED STEAM REFORMING (FBSR): COMPARISONS TO VITREOUS WASTE FORMS, AND PERTINENT DURABILITY TESTING}

C.M. Jantzen

December 2008

Savannah River National Laboratory

Savannah River Nuclear Solutions

Aiken, SC 29808

Prepared for the U.S. Department of Energy Under

Contract Number DE-AC09-08SR22470

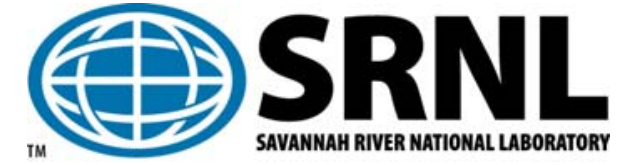




\section{REVIEWS AND APPROVALS}

AUTHORS:

Carol M. Jantzen, Environmental \& Processing Technology

Date

\section{TECHNICAL REVIEWERS:}

James C. Marra, Materials Science \& Technology

Date

Charles L. Crawford, Environmental \& Processing Technology

Date

\section{APPROVERS:}

Connie C. Herman, Manager, Environmental \& Processing Technology

Date

Jeffrey C. Griffin, Manager, Environmental \& Processing Technology

Date

\section{CUSTOMERS:}

Kevin Ryan, THOR $^{\circledR}$ Treatment Technologies

Date 


\section{EXECUTIVE SUMMARY}

The Savannah River National Laboratory (SRNL) was requested to generate a document for the Washington State Department of Ecology and the U.S. Environmental Protection Agency that would cover the following topics:

- A description of the mineral structures produced by Fluidized Bed Steam Reforming (FBSR) of Hanford type Low Activity Waste (LAW) waste, especially the cage structured minerals and how they are formed.

- How the mineral cage structured minerals contain some contaminants, while others become part of the basic mineral structure.

- Possible contaminant release mechanisms from the mineral structures.

- Appropriate analyses to evaluate these release mechanisms.

- Why the appropriate analyses are comparable to the existing Hanford glass dataset.

Mineral waste forms, which include mineral assemblages formed by FBSR, those formed by Hot Isostatic Pressing (HIPing) such as SYNthetic ROCk (SYNROC), Hot Uniaxial Pressing (HUPing), and those formed by Cold Uniaxial Pressing (CUPing) and sintering (SYNROC, supercalcine ceramics, tailored ceramics, and $\mathrm{Pu}$ ceramics) possess what are referred to as short range order (SRO), medium range order (MRO), and long range order (LRO). The SRO has a radius of influence $\sim 1.6-3 \AA$ around a central atom or first nearest neighboring atoms, the medium-range order has a radius of influence $\sim 3-6 \AA$ which encompasses secondand third-nearest neighbor environments around a central atom, and the long range order extends beyond third-neighbor environments and gives the crystalline mineral structures their crystallographic periodicity.

In the sodium aluminosilicate (NAS) FBSR mineral structures, the contaminants in the cage shaped structures and those external to the cage like structures are all bound ionically to oxygen atoms. The NAS minerals form from the sodium in the LAW waste and a processing additive (kaolin clay), which provides the $\mathrm{SiO}_{2}$ and $\mathrm{Al}_{2} \mathrm{O}_{3}$. Other mineral phases containing phosphate, boron, iron, and other alkali or alkaline earth elements could form depending on the waste composition and the process additives. The NAS cage structured feldspathoid minerals such as sodalite, nosean, and nepheline, which are common to FBSR and supercalcine ceramic waste forms, are formed by SRO and MRO structures $\left(\mathrm{SiO}_{4}\right)^{-4}$ and $\left(\mathrm{AlO}_{4}\right)^{-5}$ tetrahedra), which are joined by sharing one or more of the four oxygen atoms with another tetrahedra; the linking oxygens are known as bridging oxygen bonds. The tetrahedra are arranged to form a cage (sodalite, nosean) or rings (nepheline) via one or two of the tetrahedral oxygen atoms, while the other tetrahedral oxygen atoms (known as non-bridging oxygens) are available to bond ionically with the cations in the cage or outside the cage. These cations may be alkali, alkaline earths, hazardous, or radioactive species. The cage and/or ring structures are repeated in the structure at regular periodicity, which is the LRO characteristic of mineral/crystalline structures. The LRO provides shorter and more regular 
oxygen-cation (ionic) bonding and a periodic ordering, which makes the contaminant retention in mineral/ceramic waste forms greater than glass.

The NAS FBSR minerals are formed by destabilization of kaolin clay at the moderate processing temperature $\left(700-750^{\circ} \mathrm{C}\right)$. In kaolin clay the aluminum atom is octahedrally coordinated (six nearest neighbors instead of four). The aluminum atom is surrounded by 2 oxygen atoms and four $\mathrm{OH}^{-}$atoms. During processing at $700-750^{\circ} \mathrm{C}$, the four $\mathrm{OH}^{-}$atoms are vaporized, leaving the $\mathrm{Al}$ atoms in the clay unstable and amorphous at the nanoscale. The alkali in the waste reacts with the unstable Al atom and rearranges to a crystalline (mineral) lowest free energy tetrahedral configuration forming mineral species such as $\mathrm{NaAlSiO}_{4}$.

Glasses do not possess LRO, but they do possess SRO and MRO. Some times glasses have more highly ordered regions, referred to as clusters or quasicrystals that have atomic arrangements that approach those of crystals, but no LRO. Experimentation has confirmed that glasses contain framework units, sheet-like units, chain-like units, and monomers made up of tetrahedra of $\left(\mathrm{SiO}_{4}\right)^{-4}$, boria as $\left(\mathrm{BO}_{4}\right)^{-5 \dagger},\left(\mathrm{PO}_{4}\right)^{-3},\left(\mathrm{AlO}_{4}\right)^{-5}$, or $\left(\mathrm{BO}_{3}\right)^{-3}$ trigonal units. ${ }^{\ddagger}$ The competition for a dominant structural role causes one or more of the three types of $\left(\mathrm{SiO}_{4}\right)^{-4},\left(\mathrm{BO}_{4}\right)^{-5},\left(\mathrm{PO}_{4}\right)^{-3}$ tetrahedral units to phase separate, while $\left(\mathrm{AlO}_{4}\right)^{-5}$ tetrahedra inhibit phase separation. In borosilicate glasses, $\left(\mathrm{PO}_{4}\right)^{-3}$ will separate first, along with accompanying charge balancing cations.

If glasses contain $\left(\mathrm{SiO}_{4}\right)^{-4},\left(\mathrm{BO}_{4}\right)^{-5},\left(\mathrm{BO}_{3}\right)^{-3}$ and some $\left(\mathrm{AlO}_{4}\right)^{-5}$ they are borosilicate glasses; if they contain $\left(\mathrm{SiO}_{4}\right)^{-4}$ and $\left(\mathrm{AlO}_{4}\right)^{-5}$ they are aluminosilicate glasses; if they contain only $\left(\mathrm{BO}_{4}\right)^{-}$ ${ }^{5},\left(\mathrm{BO}_{3}\right)^{-3}$ and some $\left(\mathrm{AlO}_{4}\right)^{-5}$ they are aluminoborate glasses; and if they contain $\left(\mathrm{PO}_{4}\right)^{-3}$ and $\left(\mathrm{AlO}_{4}\right)^{-5}$ they are aluminophosphate glasses and so on. Glasses are metastable compared to crystalline minerals because crystalline species are at their lowest thermodynamic free energy. Glasses do not have LRO and thus NAS FBSR mineral structure waste forms are inherently more stable and tend to be as durable or more durable than vitreous waste forms, depending on which elements are being monitored, i.e. SRO structural species such as Si and $\mathrm{Al}$ or cations that leach by ion exchange that are bonded to the oxygen cations of the SRO structures.

Because of the similarity of the SRO and MRO in mineral (ceramic) and vitreous waste forms the dissolution mechanisms (contaminant release mechanisms) are similar. Mineral waste forms can afford better retention of cationic species compared to glass waste forms due to the LRO of the mineral structure and the regularity of the coordination and bonding of a given coordination polyhedra in which a cation or radionuclide resides. While the activation energy required to break an Si-O, Al-O, B-O bond may be similar in a glass and a ceramic/mineral due to the $\mathrm{SRO}$, the $\left(\mathrm{SiO}_{4}\right)^{-4},\left(\mathrm{BO}_{4}\right)^{-5},\left(\mathrm{BO}_{3}\right)^{-3}$ and $\left(\mathrm{AlO}_{4}\right)^{-5}$ are more rigidly retained in a mineral structure due to the LRO and periodicity (repeated pattern) of the polyhedra.

In mineral waste forms, as in glass, the molecular structure controls contaminant release by

\footnotetext{
${ }^{\dagger}$ where B is surrounded by four oxygen atoms or IV coordinated

$\$$ where B is surrounded by three oxygen atoms or III coordinated
} 
establishing the distribution of ion exchange sites, hydrolysis sites, and the access of water to those sites. It has been demonstrated experimentally that ion exchange in glass occurs along percolation channels that exist in glass. The percolation channels in glass are defined by the SRO and MRO structure of a given glass since glass has no LRO. The cations in the percolation channels are ionically bonded to the non-bridging oxygen (NBO) bonds, just as they are in the more ordered crystalline mineral species. In the mineral waste forms there are no percolation channels and dissolution with water must attack the ionically bonded lattice from the surface. The basic difference is that there may be fewer bonds around a given cation in a glass or the bonds may have varying lengths compared to those in a crystalline or mineral waste form. Examples include: 1) The release of $\mathrm{Na}$ from crystalline nepheline is slower than that from a glass with the identical composition; 2) Ceramic Pu waste forms are more durable than vitreous $\mathrm{Pu}$ waste forms, and 3) Ceramics such as SYNROC and high Al Tailored Ceramics are more durable than borosilicate glass.

The appropriate analyses for the determination of the release of contaminants from ceramics are the same as those for glass and the glass ceramic known as "glass bonded sodalite." Because the FBSR product is granular, certain monolithic tests like ASTM C1220 (MCC-1 described in the appendix) cannot be performed unless the granular product is monolithed. However, the standard suite of durability tests applicable to both granular or ground up monolithic waste forms, i.e. the Product Consistency Test (PCT or ASTM C1285), the Single Pass Flowthrough Test (SPFT or ASTM C1662), and the Pressure Unsaturated Flowthrough (PUF) test, provide the different parameters necessary for an understanding of the durability of one waste form compared to the other and/or the mechanisms by which a waste form degrades.

In most studies, the PCT is used to determine the maximum rate of radionuclide release if the leaching is congruent (i.e., the release rate of contaminants is essentially the same as the release of $\mathrm{Na}$ ) and the SPFT test is used to monitor the rate of matrix degradation. It should also be noted that the SPFT test originated for the geologic study of the degradation of single phase minerals in nature, but there are consistency issues between laboratory studies regarding the manner in which surface areas of the waste forms are measured and in the choice of buffer solutions for performing the tests. The consensus has been to use geometric surface area for smooth surface waste forms (glasses and glass ceramics) and BrunauerEmmett-Teller (BET) surface area for ceramic and mineral waste forms to account for surface roughness. If the leach rates of the FBSR mineral product are expressed conservatively, i.e. without the SA term, then glass and FBSR product have similar durability. If the leach rates of the FBSR product are expressed with the surface roughness term which is much greater than the surface roughness of glass, then the FBSR product is two orders of magnitude more durable than glass.

The durability testing (PCT, ASTM C1285) on the FBSR mineral waste form has shown that an Al-buffering mechanism controls the release of alkali ( $\mathrm{Na}, \mathrm{K}$, and $\mathrm{Cs}$ ) elements and the solution $\mathrm{pH}$ controls the release of the other constituents like Re (simulant for $\mathrm{Tc}^{99}$ ), $\mathrm{S}$, and $\mathrm{Si}$. This is due to the high alumina content of the FBSR mineral products, which provides a natural aluminosilicate buffering mechanism that inhibits leaching. This mechanism is known to occur in nature during weathering of aluminosilicate mineral analogs. Since 
glasses do not normally contain high alumina contents (high alumina glasses are too viscous to process), such an aluminosilicate buffering mechanism has not been observed for glass waste forms. In glass $\mathrm{Na}, \mathrm{B}$, and $\mathrm{Li}$ releases are congruent with the maximum radionuclide release rate, which happens to be the element $\mathrm{Tc}^{99}$. Because ceramics normally leach incongruently, the leach rates of Re (surrogate for $\mathrm{Tc}^{99}$ ) from the NAS FBSR mineral phases should be compared to the leach rates of $\mathrm{Na}$ or B from LAW glass, i.e. the release of B from the LAW glass standard known as Low Activity Reference Material (LRM) during PCT testing is $0.55 \mathrm{~g} / \mathrm{m}^{2}$, the Hanford PCT specification is $2 \mathrm{~g} / \mathrm{m}^{2}$, and the release of B from the AN-102 radioactive waste glass tested at SRNL is $0.29 \mathrm{~g} / \mathrm{m}^{2}$. The Re release from the 2002 FBSR LAW (AN-107) product is $0.22-0.29 \mathrm{~g} / \mathrm{m}^{2}$, while the Cs release is $0.16 \mathrm{~g} / \mathrm{m}^{2}$. No correlation exists between the congruent $\mathrm{Na}$ release rates of LAW glass and the incongruent Na release from the FBSR LAW mineral waste form. The leachate buffering mechanism and the fact that the FBSR mineral product contains the radionuclides in a structure that has LRO makes the FBSR mineral products more durable than glass.

Durability testing (SPFT and PUF) performed by the Pacific Northwest National Laboratory (PNNL) also indicates that the FBSR mineral product is more durable than LAW glass by $\sim 2$ orders of magnitude. Additional SPFT testing at SRNL demonstrated that all of the mineral species present in the FBSR product (nepheline, nosean, and sodalite) share the same bonding (SRO, MRO and LRO) in terms of the aluminosilicate matrix, i.e. a basic structural framework formula $\left[\mathrm{AlSiO}_{4}{ }^{-}\right]_{6}$ that forms the rings and cages in which the radionuclides, halides, and sulfates are bonded. The SRNL durability data indicated that the structural framework leaches congruently and that the $\operatorname{Re}\left(\mathrm{Tc}^{99}\right)$ and $\mathrm{S}$ cannot be released from the cage until part of the tetrahedral components of the cage themselves degrade. The reaction order for nepheline dissolution determined for the FBSR LAW mineral components (nepheline and sodalite) in the SRNL study agree with those measured on single crystal natural nepheline and with the data on glass bonded sodalite ceramic waste forms at comparable dissolution temperatures $\left(80-90^{\circ} \mathrm{C}\right)$. The PNNL data is not in agreement with the data on natural nepheline and/or the data on glass bonded sodalites. However, the durability (as indicated by the reaction order) measured for the LAW FBSR mineral product by both SRNL and PNNL are lower than the reaction order measured on nepheline glass and on a simple five component High Level Waste glass at similar dissolution temperatures. This data again demonstrates that the FBSR product is more durable than glass since SPFT testing includes the exposed surface area of the waste form. 


\section{TABLE OF CONTENTS}

EXECUTIVE SUMMARY ii

LIST OF FIGURES Vii

LIST OF TABLES I ix

LIST OF ACRONYMS $\quad x$

1.0 INTRODUCTION 2

1.1 Definition of Waste Forms 3

1.2 Historical Perspective of Glass Versus High and Moderate Temperature Mineral Waste Forms

2.0 THE ROLE OF ATOMIC BONDING IN GLASS AND MINERAL WASTE FORMS

ON DURABILITY

3.1 The FBSR Mineral Phases $\quad 13$

3.2 How the FBSR Mineral Structures Form: Nanoscale Reactions 14

3.3 Bonding of Radionuclides and Contaminants 19

3.4 Role of REDuction/OXidation (REDOX) on Bonding of Radionuclides and

$\begin{array}{ll}\text { Contaminants } & 24\end{array}$

3.5 Possible Contaminant Release Mechanisms from FBSR Mineral Structures $\quad 27$

3.5.1 Similarity of Glass and Mineral Dissolution Mechanisms 27

3.6 Current Knowledge About FBSR Mineral Dissolution and Contaminant Release $\quad 33$

3.7 How FBSR Durability Testing Compares to the Hanford Glass Testing 43

4.0 ACKNOWLEDGEMENTS 45

APPENDIX A-VITRIFIED WASTE FORM DURABILITY AND REDOX 46

A.1 Glass Durability and the Homogeneity Assumption 46

A.2 REDOX Effects on Glass Durability 49

B.1 Commercialization $\quad 52$

B.2 Pilot Scale and Engineering Scale Demonstrations $\quad 52$

B.3 Clean Air Act Compliance $\quad 53$

APPENDIX C_-The Durability Test Protocols Currently In Use 56

C.1 ASTM C1220 (Monolith Immersion Test) 56

C.2 ASTM C1285 (Product Consistency Test) 57

C.3 ASTM C1308 (Accelerated Leach Test) 57

C.4 ASTM C1662 (Single-Pass Flow-Through Test) 58

C.5 ANL Drip Test

C.6 PNNL Pressurized Unsaturated Flow Test

C.7 Vapor Hydration Test (VHT) 60

APPENDIX D-DURABILITY TESTING: SURFACE AREA MEASURMENT AND CHOICE OF BUFFERED LEACHANTS $\quad 62$

D.1 Reporting Units and Test Acceleration $\quad 62$

D.2 Durability Test Protocols: Impact of Leachants 66

D.2.1 Product Consistency Test (ASTM C1285) 66

D.2.2 Single Pass Flow Through (ASTM 1662) 66

APPENDIX E-ALL REFERENCES 


\section{LIST OF FIGURES}

Figure 1. An example of short range order (SRO) structural units (tetrahedra and octahedra) in glass and mineral structures.

Figure 2. (a) Long range order of $\left(\mathrm{SiO}_{4}\right)^{-4}$ tetrahedra in crystalline $\mathrm{SiO}_{2}$. (b) Polymerized structure with lack of long range order of $\left(\mathrm{SiO}_{4}\right)^{-4}$ tetrahedra in amorphous $\mathrm{SiO}_{2}, \ldots \ldots . .9$

Figure 3. Atomic arrangement in a sodium silicate glass. .10

Figure 4. A modified random network (MRN) for a glass of nominal composition $\mathrm{M}_{2} \mathrm{O}_{3}\left(\mathrm{G}_{2} \mathrm{O}_{3}\right)_{2}$, where $\mathrm{M}$ represents the modifying cations and $\mathrm{G}$ represents the tetrahedral cations.

Figure 5. Comparison of dissolution rates of crystalline albite vs. albite glass from SPFT testing.

Figure 6. Atomic structures of various clays (kaolin, bentonite-montmorillonite, illite)...........16

Figure 7. (a) Structure of Zeolite-A [37] showing alternate $\mathrm{Al}$ and $\mathrm{Si}$ atom ordering but omitting the tetrahedral oxygens around each $\mathrm{Al}$ and $\mathrm{Si}$; (b) Structure of Sodalite showing the tetrahedral oxygens (bridging and non-bridging) around each $\mathrm{Al}$ and $\mathrm{Si}$ but omitting the $\mathrm{Al}$ and $\mathrm{Si}$ atom ordering.

Figure 8. Structure of Sodalite showing (a) two-dimensional projection of the (b) threedimensional structure and (c) the four fold ionic coordination of the $\mathrm{Na}$ site to the $\mathrm{Cl}^{-}$ion and three framework oxygen bonds.

Figure 9. Two-dimensional representation of the structure of nepheline showing the smaller 8 oxygen sites that are occupied by $\mathrm{Na}$ and the larger 9 oxygen sites that are occupied by $\mathrm{K}$ and larger ions such as $\mathrm{Cs}$ and $\mathrm{Ca}$.

Figure 10. The crystal structure of $\mathrm{CsAlSiO}_{4}$ (above) and $\mathrm{RbAlSiO}_{4}$ (below) viewed down the crystallographic c-axis.

Figure 11. Crystal structure of monoclinic sodium deficient nepheline $\left(\mathrm{Na}_{7.85} \mathrm{Al}_{7.85} \mathrm{Si}_{8.15} \mathrm{O}_{32}\right.$ showing the sixfold rings made of $\left(\mathrm{SiO}_{4}\right)^{-4}$ and $\left(\mathrm{AlO}_{4}\right)^{-5}$ tetrahedra. 24

Figure 12. Comparison of the bonding of $\mathrm{SO}_{4}$ and $\mathrm{MoO}_{4}$ in glass and in the sodalite family

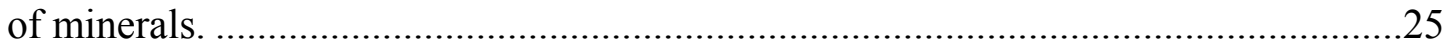

Figure 13. Bonding of Re in the perrhenate sodalite ..............................................................26

Figure 14. Electromotive Force (EMF) series developed by Schreiber for FBSR reactions.........27

Figure 15. Schematic illustration of the basalt glass dissolution mechanism................................31

Figure 16. Relationship between surface area $\left(\mathrm{SA}_{\mathrm{BET}}\right)$ and $\mathrm{PCT}$ final leachate $\mathrm{pH} . . . \ldots \ldots \ldots \ldots \ldots . . . . . . .36$

Figure 17. Linearity of alkali and alumina released to solution.................................................36

Figure 18. Leachate Re, S, and Si concentrations as a function of the $\mathrm{pH}$ of the final

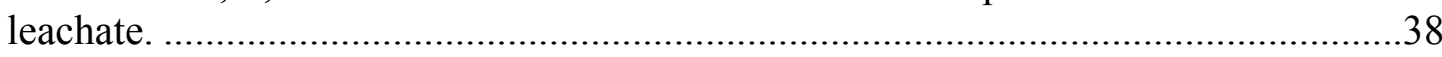

Figure 19. Interpretation of dissolution in the Hanford LAW FBSR mineral waste forms...........41

Figure 20. Scanning Electron Microscopy (SEM) and Energy Dispersive Analysis by X-Ray (EDAX) of a clay core of an FBSR granule.

Figure 21. Comparison of the Re release from LAW Envelope C, LAW Envelope A, and INL SBW mineral waste forms to measured waste form REDOX. .44

Figure 22. Examples of glass phase separations. 
Figure 23. Leaching of a simulated SRNL HLW devitrified waste glass showing a triangular spinel crystal with acmite needles growing out of it devitrified HLW borosilicate glass.

Figure 24. Relation of the imposed oxygen fugacity $\left(-\log f_{\mathrm{O}_{2}}\right)$ to the analyzed REDOX ratio expressed as $\log \mathrm{Fe}^{2+} / \Sigma \mathrm{Fe}$ of multivalent elements doped into SRL-131 melt at $1150^{\circ} \mathrm{C}$.

Figure 25. Simplified Dual Fluidized Bed Steam Reformer Flowsheet. .................................55

Figure 26. Rough surface of an FBSR waste form (left) and smooth surface of vitrous waste form (right). 


\section{LIST OF TABLES}

Table I. $\quad$ Phases Identified by X-Ray Diffraction in FBSR Samples of Processed AN-107... 13

Table II. Similarity of Mineral Phases in FBSR Waste Forms to Other HLW/LAW Waste

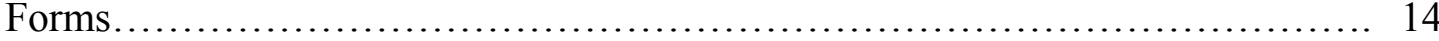

Table III. Structurally Related Zeolite-A and Cubic Sodalite Phases....................... 18

Table IV. PCT Performance of FBSR Sample SCT02-098-FM and the Durability Response of Known Glass Standards Using Geometric Surface Area.................... 34

Table V. Reaction order in $\mathrm{pH}$ for nosean, crystalline nepheline, and nepheline glass........ 41

Table VI. Composition of $\mathrm{pH}$ Buffers Used in Various SPFT Tests...................... 68 


\section{LIST OF ACRONYMS}

\begin{tabular}{|c|c|}
\hline ALT & Accelerated Leach Test \\
\hline ANL & Argonne National Laboratory \\
\hline ANL-W & Argonne National Laboratory - West \\
\hline ASTM & American Society for Testing and Materials \\
\hline BET & Brunauer-Emmett-Teller \\
\hline $\mathrm{BO}$ & Bridging Oxygen \\
\hline CAA & Clean Air Act \\
\hline CCIM & Cold Crucible Induction Melter \\
\hline CRR & Carbon Reduction Reformer \\
\hline CWF & Ceramic Waste Form \\
\hline DMR & Denitration and Mineralizing Reformer \\
\hline DOE & Department of Energy \\
\hline DWPF & Defense Waste Processing Facility \\
\hline EA & Environmental Assessment \\
\hline EBS & Engineered Barrier System \\
\hline EDAX & Energy Dispersive Analysis by X-ray \\
\hline EM & Electron Microprobe \\
\hline EMF & Electro Motive Force \\
\hline EPA & Environmental Protection Agency \\
\hline EXAFS & Extended X-Ray Absorption Fine Structure \\
\hline FBSR & Fluidized Bed Steam Reforming \\
\hline FG & Fluidizing Gas \\
\hline GCM & Glass Composite Material \\
\hline GNEP & Global Nuclear Energy Partnership \\
\hline HRI & Hazen Research Inc. \\
\hline HIPing & Hot Isostatic Pressing \\
\hline HLW & High Level Waste \\
\hline HTF & High Temperature Filter \\
\hline HWC & Hazardous Waste Combustor \\
\hline IR & Infrared \\
\hline ILAW & Immobilized Low Activity Waste \\
\hline INL & Idaho National Laboratory \\
\hline LAW & Low Activity Waste \\
\hline LAWR & Low Activity Waste Recycle \\
\hline LLNL & Lawrence Livermore National Laboratory \\
\hline LLRW & Low Level Radioactive Waste \\
\hline LRO & Long Range Order \\
\hline MACT & Maximum Achievable Control Technology \\
\hline $\mathrm{MCC}$ & Materials Characterization Center \\
\hline MRO & Medium Range Order \\
\hline NAS & Na-Al-Si (Sodium Aluminosilicate) \\
\hline $\mathrm{NBO}$ & Non-Bridging Oxygen \\
\hline PA & Performance Assessment \\
\hline PCT & Product Consistency Test \\
\hline PNNL & Pacific Northwest National Laboratory \\
\hline PR & Product Receiver \\
\hline PUF & Pressure Unsaturated Flowthrough \\
\hline RCRA & Resource Conservation \& Recovery Act \\
\hline REDOX & REDuction/OXidation \\
\hline SA & Surface Area \\
\hline
\end{tabular}


WSRC-STI-2008-00268

Revision 0

\begin{tabular}{|l|l|}
\hline SAIC & Science Applications International Corporation \\
\hline SBW & Sodium Bearing Waste \\
\hline SEM & Scanning Electron Microscopy \\
\hline SIMS & Secondary Ion Mass Spectroscopy \\
\hline SPF & Studsvik Processing Facility \\
\hline SPFT & Single Pass Flow Through \\
\hline SRS & Savannah River Site \\
\hline STAR & Science \& Technology Application Research \\
\hline SRNL & Savannah River National Laboratory \\
\hline SRO & Short Range Order \\
\hline TEM & Transmission Electron Microscopy \\
\hline THOR & THermal Organic Reduction \\
\hline TSPA-LA & Total System Performance Assessment-License Application \\
\hline TST & Transition State Theory \\
\hline TTT & THOR \\
\hline VHT Treatment Technologies, LLC & Vapor Hydration Test \\
\hline UTS & Universal Treatment Standards \\
\hline WAC & Waste Acceptance Criteria \\
\hline WIPP & Waste Isolation Pilot Plant \\
\hline WGSR & Water Gas Shift Reaction \\
\hline WSRC & Washington Savannah River Company \\
\hline XRD & X-Ray Diffraction \\
\hline
\end{tabular}




\subsection{INTRODUCTION}

The Savannah River National Laboratory (SRNL) was requested to generate a document for the Washington State Department of Ecology and the U.S. Environmental Protection Agency that would cover the following topics:

- A description of the mineral structures produced by Fluidized Bed Steam Reforming (FBSR) of Hanford type Low Activity Waste (LAW including LAWR which is LAW melter recycle waste) waste, especially the cage structured minerals and how they are formed.

- How the cage structured minerals contain some contaminants, while others become part of the mineral structure (Note that all contaminants become part of the mineral structure and this will be described in the subsequent sections of this report).

- Possible contaminant release mechanisms from the mineral structures.

- Appropriate analyses to evaluate these release mechanisms.

- Why the appropriate analyses are comparable to the existing Hanford glass dataset.

In order to discuss the mineral structures and how they bond contaminants a brief description of the structures of both mineral (ceramic) and vitreous waste forms will be given to show their similarities. By demonstrating the similarities of mineral and vitreous waste forms on atomic level, the contaminant release mechanisms of the crystalline (mineral) and amorphous (glass) waste forms can be compared. This will then logically lead to the discussion of why many of the analyses used to evaluate vitreous waste forms and glass-ceramics (also known as glass composite materials) are appropriate for determining the release mechanisms of LAW/LAWR mineral waste forms and how the durability data on LAW/LAWR mineral waste forms relate to the durability data for LAW/LAWR glasses.

The text will discuss the LAW mineral waste form made by FBSR. The nanoscale mechanism by which the minerals form will be also be described in the text. The appropriate analyses to evaluate contaminant release mechanisms will be discussed, as will the FBSR test results to date and how they compare to testing performed on LAW glasses. Other details about vitreous waste form durability and impacts of REDuction/OXidation (REDOX) on durability are given in Appendix A. Details about the FBSR process, various pilot scale demonstrations, and applications are given in Appendix B. Details describing all the different leach tests that need to be used jointly to determine the leaching mechanisms of a waste form are given in Appendix C. Cautions regarding the way in which the waste form surface area is measured and in the choice of leachant buffers (if used) are given in Appendix D. 


\subsection{Definition of Waste Forms}

Vitreous waste forms can include silicate based glasses, borosilicate glasses, iron phosphate glasses, etc. Vitreous waste forms are amorphous and leach congruently. ${ }^{f}$ Vitreous waste forms can crystallize during cooling and thus can become glass ceramics as discussed in Appendix A. Vitreous waste forms can be made by a variety of melting technologies that include Joule heated melters and Cold Crucible Induction Melters (CCIM).

Crystalline (ceramic or mineral) waste forms include Na-Al-Si sodium aluminosilicate (NAS) mineral/ceramics, silicate based ceramics (supercalcines ${ }^{\ddagger}$ ), aluminate based ceramics (Tailored ceramics), and titania based ceramics (SYNthetic ROCk known as SYNROC). Crystalline waste forms leach incongruently. ${ }^{\dagger}$ These waste forms can be formed by FBSR (NAS forms), Hot Isostatic Pressing (HIPing) (titania and aluminate forms), Hot Uniaxial Pressing (HUPing) (titania forms), and those formed by Cold Uniaxial Pressing (CUPing) and sintering (titania forms including Pu ceramics, aluminate forms, silicate forms). Of these the FBSR process has the advantage that it is the lowest temperature process and the only continuous process for forming mineral waste forms. The other technologies are higher temperature and batch processes.

\subsection{Historical Perspective of Glass Versus High and Moderate Temperature Mineral Waste Forms}

Many waste forms (glasses, ceramics/minerals, and hybrid glass-ceramics) are made by thermal treatment at temperatures between $1000-1500^{\circ} \mathrm{C}$ (melting, HIPing, or sintering), while mineral waste forms made by FBSR are made at more moderate temperatures (700$750^{\circ} \mathrm{C}$ ). In both cases a glass or a mineralizing material is added to waste and thermally processed. During vitrification glass formers (premade frit and/or crystalline minerals) or additives that include oxides such as $\mathrm{SiO}_{2}, \mathrm{Al}_{2} \mathrm{O}_{3}, \mathrm{Fe}_{2} \mathrm{O}_{3}$ and fluxes like $\mathrm{B}_{2} \mathrm{O}_{3}, \mathrm{Na}_{2} \mathrm{O}, \mathrm{Li}_{2} \mathrm{O}$, etc are added to waste and co-processed. In the early 1960's mixtures of clay and frit were used in the U.S. and France as glass forming additives.[1,2] The frit is amorphous as it is made by ultrarapid quenching of a melt. Frit remelts and then rapidly reacts with waste at elevated temperatures $\left(\geq 1000^{\circ} \mathrm{C}\right)$. Crystalline or mineral glass formers must first be melted

Congruent dissolution of a waste form is the dissolving of species in their stoichiomentric amounts. For congruent dissolution, the rate of release of a radionculide from the waste form is proportional to both the dissolution rate of the waste form and the relative abundance of the radionculide in the waste form. Thus for borosilicate glass ${ }^{99} \mathrm{Tc}$ is released at the same rate, congruently, as $\mathrm{Na}, \mathrm{Li}$, and $\mathrm{B}$.

\$ Supercalcines were the high temperature silicate based "natural mineral" assemblages proposed for HLW waste stabilization in the United States (1973-1985).

$\dagger \quad$ Incongruent dissolution of a waste form means that some of the dissolving species are released preferentially to others. Incongruent dissolution is often diffusion-controlled and can be either surface reaction-limited under conditions of near saturation or mass transport-controlled. Preferential phase dissolution, ion-exchange reactions, grain-boundary dissolution, and dissolution-reaction product formation (surface crystallization and recrystallization) are among the more likely mechanism of incongruent dissolution, which will prevail, in a complex polyphase ceramic waste form. 
at the elevated temperature of the thermal treatment unit in use. Once melted, the crystalline glass formers react with waste in much the same way as frit.

Crystalline (ceramic/mineral) waste forms made by high temperature thermal treatment $\left(1300-1550^{\circ} \mathrm{C}\right)$ have been intensely investigated [3] for stabilization of HLW wastes, but were eventually abandoned in favor of borosilicate glass due to the following considerations:

- High processing temperatures $\left(>1150^{\circ} \mathrm{C}\right)$ caused vaporization of radionuclides such as $\mathrm{Tc}^{99}$ and $\mathrm{Cs}^{137}$

- The presence of a glassy intergranular phase which often adversely impacted durability, since radionuclides partitioned preferentially to the glassy phase and it was more soluble than the crystalline "radio-phases" $[4,5]$

- The tendency to undergo radiation damage at the radiation doses experienced with HLW in the form of metamictization (transformation of the crystalline mineral structures to an amorphous structure)

- Complex processing (isostatic pressing followed by sintering and/or hot isostatic pressing, HIPing)

- Batch processing (poor attainment/throughput due to batch nature of producing small pucks or samples)

Crystalline (ceramic/mineral) waste forms made by moderate temperature $\left(700-750^{\circ} \mathrm{C}\right)$ thermal treatment using various clays as the waste form additive have not been as intensely investigated [3] as the high temperature thermal treatment waste forms. However, crystalline waste forms made from clay have been studied almost continuously since 1953.[3,6] In much of the clay research $[6,8,7]$ clays were used to sorb radionuclides and then sintered or pressed into waste forms in the absence of hydrothermal conditions. $[8,9,10,11]$ This process created sodalite-cancrinite mineral assemblages. By 1981, Roy [12] proposed low temperature hydrothermally processed low solubility phase assemblages consisting of the micas, apatite, pollucite, sodalite-cancrinite, and nepheline, many of which could be made from various clay (kaolin or bentonite) starting materials. The rationale given for not pursuing the clay based crystalline (ceramic/mineral) waste forms in the late 1970's and early 1980's was lack of an available commercial technology that could process the waste/clay mixture at moderate temperature and under hydrothermal conditions.[3] A commercial facility to continuously process radioactive wastes at moderate temperatures in a hydrothermal steam environment, with our without clay additives, became available in 1999, i.e. the Erwin, Tennessee FBSR facility (see Appendix B).[13,14]

It should be noted that the concerns expressed above regarding high temperature (1300$1550^{\circ} \mathrm{C}$ ) ceramic/mineral waste forms do not apply to the FBSR mineralization process, since the process runs at moderate temperatures $\left(700-750^{\circ} \mathrm{C}\right)$. Moreover, FBSR is a continuous process (not batch). Since low activity waste is being mineralized, the radionuclide dose is not high enough to cause metamictization (radiation damage of the crystalline structures) of the mineralized product. 


\subsection{THE ROLE OF ATOMIC BONDING IN GLASS AND MINERAL WASTE FORMS ON DURABILITY}

In mineral waste forms, as in glass, the molecular structure controls dissolution (contaminant release) by establishing the distribution of ion exchange sites, hydrolysis sites, and the access of water to those sites.[15] Mineral waste forms, which include mineral assemblages formed by FBSR, those formed by Hot Isostatic Pressing (HIPing) such as SYNthetic ROCk (SYNROC), Hot Uniaxial Pressing (HUPing), and those formed by Cold Uniaxial Pressing (CUPing) and sintering (SYNROC, supercalcine ceramics, tailored ceramics, and $\mathrm{Pu}$ ceramics) possess what are referred to as short range order (SRO), medium range order (MRO), and long range order (LRO). The SRO has a radius of influence $\sim 1.6-3 \AA$ around a central atom or first nearest neighboring atoms, i.e. polyhedra such as tetrahedral and octahedral structural units (see Figure 1).[16] Medium-range order has a radius of influence 3-6 A which encompasses second- and third-nearest neighbor environments around a central atom, and the long range order extends beyond third-neighbor environments $(>6 \AA)$ and gives the crystalline mineral structures their crystallographic periodicity.

Glasses do not possess LRO, but they do possess SRO and MRO (see Figure 1).[16] Sometimes glasses have more highly ordered regions, referred to as clusters or quasicrystals that have atomic arrangements that approach those of crystals, but no LRO. [16,17] Experimentation has confirmed that glasses contain framework units, sheet-like units, chainlike units, and monomers [18] made up of tetrahedra of $\left(\mathrm{SiO}_{4}\right)^{-4}$, boria as $\left(\mathrm{BO}_{4}\right)^{-5},\left(\mathrm{PO}_{4}\right)^{-3}$, $\left(\mathrm{AlO}_{4}\right)^{-5}$, or $\left(\mathrm{BO}_{3}\right)^{-3}$ trigonal units ${ }^{\ddagger}$ the same as crystalline mineral structures, but these units do not have the long range periodicity characteristic of mineral (crystalline) analogs. In glasses the competition for dominant tetrahedral role causes one or more of the $\left(\mathrm{SiO}_{4}\right)^{-4}$, $\left(\mathrm{BO}_{4}\right)^{-5},\left(\mathrm{PO}_{4}\right)^{-3}$ tetrahedral units to phase separate (see Appendix A) and contaminants can partition to the more soluble of the two or more glassy phases created. However, the presence of $\left(\mathrm{AlO}_{4}\right)^{-5}$ tetrahedra in glass contract the glass structure and inhibit phase separation.

In glass the central cation in the SRO tetrahedra are bonded covalently to the four surrounding oxygen atoms. The central cation in the SRO octahedra is bonded ionically to six surrounding oxygen atoms. The ctahedral are linked to each other or to an octahedral SRO via a bridging oxygen bond (BO) as shown in Figure 1. The non-bridging (NBO) atoms carry a negative charge and, in turn, bond positively charged cations like $\mathrm{Na}^{+}$and positively charged contaminants (hazardous and radioactive species) ionically. The linkage of the SRO structural units (Figure 1, Figure 2, Figure 3) create the MRO structural groups such as $(\mathrm{Cs}, \mathrm{K}, \mathrm{Na}, \mathrm{Li}) \mathrm{AlO}_{2},(\mathrm{Cs}, \mathrm{K}, \mathrm{Na}, \mathrm{Li}) \mathrm{FeO}_{2},(\mathrm{Cs}, \mathrm{K}, \mathrm{Na}, \mathrm{Li}) \mathrm{BO}_{2}$, and $(\mathrm{Cs}, \mathrm{K}, \mathrm{Na}, \mathrm{Li}) \mathrm{SiO}_{4}[19]$ or $(\mathrm{Cs}, \mathrm{K}, \mathrm{Na}) \mathrm{AlSiO}_{4}$.[20] The same type of SRO and MRO bonding that occurs in glass occurs in mineral waste forms. The primary difference with crystalline waste forms (ceramics/minerals) is that the SRO and MRO are ordered and so the mineral structures possess crystallographic long range order (LRO), while the SRO and MRO in glasses have random distributions exhibiting polymerization into rings and chains (Figure 2). Therefore a

\footnotetext{
${ }^{\dagger}$ where B is surrounded by four oxygen atoms or IV coordinated

$\$$ where B is surrounded by three oxygen atoms or III coordinated
} 
contaminant ionically bonded in glass may be bonded by fewer bonds around a given cation or the bonds may have varying lengths compared to the symmetric, regular, and periodic bonding in a crystalline or mineral lattice.

Greaves [21] recently used a technique known as Extended X-ray Absorption Fine Structure (EXAFS) to demonstrate that ion exchange occurs along percolation channels that exist in glass. He demonstrated that the channels are defined by the NBO atoms, which ionically bond to the alkali, alkaline earth or contaminant species in a glass (Figure 4). As the cation species are preferentially leached out of the channels, the leachant can then preferentially attack the Si-O NBO bond. This is in agreement with the calculations of El-Shamey [22], which indicate that a silica content of $\sim 67 \mathrm{~mol} \%$ silica in alkali alkaline-earth silicate glasses corresponds to a composition at which every silicon atom in the glass becomes associated with a basic ion as a second neighbor. Thus, in glasses with $<67 \mathrm{~mol} \%$ silica, there is always an interconnected path of nonbridging $+\mathrm{Si}-\mathrm{O}^{-}$sites that allows exchange of species between leachate solution and the glass. At $>67 \mathrm{~mol} \%$ silica, these sites are isolated from each other by the silica network $+\mathrm{Si}-\mathrm{O}-\mathrm{Si}+$ groups in the glass that suppress the movement of ions involved in leaching. Most waste glasses contain between 45-67 mol\% silica and thus have interconnected paths by which non-matrix forming elements can leach. These percolation channels do not occur in mineral (crystalline) structures, such as the FBSR products, as the silica network $+\mathrm{Si}-\mathrm{O}-\mathrm{Si}+$ groups suppress the movement of ions involved in leaching.

The percolation channels in glass (Figure 4) are defined by the SRO and MRO structure of a given glass, since glass has no LRO like mineral or crystalline waste forms. Hess [23] and Bottinga and Richet [24] developed polymerization models for simple and complex silicate glasses by invoking crystalline silicate structural analogues. Marians and Hobbs [25] developed a nomenclature scheme to describe the local topology surrounding the $\mathrm{SiO}_{4}$ anion groups in glass and their most immediate neighbors, "local clusters or quasicrystals." This enables higher order polymerization modeling of these local clusters into various types of rings, sub-networks, and networks that define the percolation channels. The polymerization scheme is similar in many aspects to the classification of silicate minerals into cyclosilicates (linkage of $\mathrm{SiO}_{4}$ tetrahedra into rings), sorosilicates (linkage of two $\mathrm{SiO}_{4}$ tetrahedra sharing an oxygen), ionsilicates (linkage of $\mathrm{SiO}_{4}$ tetrahedra into linear chains by the sharing of oxygen), etc.[26,27]

If glasses contain $\left(\mathrm{SiO}_{4}\right)^{-4},\left(\mathrm{BO}_{4}\right)^{-5},\left(\mathrm{BO}_{3}\right)^{-3}$ and some $\left(\mathrm{AlO}_{4}\right)^{-5}$ they are borosilicate glasses; if they contain $\left(\mathrm{SiO}_{4}\right)^{-4}$ and $\left(\mathrm{AlO}_{4}\right)^{-5}$ they are aluminosilicate glasses; if they contain only $\left(\mathrm{BO}_{4}\right)^{-}$ ${ }^{5},\left(\mathrm{BO}_{3}\right)^{-3}$ and some $\left(\mathrm{AlO}_{4}\right)^{-5}$ they are aluminoborate glasses; and if they contain $\left(\mathrm{PO}_{4}\right)^{-3}$ and $\left(\mathrm{AlO}_{4}\right)^{-5}$ they are aluminophosphate glasses, and so on, similar to the nomenclature for aluminosilicate minerals, borate minerals, and phosphate minerals. Glasses are metastable compared to crystalline minerals because crystalline species are at their lowest thermodynamic free energy.

Glasses do not have LRO and thus crystalline (mineral) waste forms are inherently more stable (at their lowest free energy state) than vitreous waste forms. [3,28,29] Many phase pure minerals have been made into vitreous (glassy) form by melting and quenching rapidly 
so the LRO crystalline structure cannot form. In 1998 experiments were performed at Lawrence Livermore National Laboratory (LLNL) on the mineral albite $\left(\mathrm{NaAlSi}_{3} \mathrm{O}_{8}\right)$ and on albite glass.[30] Figure 5 demonstrates that during Single Pass Flow Through (SPFT) testing the mineral dissolution is two orders of magnitude less than the mineral glass dissolution. The author states, "it is likely that same mechanisms are operating with both glasses and minerals but at different rates."

Another comparison of mineral durability to mineral glass durability of the same composition was performed by researchers at the Pennsylvania State University in 2001-2002 with the composition of albite $\left(\mathrm{NaAlSi}_{3} \mathrm{O}_{8}\right)$, a glass with the composition of jadeite $\left(\mathrm{NaAl}_{2} \mathrm{Si}_{2} \mathrm{O}_{8}\right)$, a glass with the composition of nepheline $\left(\mathrm{NaAlSiO}_{4}\right)$. [31,32] A durability comparison was made between these "mineral glasses" and the crystalline mineral of exactly the same composition. The durability response was found to be comparable over all $\mathrm{pH}$ ranges with respect to Si matrix dissolution.[31,32] When researchers at the Pacific Northwest National Laboratory (PNNL) performed Raman spectroscopy of nuclear waste glasses they determined that the glasses contained discrete $\mathrm{MRO}$ clusters of nepheline $\left[\mathrm{NaAlSiO}_{4}\right]$ and that these clusters or units had structures similar to crystalline nepheline. [20]

Water attacks the cations (contaminants) in the percolation channels in glass preferentially and then the covalent Si-O or Al-O bonds. Water attacks the cations (contaminants) in interstitial positions (non-framework positions where framework indicates tetrahedral and sometimes octahedral polyhedra) in minerals preferentially and then the covalent $\mathrm{Si}-\mathrm{O}$ or Al$\mathrm{O}$ bonds. Because of the similarity of the SRO and MRO in mineral (ceramic) and vitreous waste forms the dissolution mechanisms that attack the $\mathrm{Si}-\mathrm{O}$ and $\mathrm{Al}-\mathrm{O}$ bonds are similar and the mechanisms that attack the network breaking cations in glass (i.e. $\mathrm{Na}+$ ) and the interstitial cations (including the contaminants) in minerals (i.e. $\mathrm{Na}+$ ) are similar. However, the mineral waste forms can often afford better retention of the cationic species (including contaminants) compared to glass waste forms due to the LRO of the mineral structure and the regularity of the coordination and bonding associated with a coordination polyhedra in which a cation or radionuclide resides. The LRO provides shorter and more regular oxygen-cation (ionic) bonding and a periodic ordering (Figure $2 \mathrm{~b}$ compared to Figure 2a), which makes the contaminant retention in mineral/ceramic waste forms as good as glass and often better than glass. 
WSRC-STI-2008-00268

Revision 0

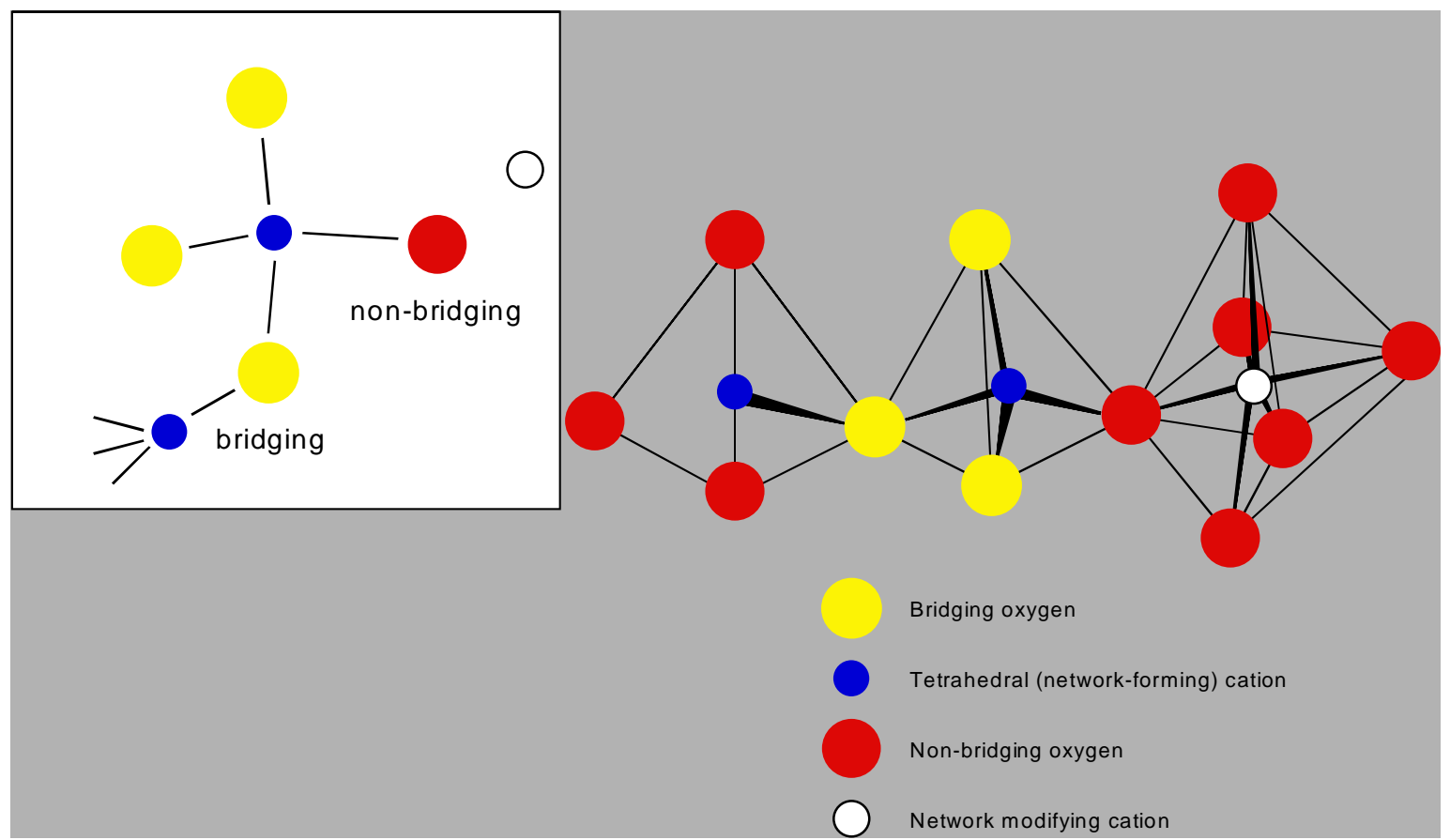

Figure 1. An example of short range order (SRO) structural units (tetrahedra and octahedra) in glass and mineral structures. Glass is a polymerized random structure of $\left(\mathrm{SiO}_{4}\right)^{-4},\left(\mathrm{AlO}_{4}\right)^{-5},\left(\mathrm{BO}_{4}\right)^{-5},\left(\mathrm{PO}_{4}\right)^{-3}$ tetrahedral and $\left(\mathrm{BO}_{3}\right)^{-3}$ trigonal structural units. Glasses possess SRO and Medium Range Order (MRO), but no long range order (LRO) structures like those that form the periodicity of the crystalline mineral phases. However, the SRO structures of crystalline and vitreous waste forms are the same basic structures. 


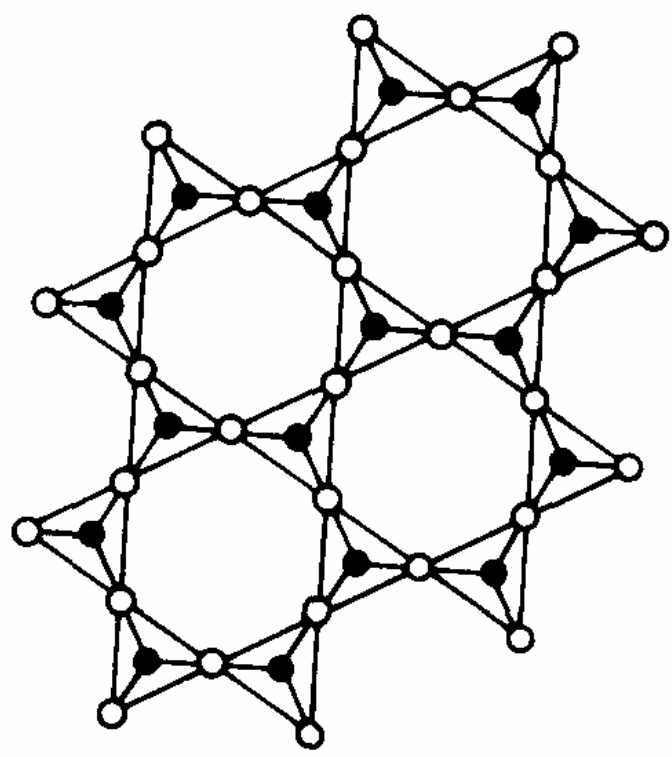

a)

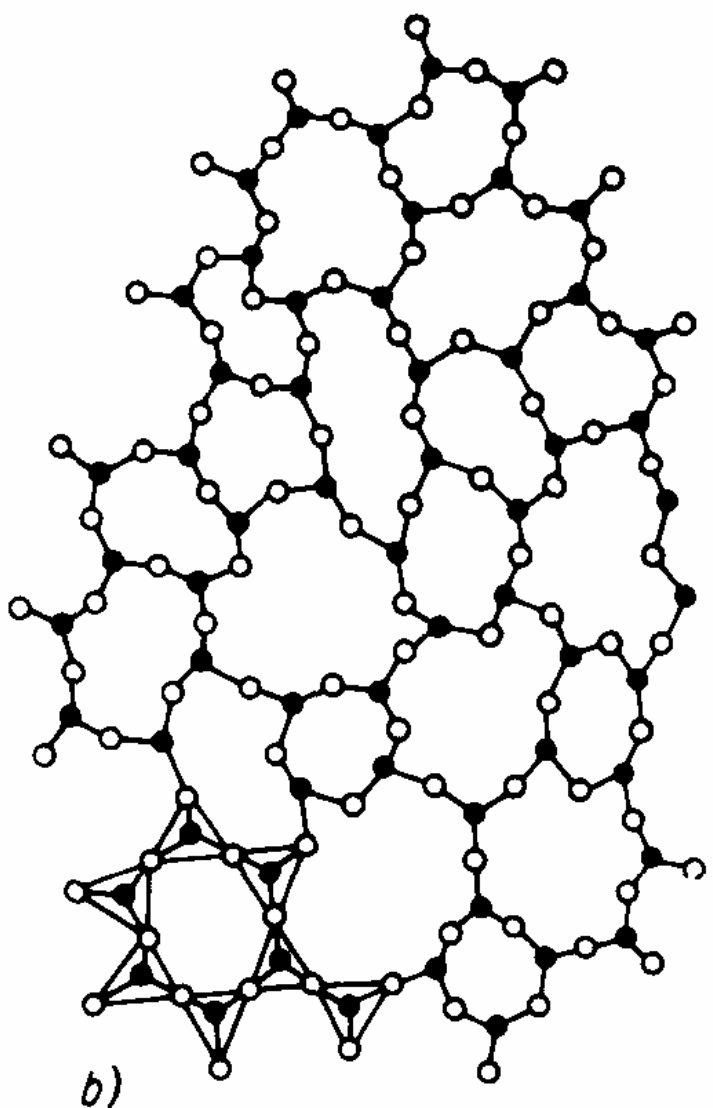

Figure 2. (a) Long range order of $\left(\mathrm{SiO}_{4}\right)^{-4}$ tetrahedra in crystalline $\mathrm{SiO}_{2}$. Only three oxygens appear in the 2-dimensional representation as the fourth oxygen is either above or below the 2-dimensional plane of the figure. (b) Polymerized structure with lack of long range order of $\left(\mathrm{SiO}_{4}\right)^{-4}$ tetrahedra in amorphous $\mathrm{SiO}_{2}$. From Vogel.[33] 


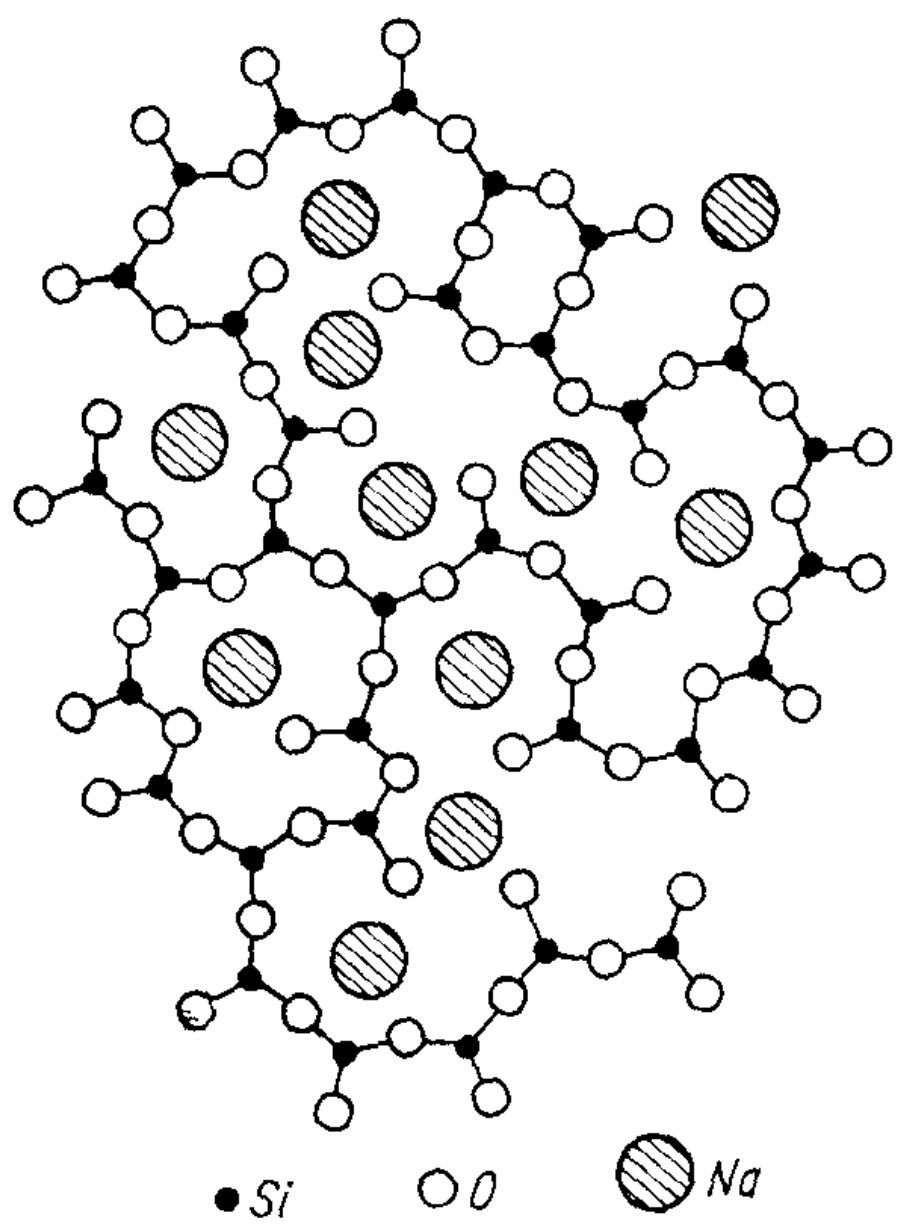

Figure 3. Atomic arrangement in a sodium silicate glass. Sodium cations are network breakers. Bridging oxygen atoms in pure $\mathrm{SiO}_{2}$ glass must rupture to accommodate the $\mathrm{Na}$ in these network breaking positions. The $\mathrm{Na}$ atoms are bonded to the nonbridging oxygen atoms ionically and thus many glass properties are controlled by the number of bridging to non-bridging oxygen bonds. As in the previous figure the open circles represent three of the four oxygen atoms around a given silicon atom and the fourth is either above or below the two dimensional structure shown. From Vogel.[33] 


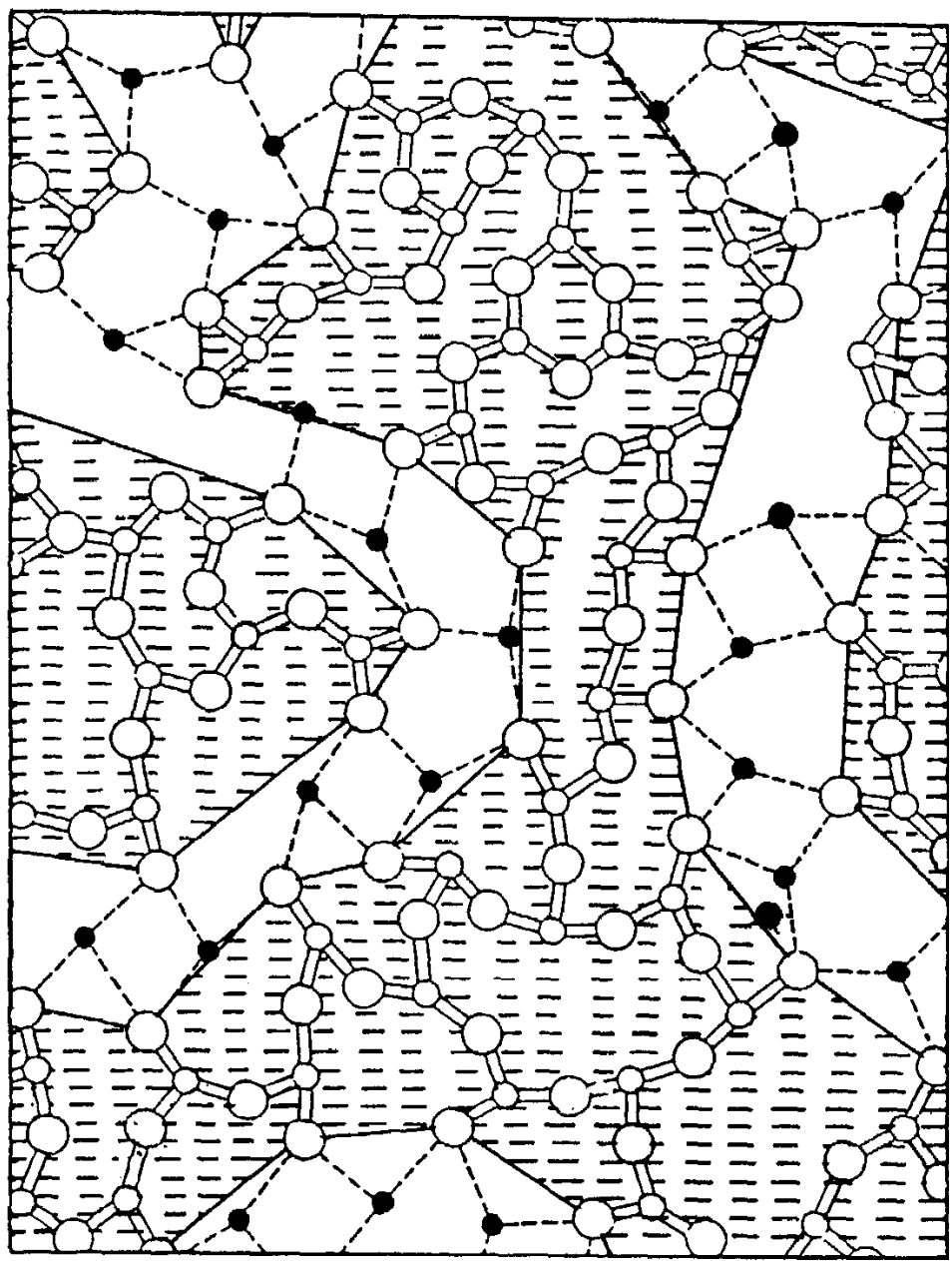

- Modifying Cations (M) $\bigcirc$ Network Formers (G) $\quad$ Oxygen atoms

Figure 4. A modified random network (MRN) for a glass of nominal composition $\mathrm{M}_{2} \mathrm{O}_{3}\left(\mathrm{G}_{2} \mathrm{O}_{3}\right)_{2}$, where $\mathrm{M}$ represents the modifying cations and $\mathrm{G}$ represents the tetrahedral cations. Covalent bonds are shown by the solid lines and ionic bonds by the dotted lines. The shaded regions are defined by the boundary which runs along the $\mathrm{G}-\mathrm{O}$ (i.e., non-bridging) bonds. The unshaded regions represent the percolation channels defined by the $\mathrm{M}-\mathrm{O}$ bonds that run through the glass network (from Greaves, 21). 
WSRC-STI-2008-00268

Revision 0

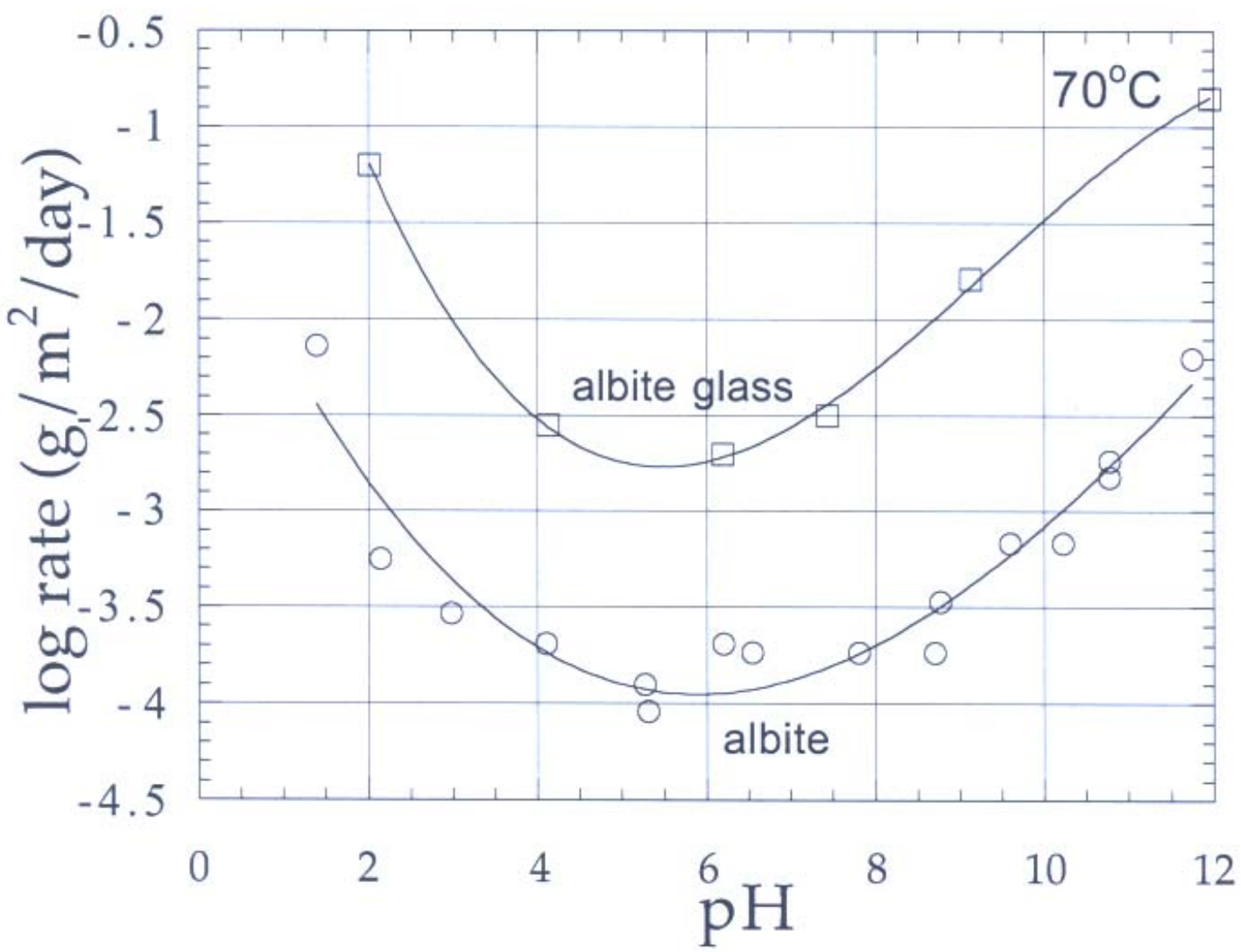

Figure 5. Comparison of dissolution rates of crystalline albite vs. albite glass from SPFT testing. [30] 


\subsection{THE FBSR MINERAL STRUCTURES: HOW THEY FORM AND HOW THE RADIONUCLIDES AND CONTAMINANTS ARE BOUND}

\subsection{The FBSR Mineral Phases}

The minerals that formed during FBSR processing of simulated AN-107 waste with kaolin clay are those given in Table I. These minerals are primarily feldspathoid group minerals, which includes sodalites, nosean, and nepheline. Additional phases formed from processing additives are spinels and corundum $\left(\mathrm{Al}_{2} \mathrm{O}_{3}\right)$. The spinels are formed from iron oxide added during processing. The $\mathrm{Al}_{2} \mathrm{O}_{3}$ present is from an $\mathrm{Al}_{2} \mathrm{O}_{3}$ startup bed.

Table I. Phases Identified by X-Ray Diffraction in FBSR Samples of Processed AN-107

\begin{tabular}{|c|c|}
\hline Mineral Phases Identified by TTT [34] & Mineral Phases Identified by SRNL[34] \\
\hline \multicolumn{2}{|l|}{ Feldspathoid Minerals } \\
\hline$\left[\mathrm{NaAlSiO}_{4}\right]_{6} \mathrm{Na}_{2}\left(\mathrm{SO}_{4}\right)$ (Nosean-Sodalite) & {$\left[\mathrm{NaAlSiO}_{4}\right]_{6} \mathrm{Na}_{2}\left(\mathrm{SO}_{4}\right)$ (Nosean-Sodalite) } \\
\hline $\mathrm{NaAlSiO}_{4}$ (Nepheline) & $\mathrm{NaAlSiO}_{4}($ Nepheline $)$ \\
\hline \multicolumn{2}{|l|}{ Spinel Minerals } \\
\hline \multirow[t]{2}{*}{$\mathrm{Fe}_{2} \mathrm{O}_{3}$ (Hematite) } & $\mathrm{Fe}_{2} \mathrm{O}_{3}$ (Hematite) \\
\hline & $\mathrm{Fe}_{3} \mathrm{O}_{4}$ (Magnetite) \\
\hline \multicolumn{2}{|l|}{ Startup Bed Material } \\
\hline $\mathrm{Al}_{2} \mathrm{O}_{3}$ (Corundum) & $\mathrm{Al}_{2} \mathrm{O}_{3}$ (Corundum) \\
\hline
\end{tabular}

The FBSR technology uses the feldspathoid alkali aluminosilicate (NAS) host phases to accommodate the waste species as did the supercalcine [35] high temperature ceramics investigated for HLW waste disposal $>25$ years ago (see Table II). Similar silicate mineral phases (sodalite) are also formed in the glass-bonded sodalite ceramic waste form (CWF) for stabilization of chlorides and iodides from electrorefiner wastes from the EBR II fast breeder reactor (Table II).

The feldspathoid mineral, sodalite, was a minor mineral phase in the supercalcine mineral assemblages for HLW. During investigation of the sodalite phase it was found to incorporate $\mathrm{Cs}$, Sr, and Mo into the structure, e.g. Mo as $\left(\mathrm{NaAlSiO}_{4}\right)_{6}\left(\mathrm{NaMoO}_{4}\right)_{2}$.[36] The Cs and $\mathrm{Sr}_{0.5}$ substituted for $\mathrm{Na}$, while the Mo complexed with $\mathrm{Na}$ in the cage like structure. Additional sodalites have been known since 1892 [37] that retain monovalent anions such as Br or I as $\mathrm{NaBr}$ or $\mathrm{NaI}$ in the cage structure, while higher valent anionic groups such as $\mathrm{AsO}_{4}{ }^{3-}$ and $\mathrm{CrO}_{4}{ }^{2-}$ form $\mathrm{Na}_{2} \mathrm{XO}_{4}$ groups in the cage structure where $\mathrm{X}=\mathrm{Cr}, \mathrm{Se}, \mathrm{W}, \mathrm{P}, \mathrm{V}$, and As. Each individual cation inside the cage is ionically bonded to the NBO that form the cage and to the other cations in the $\mathrm{Na}_{2} \mathrm{XO}_{4}$ structure. By 1945 additional sodalites containing $2 \mathrm{NaF}, \mathrm{Na}_{2} \mathrm{~S}$, $2 \mathrm{NaMnO}_{4}$ had been made.[37] In 2000, the structure of the sodium borate sodalite, $\left(\mathrm{NaAlSiO}_{4}\right)_{6}\left(\mathrm{NaBO}_{4}\right)_{2}$, was determined.[38] In 2004 a $2 \mathrm{NaReO}_{4}$ containing sodalite had been made phase pure and shown to be isostructural with the $2 \mathrm{NaMnO}_{4}$ sodalite. In the perrhennate sodalite, e.g. two $\mathrm{NaReO}_{4}$, occupy the cage structure of the Re sodalite.[39] In this mineral, the $\mathrm{Re}$ is a surrogate for radioactive $\mathrm{Tc}^{99}$, implying that a $2 \mathrm{NaTcO}_{4}$ sodalite can be stable mineral phase. 
Table II. Similarity of Mineral Phases in FBSR Waste Forms to Other HLW/LAW Waste Forms

\begin{tabular}{|c|c|c|}
\hline $\begin{array}{l}\text { FBSR Mineral Phases } \\
\text { Formed at } \sim 700^{\circ} \mathrm{C}[34]\end{array}$ & $\begin{array}{c}\text { Mineral Phases } \\
\text { Formed in High } \\
\text { Temperature HLW } \\
\text { Ceramic Waste Forms }\end{array}$ & $\begin{array}{c}\text { Mineral Phases in ANL } \\
\text { Glass Bonded Sodalite } \\
\text { Ceramic Waste Forms } \\
{[40,41,42]}\end{array}$ \\
\hline $\begin{array}{l}\text { Nosean (Sodalite Family) } \\
{\left[\mathrm{NaAlSiO}_{4}\right]_{6} \mathrm{Na}_{2}\left(\mathrm{SO}_{4}\right)}\end{array}$ & \begin{tabular}{|l|} 
Sodalite \\
{$\left[\mathrm{NaAlSiO}_{4}\right]_{6}\left(\mathrm{NaMoO}_{4}\right)_{2}$}
\end{tabular} & $\begin{array}{l}\text { Sodalite } \\
{\left[\mathrm{NaAlSiO}_{4}\right]_{6}(\mathrm{NaCl})_{2}}\end{array}$ \\
\hline Nepheline $\mathrm{NaAlSiO}_{4}$ & Nepheline $\mathrm{NaAlSiO}_{4}$ & Nepheline $\mathrm{NaAlSiO}_{4}$ \\
\hline Corundum $\mathrm{Al}_{2} \mathrm{O}_{3}$ & Corundum $\mathrm{Al}_{2} \mathrm{O}_{3}$ & $\mathrm{NaCl}$ \\
\hline Hematite $\mathrm{Fe}_{2} \mathrm{O}_{3}$ & & $\mathrm{PuO}_{2}$ \\
\hline
\end{tabular}

\subsection{How the FBSR Mineral Structures Form: Nanoscale Reactions}

The FBSR technology takes advantage of the nano-scale properties of clay as a waste forming additive. Clay becomes amorphous at the moderate operating temperatures of the FBSR process $\left(700-750^{\circ} \mathrm{C}\right)$ when the hydroxyl atoms are driven out of the clay structure. While the clay does not melt at the operating temperature, the clay structure becomes unstable once it looses the hydroxyl atoms. Thus, the remaining cations in the clay ( $\mathrm{Si}$ and Al) are unstable on the nano-scale and very reactive, e.g. they complex immediately with waste species to form stable new mineral phases by solid state reaction. There is no liquid (molten) phase in FBSR processing, as this would compromise the fluidization and thus no fractionation of radionuclides to a molten phase intergranular phase as with HIPing or sintering. FBSR mineralization occurs in the presence of steam, which lowers reaction temperatures by increasing the effective surface area of the reacting components. $[43,44]$

Mineralization of clay plus waste occurs because the moderate FBSR operating temperature is in the range in which most clays become amorphous at the nanoscale level, e.g. kaolin, bentonite (montmorillonite), and illite clays become amorphous at $\geq 550^{\circ} \mathrm{C}$. In clays, like many other oxide minerals and glass, the $\mathrm{Si}$ is tetrahedral as $\left(\mathrm{SiO}_{4}\right)^{-4}$. However, in kaolin clays the $\mathrm{Al}$ atom is octahedrally coordinated (6 nearest neighboring atoms that form an octhedra) with 2 oxygen atoms and four hydroxyl $\left(\mathrm{OH}^{-}\right)$atoms instead of by six oxygen atoms (see Figure 6). In other clays (bentonites and illites) the $\mathrm{Al}$ atom is also octahedrally coordinated by 4 oxygen atoms and two hydroxyl $\left(\mathrm{OH}^{-}\right)$atoms. In bentonite (montmorillonite) waters of hydration occupy the interlayer sites as well, while in illites potassium atoms occupy the interlayer sites (Figure 6).

The clays lose their hydroxyl groups at the FBSR temperatures, which destabilizes the octahedral $\mathrm{Al}^{3+}$ cation in their structure (Figure 6). Once the $\mathrm{Al}^{3+}$ cation is destabilized the clay becomes amorphous and this can be verified by X-ray diffraction (XRD) analysis, which does not exhibit any crystallographic Bragg reflections. The alkali elements (e.g., Na, K, and $\mathrm{Cs}$ ) in the waste "alkali activate" the unstable $\mathrm{Al}^{3+}$ cation to form new mineral phases and the 
fluidizing agent, steam, catalyzes the mineralization. In the absence of steam many of these mineral phases would only form at temperatures of $1200-1500^{\circ} \mathrm{C}$.[34]

The "alkali activation" of aluminosilicates, including kaolin clay, is a patented method by which Linde Zeolite-A, [NaAlSiO$]_{12} \bullet 27 \mathrm{H}_{2} \mathrm{O}$, is formed.[45] The formation of Zeolite-A is well studied and very rapid kinetically. The Zeolite-A structure can form (1) from a hydrogel process where the reactants are reactive oxides, soluble silicates, and soluble aluminates in a caustic solution; (2) from conversion of clay minerals (specifically kaolin and meta-kaolin ${ }^{\S}$ ) in the presence of soluble silicates and caustic; or (3) by reaction of silica sols, natural $\mathrm{SiO}_{2}$, amorphous minerals, and volcanic glass in the presence of caustic. [45] Formation can occur at temperatures as low as $85-110^{\circ} \mathrm{C}$ at $\mathrm{pH}$ values $\geq 10$ in 2 or 3 hours (crystallization is more rapid in the presence of excess $\mathrm{NaOH}$ ). [46,47] Formation of zeolites from kaolinites at $80^{\circ} \mathrm{C}$ were made by adding solutions of $\mathrm{CsOH}, \mathrm{RbOH}, \mathrm{KOH}, \mathrm{NaOH}$ and/or $\mathrm{LiOH}$.[48]

The structure of Zeolite-A is shown in Figure 7a. It can be seen that the Si and Al atoms that are in tetrahedral coordination are linked together to form cages and channels between the cages. In Zeolite-A these cages are normally vacant and Zeolite-A is a double unit cell of the sodalite structure shown in Figure 7b. However, the sodalite structure does not have the inter-cage channels (Figure 7b) that Zeolite-A has. Zeolite-A has the same alumina:silica ratio and ordering as the sodalite group of minerals listed in Table III, but the cage is vacant.

It should be noted that the negatively charged $\mathrm{NBO}$ of the $\left(\mathrm{AlO}_{4}\right)^{-5}$ and $\left(\mathrm{SiO}_{4}\right)^{-4}$ tetrahedra that are arranged together to form the cage structure, protrude both inside and cover the outside of the cage structures. This enables the cations in the $\mathrm{Na}_{2} \mathrm{SO}_{4}$ and/or $\mathrm{NaReO} 4$ to bond to multiple NBO's protruding inside the cage and to other cations outside the cage such as $\mathrm{Cs}^{+}, \mathrm{Ca}^{2+}, \mathrm{Sr}^{2+}$ etc. The mineral name indicates what species are bonded in the cage structure (given in parentheses in Table III) and that the cage is composed of $\left[\mathrm{NaAlSiO}_{4}\right]_{6}$ (given in square brackets in Table III). Minerals that tolerate mixed $\mathrm{Ca} / \mathrm{Na}$ with $\mathrm{SO}_{4} / \mathrm{S}$ and $\mathrm{Cl}$ are hauyne and lazurite, indicating that other alkali elements can substitute for $\mathrm{Na}$, e.g. Cs, $\mathrm{K}$, Li [49] and varying alkaline earths can substitute for calcium, e.g. strontium, barium [49]. Sodalite minerals are known to accommodate Be in place of $\mathrm{Al}$ and $\mathrm{S}_{2}$ in the cage structure, along with $\mathrm{Fe}, \mathrm{Mn}$, and $\mathrm{Zn}$, e.g. helvite $\left(\mathrm{Mn}_{4}\left[\mathrm{Be}_{3} \mathrm{Si}_{3} \mathrm{O}_{12}\right] \mathrm{S}\right)$, danalite $\left(\mathrm{Fe}_{4}\left[\mathrm{Be}_{3} \mathrm{Si}_{3} \mathrm{O}_{12}\right] \mathrm{S}\right)$, and genthelvite $\left(\mathrm{Zn}_{4}\left[\mathrm{Be}_{3} \mathrm{Si}_{3} \mathrm{O}_{12}\right] \mathrm{S}\right)$. [50] These cage-structured sodalites are also found to retain Mo, Cs, and Sr, B, Ge, I and Br.[50,51,52] Regardless of the oxidation state of sulfur during processing, the feldspathoid minerals can accommodate sulfur as either sulfate or sulfide. Although neither Cs nor Rb sodalites have been identified as phase pure end members, but $\mathrm{Cs}$ and $\mathrm{Rb}$ are tolerated in the sodalite structure.[49,50] In addition, Zeolite-A structures are known to form from reaction of $\mathrm{CsOH}$ and $\mathrm{RbOH}$ with kaolin clay as discussed above. [48]

\footnotetext{
$\S$ metakaolin is kaolin that has been heat treated to $\geq 550^{\circ} \mathrm{C}$ to make it amorphous.
} 


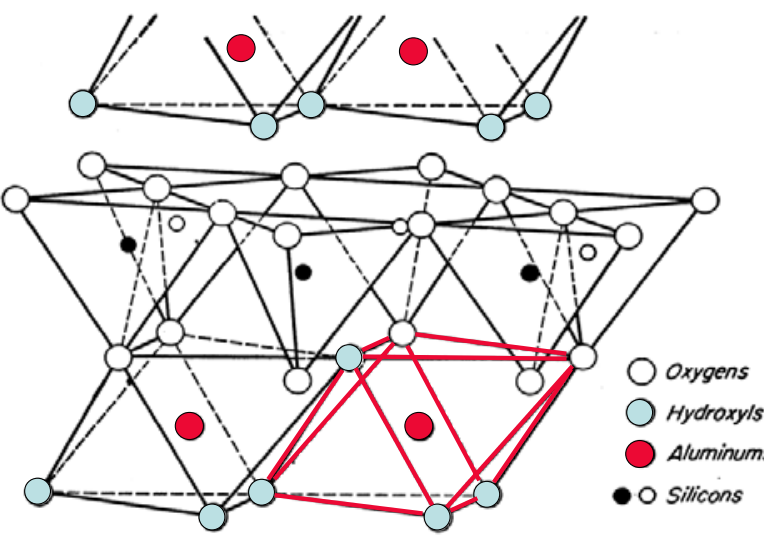

Kaolin Clay
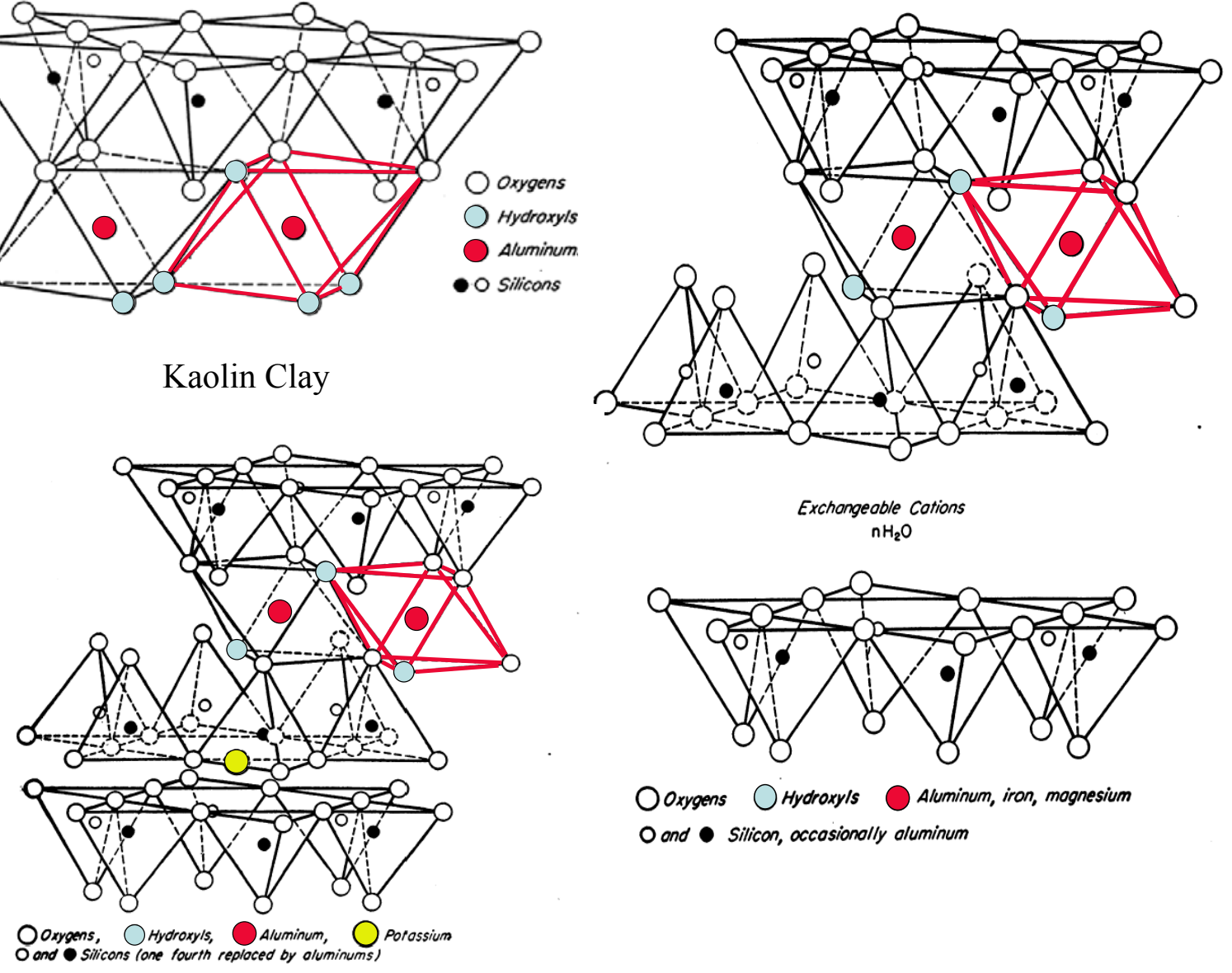

Illite

Bentonite/Montmorillonite

Figure 6. Atomic structures of various clays (kaolin, bentonite-montmorillonite, illite). After Grim [53,54]. 


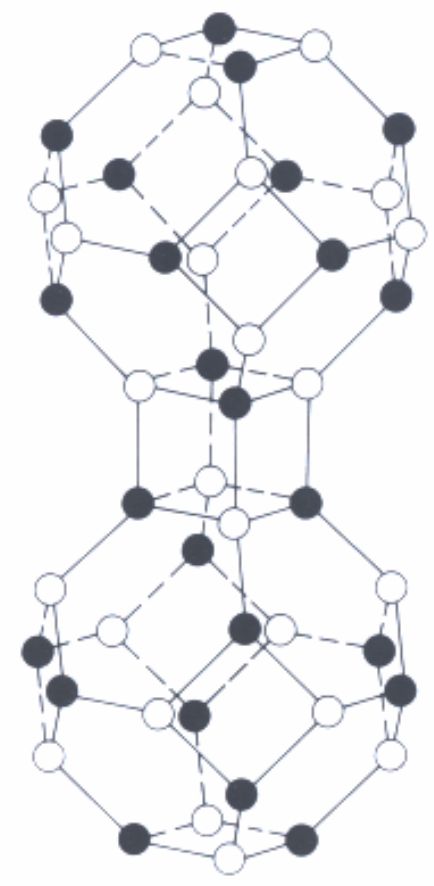

(a) Zeolite-A

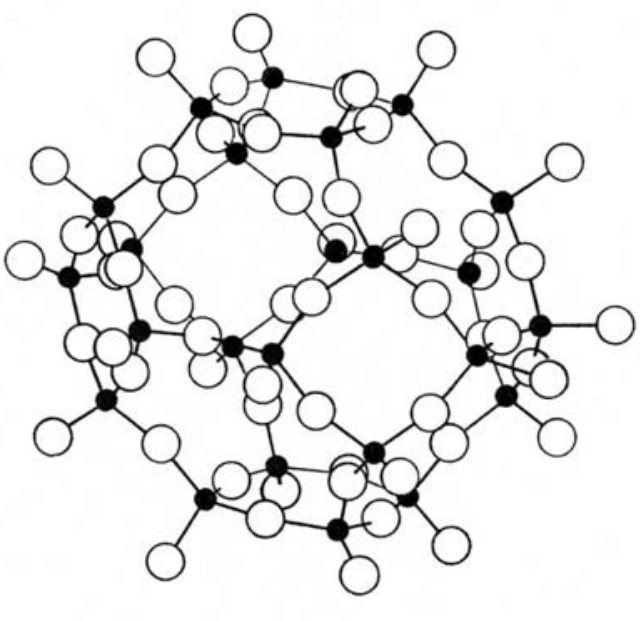

- $\mathrm{Si}, \mathrm{Al} \bigcirc$ oxygen

Figure 7. (a) Structure of Zeolite-A [37] showing alternate Al and Si atom ordering but omitting the tetrahedral oxygens around each $\mathrm{Al}$ and $\mathrm{Si}$; (b) Structure of Sodalite showing the tetrahedral oxygens (bridging and non-bridging) around each Al and $\mathrm{Si}$ but omitting the $\mathrm{Al}$ and $\mathrm{Si}$ atom ordering. [50] 
Table III. Structurally Related Zeolite-A and Cubic Sodalite Phases

\begin{tabular}{|c|c|c|c|c|}
\hline Cage Occupancy & Chemical Formula & Mineral & $\begin{array}{l}\text { Density } \\
\left(\mathrm{g} / \mathrm{cm}^{3}\right)\end{array}$ & Ref. \\
\hline \multicolumn{5}{|l|}{ Precursor } \\
\hline NONE & {$\left[\mathrm{Na}_{12} \mathrm{Al}_{12} \mathrm{Si}_{12} \mathrm{O}_{48}\right] \cdot 27 \mathrm{H}_{2} \mathrm{O}$} & Zeolite-A & 1.99 & 55,46 \\
\hline \multicolumn{5}{|l|}{ Sodalite Group } \\
\hline $2 \mathrm{NaCl}$ & {$\left[\mathrm{Na}_{6} \mathrm{Al}_{6} \mathrm{Si}_{6} \mathrm{O}_{24}\right](2 \mathrm{NaCl})$} & Sodalite & $2.31^{*}$ & 50 \\
\hline $2 \mathrm{NaOH}$ & {$\left[\mathrm{Na}_{6} \mathrm{Al}_{6} \mathrm{Si}_{6} \mathrm{O}_{24}\right](2 \mathrm{NaOH}) \bullet 1.5 \mathrm{H}_{2} \mathrm{O}$} & $\begin{array}{c}\text { Basic Sodalite } \\
\text { or Hydroxy- } \\
\text { sodalite }\end{array}$ & $2.215^{* *}$ & 56 \\
\hline $2 \mathrm{NaNO}_{3}$ & {$\left[\mathrm{Na}_{6} \mathrm{Al}_{6} \mathrm{Si}_{6} \mathrm{O}_{24}\right]\left(2 \mathrm{NaNO}_{3}\right)$} & $\begin{array}{l}\text { Nitrated } \\
\text { Sodalite }\end{array}$ & 2.342 & $\begin{array}{c}\mathrm{PDF}^{f} \\
\# 50-0248\end{array}$ \\
\hline $\mathrm{Na}_{2} \mathrm{SO}_{4}$ & {$\left[\mathrm{Na}_{6} \mathrm{Al}_{6} \mathrm{Si}_{6} \mathrm{O}_{24}\right]\left(\mathrm{Na}_{2} \mathrm{SO}_{4}\right)$} & Nosean & $2.21^{\mathrm{tt}}$ & 57 \\
\hline $\mathrm{xNaOH}+\mathrm{y} \mathrm{H}_{2} \mathrm{O}$ & {$\left[\mathrm{Na}_{6} \mathrm{Al}_{6} \mathrm{Si}_{6} \mathrm{O}_{24}\right](\mathrm{xNaOH}) \bullet y \mathrm{H}_{2} \mathrm{O}$} & Basic Nosean & & 56 \\
\hline $1-2(\mathrm{Ca}, \mathrm{Na}) \mathrm{SO}_{4}$ & {$\left[\mathrm{Na}_{6} \mathrm{Al}_{6} \mathrm{Si}_{6} \mathrm{O}_{24}\right]\left((\mathrm{Ca}, \mathrm{Na}) \mathrm{SO}_{4}\right)_{1-2}{ }^{\mathrm{t}}$} & Hauyne & $2.4^{\mathrm{t}}$ & 57 \\
\hline $\mathrm{x}(\mathrm{Ca}, \mathrm{Na})\left(\mathrm{S}, \mathrm{SO}_{4}, \mathrm{Cl}\right)$ & {$\left[(\mathrm{Ca}, \mathrm{Na})_{6} \mathrm{Al}_{6} \mathrm{Si}_{6} \mathrm{O}_{24}\right]\left((\mathrm{Ca}, \mathrm{Na}) \mathrm{S}, \mathrm{SO}_{4}, \mathrm{Cl}\right)_{\mathrm{x}}{ }^{\mathrm{t}}$} & Lazurite & 2.43 & $\begin{array}{c}\mathrm{PDF}^{f} \\
\# 17-749\end{array}$ \\
\hline $\mathrm{Na}_{2} \mathrm{MoO}_{4}$ & {$\left[\mathrm{Na}_{6} \mathrm{Al}_{6} \mathrm{Si}_{6} \mathrm{O}_{24}\right]\left(\mathrm{Na}_{2} \mathrm{MoO}_{4}\right)$} & Mo Sodalite & & 36 \\
\hline $2 \mathrm{NaReO}_{4}$ & {$\left[\mathrm{Na}_{6} \mathrm{Al}_{6} \mathrm{Si}_{6} \mathrm{O}_{24}\right]\left(\mathrm{NaReO}_{4}\right)_{2}$} & Re Sodalite & & 39 \\
\hline
\end{tabular}

${ }^{f} \mathrm{PDF}=$ Powder Diffraction File

t PDF \#20-1087

* PDF \# 20-495

\$PDF \#11-0590 and \#38-241

tt PDF \#17-538

** PDF \#11-401 


\subsection{Bonding of Radionuclides and Contaminants}

The flexibility of the sodalite structure as shown in Figure 8 and discussed in conjunction with Table III demonstrates that monovalent species such as $\mathrm{Cs}^{+}, \mathrm{K}^{+}, \mathrm{Ca}_{0.5}, \mathrm{Sr}_{0.5}$, etc. can substitute for $\mathrm{Na}^{+}$in the sodalite family of structures, while $\left(\mathrm{SO}_{4}\right)^{-2},\left(\mathrm{MoO}_{4}\right)^{-2},\left(\mathrm{AsO}_{4}\right)^{-2}$, $\left(\mathrm{MnO}_{4}\right)^{-1}$, and $\left(\mathrm{ReO}_{4}\right)^{-1}$ [and presumably $\left(\mathrm{TcO}_{4}\right)^{-1}$ ], can all substitute for the $\mathrm{Cl}$ atoms in the sodalite structure as shown in Figure 8, Figure 12, and Figure 13. For elements such as $\mathrm{S}$, $\mathrm{Mo}, \mathrm{Re}(\mathrm{Tc})$ and $\mathrm{Mn}$ the oxygens in tetrahedral polyhedra around these elements provide the oxygen bonds for the tetrahedral $\mathrm{XO}_{4}$ groups. These oxygen come from four of the six tetrahedra forming a ring along the body diagonal of the cubic unit cell.[58] In addition, $\mathrm{I}^{-}$, $\mathrm{Br}^{-}, \mathrm{OH}^{-}$, and $\mathrm{NO}_{3}^{-2}$ can all substitute for the $\mathrm{Cl}^{-}$atoms in the sodalite structure. Boron and beryllium can substitute for Al in a tetrahedral polyhedra in the sodalite structures as can titanium while elements like iron and zinc substitute for $\mathrm{Na}^{+} .[49,58]$

All bonding in the sodalite/nosean single unit cell shown in Figure 12 is ionic and the atoms are regularly arranged. This is similar to the manner of ionic bonding in glass, but more highly ordered than the atomic arrangements in glass (shown in Figure 12 for comparison). For example, the sodium atoms in sodalite are tetrahedrally coordinated and bound ionically to one $\mathrm{Cl}^{-}$(or substitutes as discussed above and shown in Figure 8c) and bound ionically to three non-bridging oxygens from the framework $\left(\mathrm{AlO}_{4}\right)^{-5}$ and $\left(\mathrm{SiO}_{4}\right)^{-4}$. In glass, sodium atoms are only loosely bound in cavities between the framework $\left(\mathrm{AlO}_{4}\right)^{-5}$ and $\left(\mathrm{SiO}_{4}\right)^{-4}$ and loosely surrounded by 10 or 12 oxygen atoms. A comparison of the sodalite structure and glass is shown in Figure 12 for the bonding of Cs, S, Mo and likely Re/Tc. The position of $\mathrm{I}^{-}$ and $\mathrm{Cl}^{-}$in glass is poorly understood and not discussed in this comparison.

Figure 9 demonstrates that many of the same alkali and alkaline earth substitutions that occur in sodalite can occur in the 8 and 9 coordinated ring sites in nepheline. As discussed in the previous section, the ring structures in nepheline are similar to the ring structures in the sodalites that define the cage structures in the sodalites and Zeolite-A. Nepheline can be a host mineral for other alkali or alkaline earth elements $\left(\mathrm{Cs}, \mathrm{K}, \mathrm{Ca}_{0.5}\right)$ substituting for $\mathrm{Na}^{+}$, while rare earth elements substitute for $\mathrm{Al}^{3+}$.[49] Iron, $\mathrm{Ti}^{3+}, \mathrm{Mn}, \mathrm{Mg}, \mathrm{Ba}, \mathrm{Li}, \mathrm{Rb}, \mathrm{Sr}, \mathrm{Zr}, \mathrm{Ga}$, $\mathrm{Cu}, \mathrm{V}$, and $\mathrm{Yb}$ all substitute in trace amounts in the nepheline lattice.[49] In addition, $\mathrm{BaAl}_{2} \mathrm{O}_{4}, \mathrm{SrAl}_{2} \mathrm{O}_{4},(\mathrm{Sr}, \mathrm{Ba}) \mathrm{Al}_{2} \mathrm{O}_{4}, \mathrm{RbAlSiO}_{4}, \mathrm{CsAlSiO}_{4}$, and $\mathrm{KFeSiO}_{4}$ all have nepheline/kalsilite structures with similar ring structures.[49] The structures of two of these $\left(\mathrm{CsAlSiO}_{4}\right.$ and $\left.\mathrm{RbAlSiO}_{4}\right)$ are shown in Figure 10. 
The nephelines are nominally $\mathrm{NaAlSiO}_{4}$ or $\mathrm{Na}_{3} \mathrm{KAl}_{4} \mathrm{Si}_{4} \mathrm{O}_{16}$ which is $1 / 6$ or $2 / 3$ of the unit cell of the sodalite cage structure given as $\left[\mathrm{Na}_{6} \mathrm{Al}_{6} \mathrm{Si}_{6} \mathrm{O}_{24}\right]$ in Table III or $1 / 12$ and $1 / 3$ of the unit cell of the Zeolite- $\mathrm{A}$ double cage structure $\left[\mathrm{Na}_{12} \mathrm{Al}_{12} \mathrm{Si}_{12} \mathrm{O}_{48}\right]$. This is because six and four membered rings of tetrahedra define the cage structures in the sodalites and Zeolite-A. Thus, the aluminosilicate framework of both sodalite and Zeolite-A are related to the structure of nepheline and made by similar nanostructure reaction with destabilized kaolin. Leaching of the nepheline framework, in terms of the degradation of the matrix elements of $\mathrm{Al}$ and $\mathrm{Si}$ should be similar to the leaching of the other sodalite minerals as the framework structure, $\left[\mathrm{Na}_{6} \mathrm{Al}_{6} \mathrm{Si}_{6} \mathrm{O}_{24}\right]$, is the same. This will be discussed in Section 4.2.

Nepheline is a hexagonal structured feldspathoid mineral. The ring structured aluminosilicate framework of nepheline forms cavities within the framework (Figure 9). There are eight large coordination sites that bond $\mathrm{Ca}, \mathrm{K}$, and $\mathrm{Cs}$ ionically to nine framework (A1,Si tetrahedral) oxygens and six smaller coordination sites that bond $\mathrm{Na}$ ionically to eight framework (A1,Si tetrahedral) oxygens.[50] The larger nine-fold sites can hold large cations such as $\mathrm{Cs}, \mathrm{K}$, and $\mathrm{Ca}$ while the smaller sites accommodate the $\mathrm{Na}$ (Figure 9). The $\mathrm{K}$ nepheline is known as kalsilite $\left(\mathrm{KAlSiO}_{4}\right)$. In nature, the nepheline structure is known to accommodate $\mathrm{Fe}$, $\mathrm{Ti}$ and $\mathrm{Mg}$ as well.[50] In addition, rare earth nephelines are known, e.g. $\mathrm{NaYSiO}_{4}, \mathrm{Ca}_{0.5} \mathrm{YSiO}_{4}, \mathrm{NaLaSiO}_{4}, \mathrm{KLaSiO}_{4}, \mathrm{NaNdSiO}_{4}, \mathrm{KNdSiO}_{4}$, and $\mathrm{Ca}_{0.5} \mathrm{NdSiO}_{4}$, where the rare earth substitutes for Al in the structure.[37]

A sodium rich cubic structured nepheline with excess $\mathrm{Na}$ is also known, e.g. $\left(\mathrm{Na}_{2} \mathrm{O}\right)_{0.33}$ $\mathrm{Na}\left[\mathrm{AlSiO}_{4}\right]$ and was found in the AN-107 FBSR mineralized product. This nepheline structure has large cage like voids in the structure where the Na can bond ionically to 12 framework oxygens.[59] This cage structured nepheline is not known to occur in nature, but the large cage-like voids should be capable of retaining large radionuclides, especially monovalent radionuclides such as $\mathrm{Cs}$. Likewise, $\mathrm{Na}_{2} \mathrm{O}$ deficient nepheline structures are known (Figure 11) that have been found in other FBSR mineralizing campaigns for INL's alumina rich Sodium Bearing Waste (SBW).

The spinels such as $\mathrm{Fe}_{3} \mathrm{O}_{4}\left(\mathrm{Fe}^{+2} \mathrm{Fe}_{2}^{+3} \mathrm{O}_{4}\right)$ are known to take $\mathrm{Cr}^{+3}$ and $\mathrm{Ti}^{+3}$ into their lattice in place of $\mathrm{Fe}^{+3}$, and many of the divalent transition metals like $\mathrm{Ni}^{2+}, \mathrm{Mn}^{2+}, \mathrm{Zn}^{2+}, \mathrm{Mg}^{2+}$ into their lattice as well [60]. Spinels have both tetrahedral and octahedral coordination spheres with oxygen. The trivalent ions reside in the four-fold coordination positions and the divalent ions reside in the six-fold coordination positions. All the trivalent and divalent ions are ionically bonded to oxygen. 


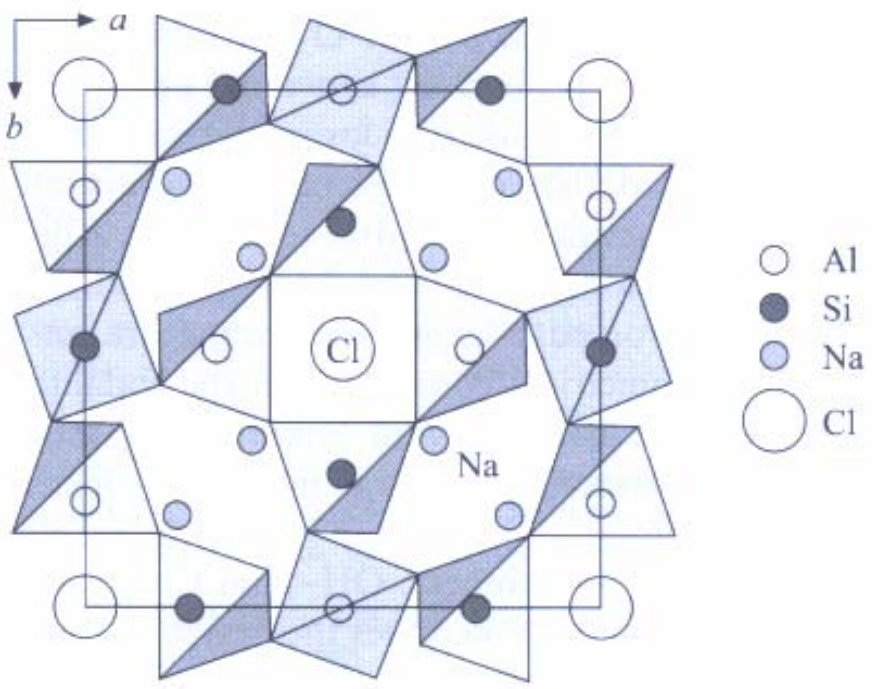

(a)

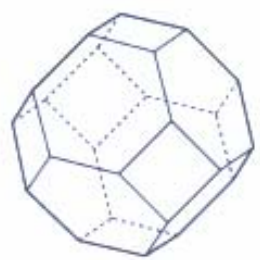

(b)

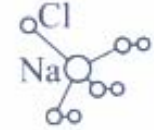

(c)

Figure 8. Structure of Sodalite showing (a) two-dimensional projection of the (b) threedimensional structure and (c) the four fold ionic coordination of the $\mathrm{Na}$ site to the $\mathrm{Cl}^{-}$ion and three framework oxygen bonds. [49] 
WSRC-STI-2008-00268

Revision 0
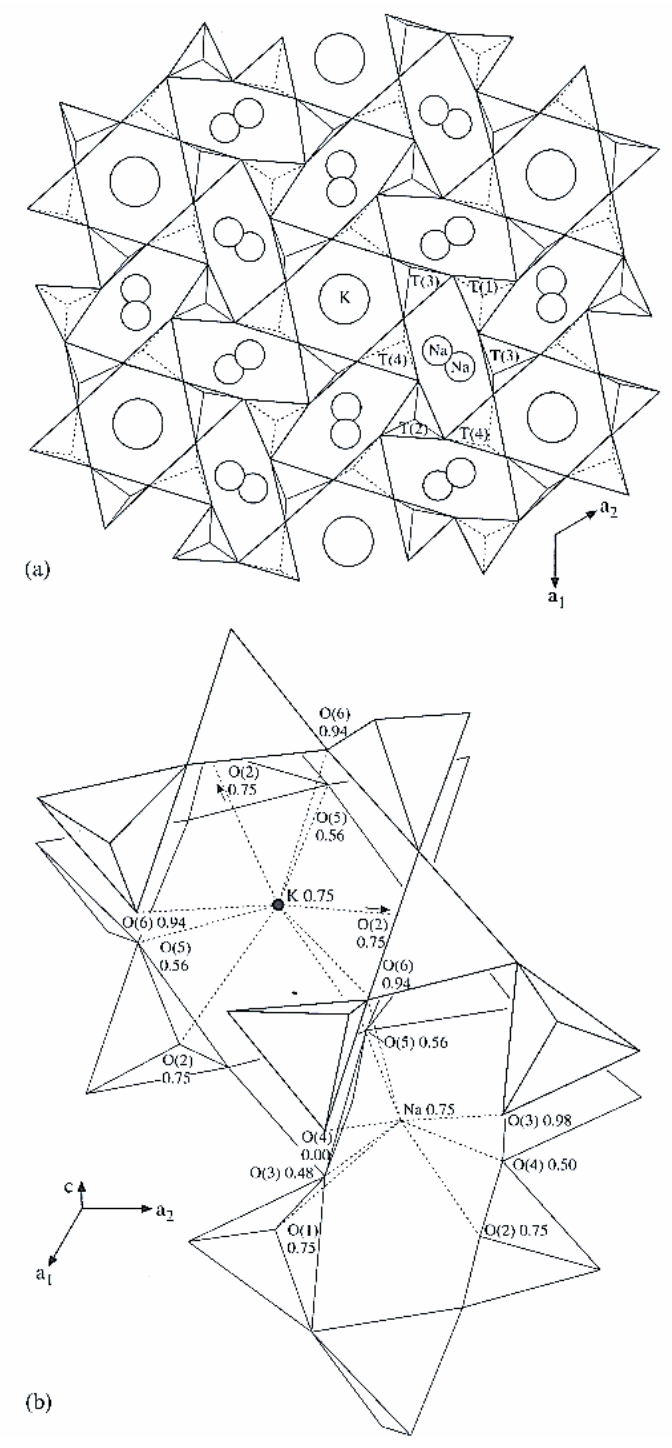

Figure 9. Two-dimensional representation of the structure of nepheline showing the smaller 8 oxygen sites that are occupied by $\mathrm{Na}$ and the larger 9 oxygen sites that are occupied by $\mathrm{K}$ and larger ions such as $\mathrm{Cs}$ and $\mathrm{Ca}$. [49] 

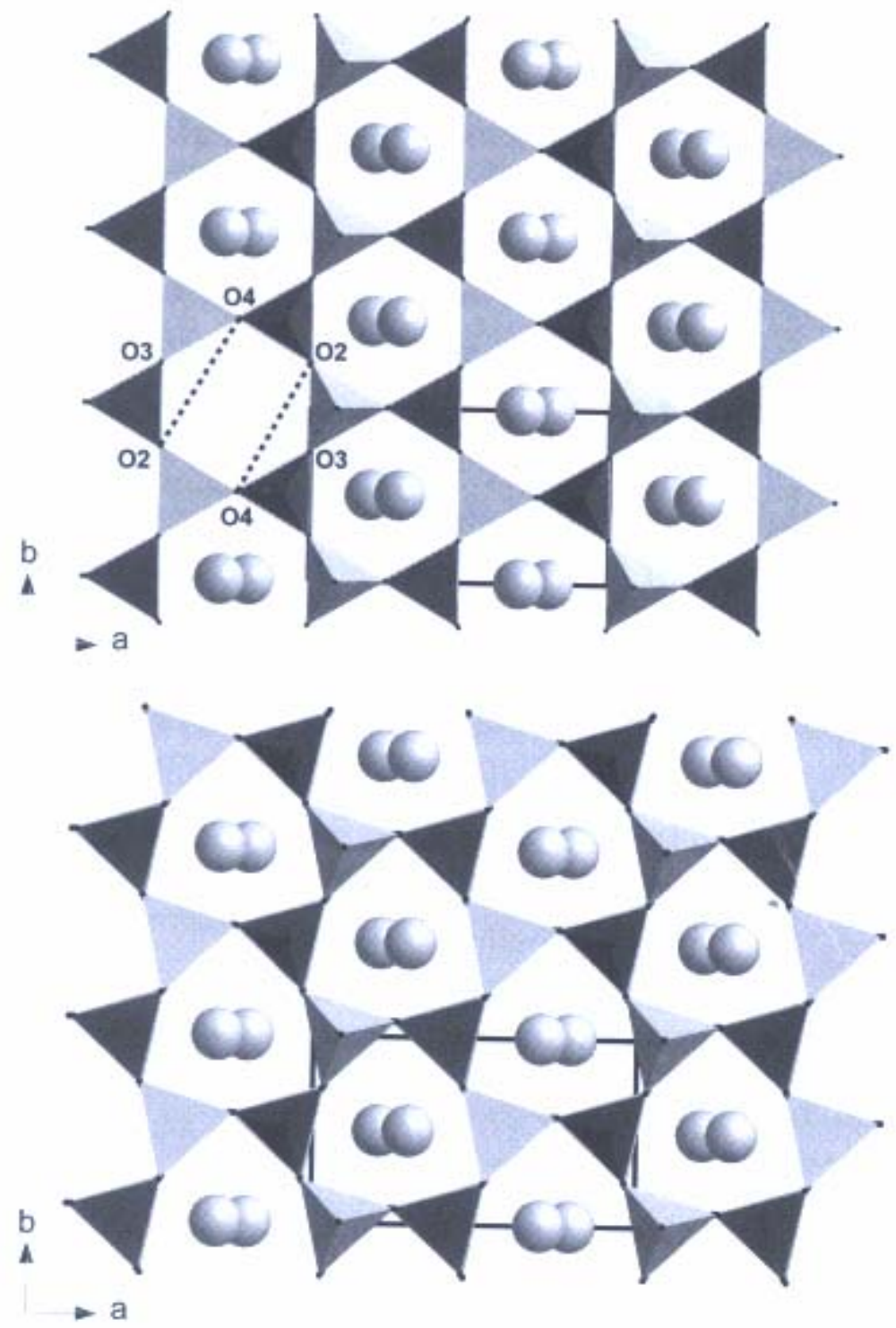

Figure 10. The crystal structure of $\mathrm{CsAlSiO}_{4}$ (above) and $\mathrm{RbAlSiO}_{4}$ (below) viewed down the crystallographic c-axis. The dark tetrahedra are occupied by $\mathrm{Si}$ and the light tetrahedra by $\mathrm{Al}$. The large spheres represent $\mathrm{Cs}$ or $\mathrm{Rb}$ ionically bonded to the numbered oxygens as shown in the top graphic (from 61). 


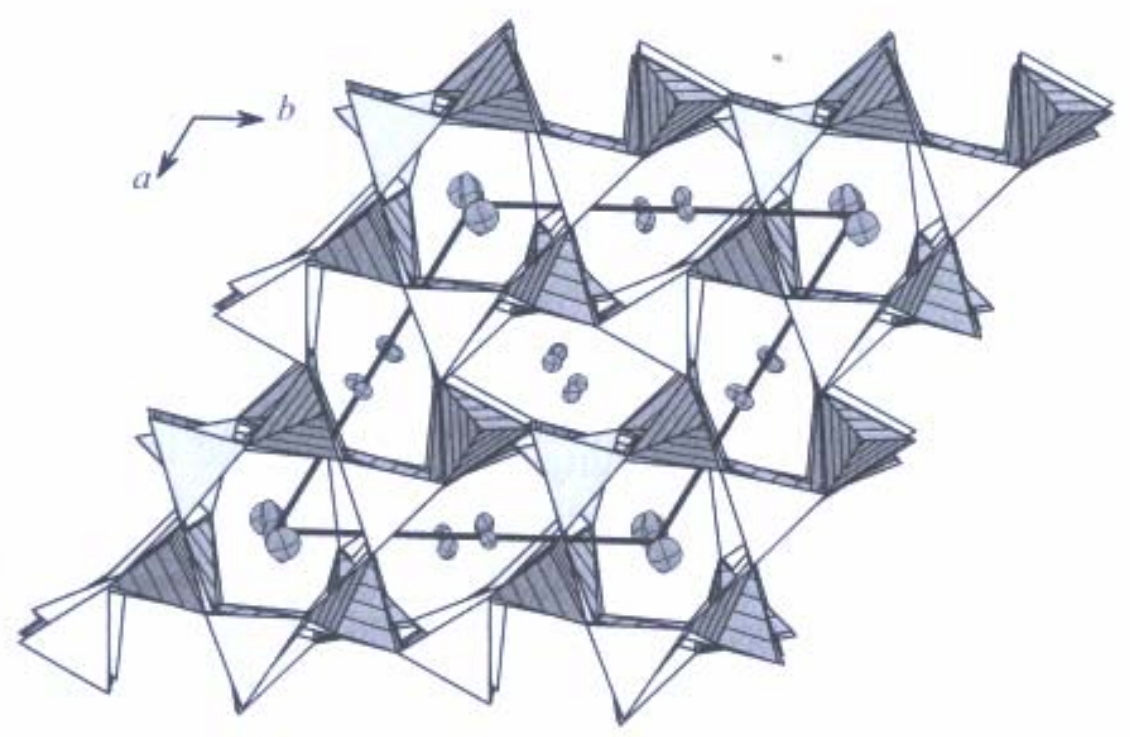

Figure 11. Crystal structure of monoclinic sodium deficient nepheline $\left(\mathrm{Na}_{7.85} \mathrm{Al}_{7.85} \mathrm{Si}_{8.15} \mathrm{O}_{32}\right.$ showing the sixfold rings made of $\left(\mathrm{SiO}_{4}\right)^{-4}$ and $\left(\mathrm{AlO}_{4}\right)^{-5}$ tetrahedra. Sodium cations are bonded ionically to oxygen atoms as in stoichiometric nepheline (from reference 62).

\subsection{Role of REDuction/OXidation (REDOX) on Bonding of Radionuclides and Contaminants}

The spinels readily accommodate many of the transition metals that are Resource Conservation and Recovery Act (RCRA) hazardous. The FBSR process is run with a reducing REDOX with a log oxygen fugacity of -20 to -21 (see Figure 14 developed for FBSR mineral product by the same scientist who developed Figure 24 in Appendix A for HLW glass speciation). Due to the reducing conditions, species such as chromium are predicted to be between $50-70 \%$ reduced to $\mathrm{Cr}^{+3}$ and thus sequestered into the spinel structure as $\mathrm{Cr}^{+3}$, since $\mathrm{Cr}^{+6}$ will not enter the spinel structure (Figure 14).

Rhenium (surrogate for $\mathrm{Tc}^{99}$ ) at the reduced oxygen fugacities is only predicted to be $2-6 \%$ reduced to the +4 state indicating that Re remains in the +7 state at these oxygen fugacities. Thus $\mathrm{Re}\left[\right.$ and $\mathrm{Tc}^{99}$ ] are in the correct oxidation state to enter the sodalite structure as $\mathrm{NaReO}_{4}$ or $\mathrm{NaTcO}_{4}$ (Figure 14). Likewise, only $1-19 \%$ of the $\mathrm{S}$ will be reduced to the +2 state, so $\mathrm{S}$ will remain oxidized in the +4 state as $\mathrm{SO}_{4}$ to enter the sodalite/nosean phase.

The fate of other radionuclides such as $\mathrm{Pu}$ and $\mathrm{U}$ are not known in the feldspathoid mineral assemblages, but it is likely that they form insoluble reduced oxide species such as $\mathrm{UO}_{2}$ and $\mathrm{PuO}_{2}$ at the reducing REDOX of the FBSR (Figure 14) in the same manner as they have in the glass bonded sodalite waste forms.[40,41] 


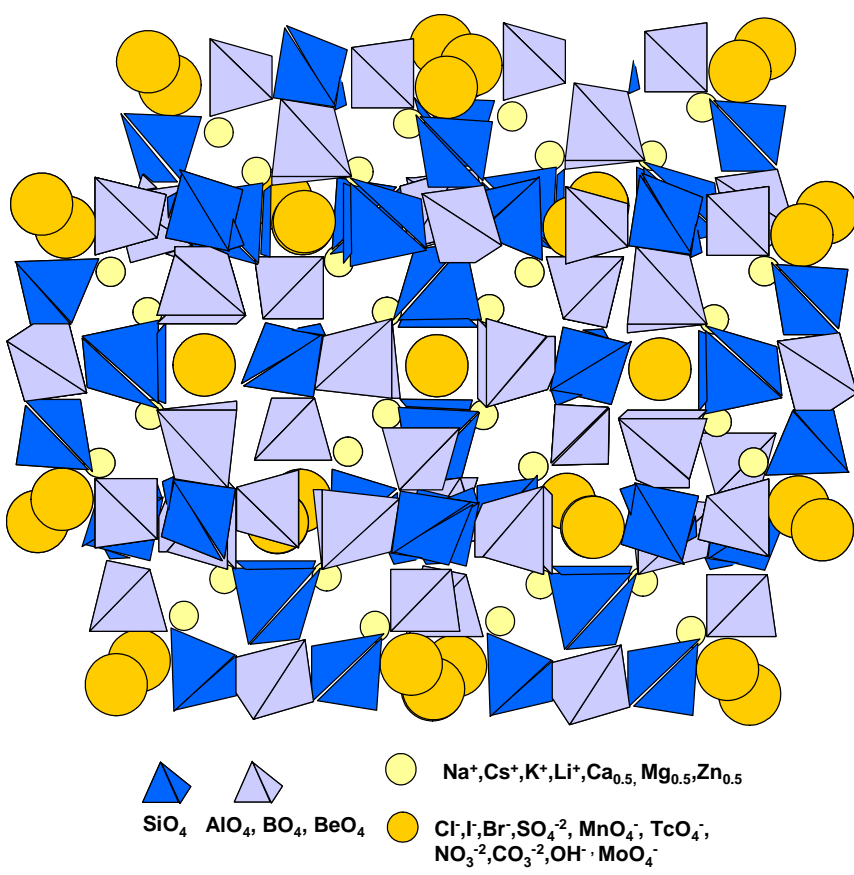

Nosean/Hauyne (multiple unit cells) - $\mathrm{S}$ is bound to 4 oxygens from one of the 6 membered framework rings of $\mathrm{SiO}_{4} / \mathrm{AlO}_{4}$ tetrahedra along the body diagonal of the cubic cell creating the $\mathrm{SO}_{4}$ molecule. In addition each $\mathrm{SO}_{4}$ is bound to two $\mathrm{Na}^{+}$in nosean or one $\mathrm{Ca}^{+2}$ in hauyne.

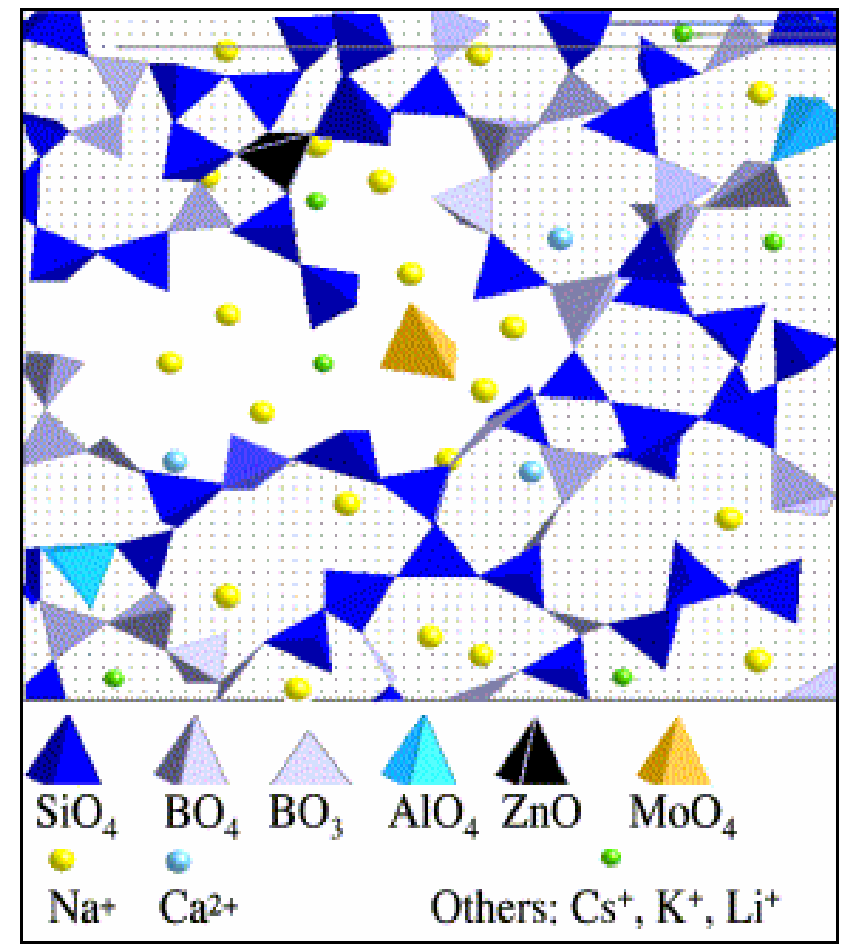

Glass - $\mathrm{SO}_{4}$ is bound similarly to $\mathrm{MoO}_{4}$ in glass. $\mathrm{S}$ is tetrahedrally bound to four oxygens and those oxygens are weakly bound to $\mathrm{Na}^{+}$and other monovalent species such as $\mathrm{Cs}^{+}$in large poorly structured cavities in borosilicate glass.

Figure 12. Comparison of the bonding of $\mathrm{SO}_{4}$ and $\mathrm{MoO}_{4}$ in glass [63] and in the sodalite family of minerals [58]. 
WSRC-STI-2008-00268

Revision 0

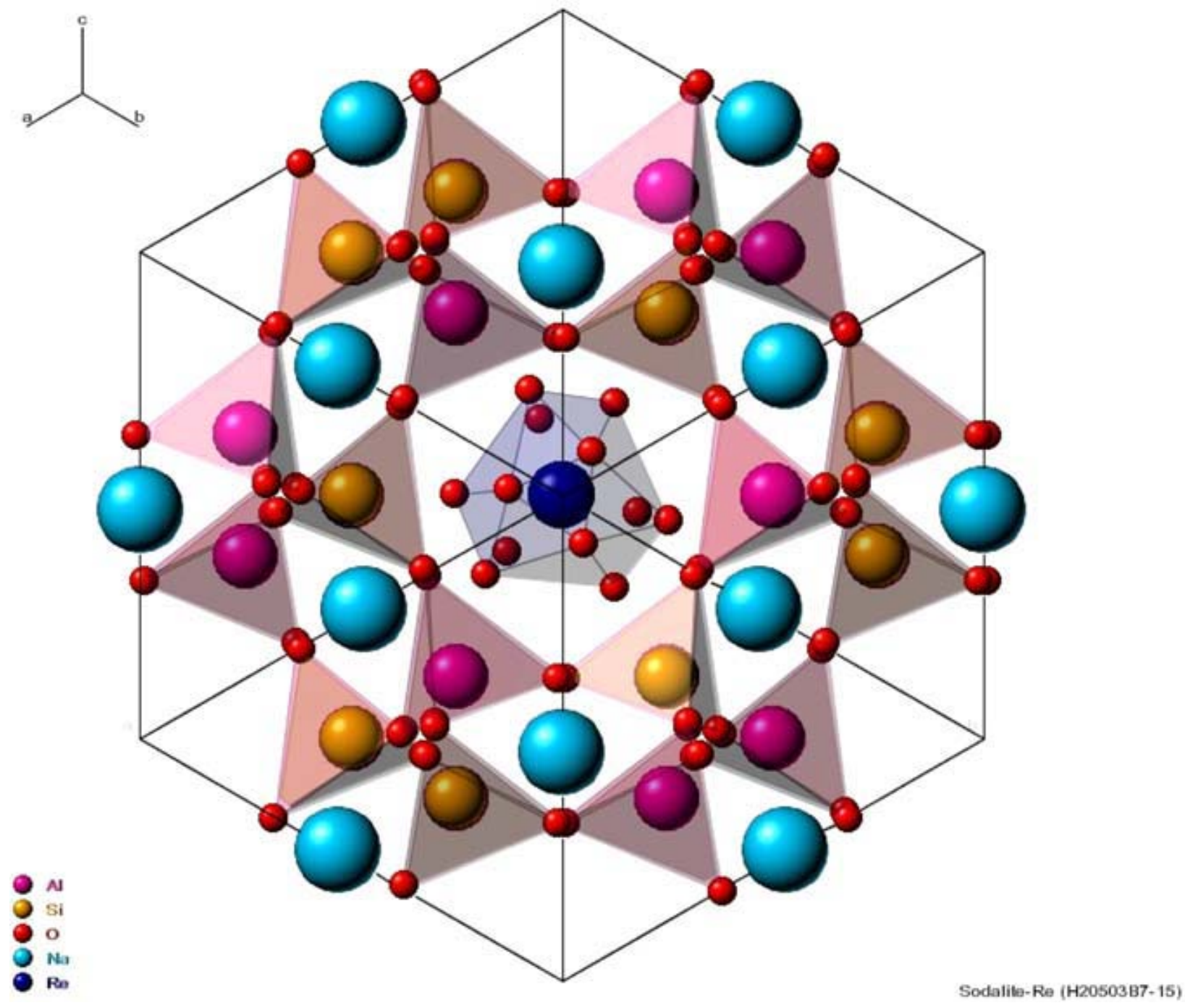

Figure 13. Bonding of Re in the perrhenate sodalite. A single unit cell is shown. [39] 


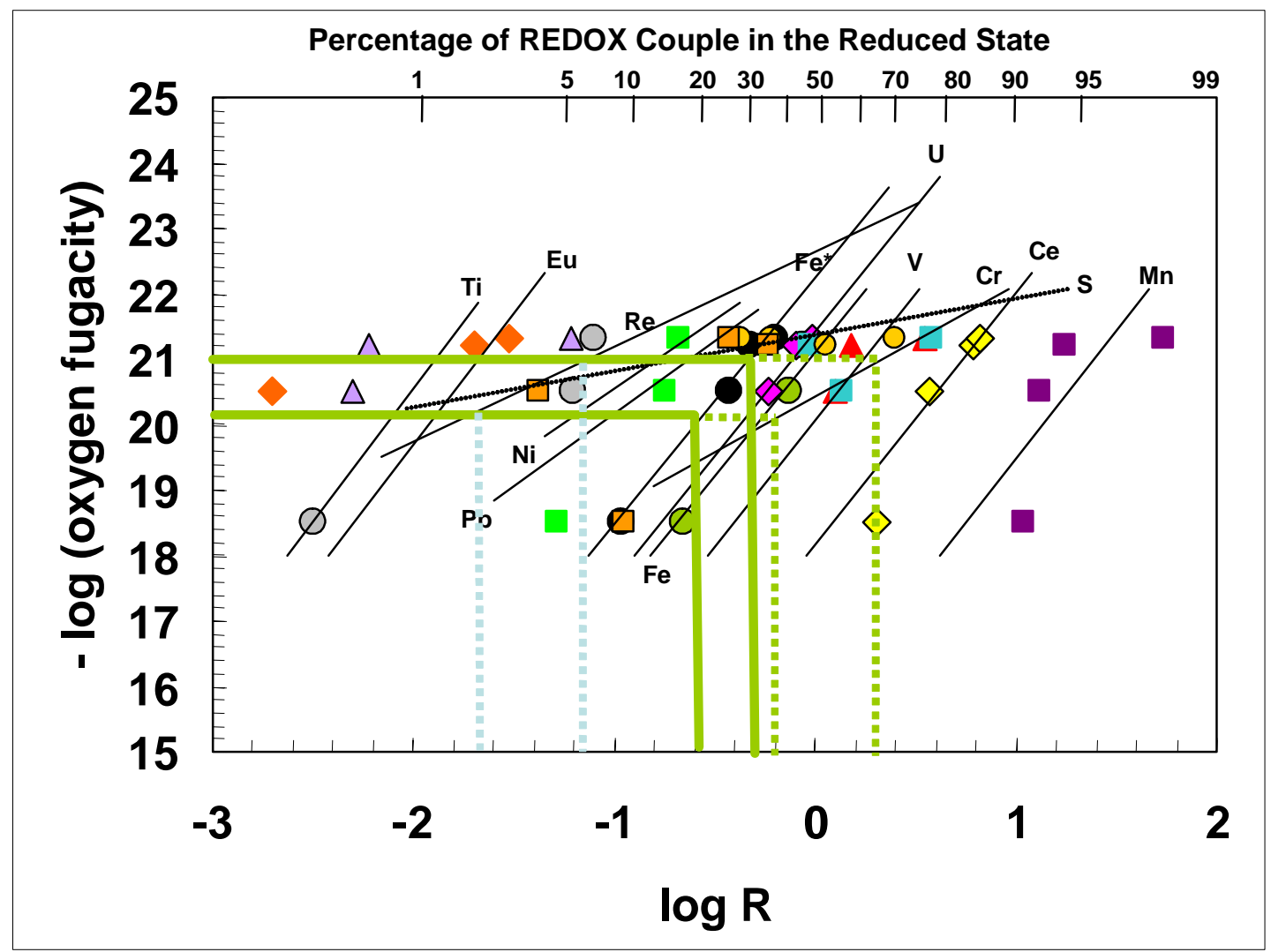

Figure 14. Electromotive Force (EMF) series developed by Schreiber for FBSR reactions. [64] $\log \mathrm{R}$ is $\log \left(\mathrm{X}^{\mathrm{red}} / \mathrm{X}^{\text {oxidized }}\right)$ so measuring the $\left(\mathrm{Fe}^{\mathrm{red}} / \mathrm{Fe}^{\text {oxidized }}\right)$ in the FBSR product fixes the log (oxygen fugacity) as indicated by the solid green lines.

Once the oxygen fugacity of the product at formation is known the oxidation state of the other multivalent elements can be determined (see dashed green lines for $\mathrm{Cr}$ REDOX and dashed blue lines for Re REDOX). It should be noted that

$$
\frac{F e^{2+}}{\sum F e}=\frac{\frac{F e^{2+}}{F e^{3+}}}{\left(1+\frac{F e^{2+}}{F e^{3+}}\right)}
$$

\subsection{Possible Contaminant Release Mechanisms from FBSR Mineral Structures}

\subsubsection{Similarity of Glass and Mineral Dissolution Mechanisms}

Dissolution of a glass or mineral waste form occurs when individual ions diffuse out of the glass/mineral structure into the leachate or condense in an alteration layer on the glass/mineral surface in contact with the leachate. In a static environment the ions in the leachate can reach saturation and reprecipitate on the glass/mineral surface. 
In Section 1.1, the concepts of congruent and incongruent dissolution were introduced. This distinction is discussed in more detail here. Congruent dissolution of a waste form is the dissolving of species in their stoichiomentric amounts. For congruent dissolution, the rate of release of a radionculide from the waste form is proportional to both the dissolution rate of the waste form and the relative abundance of the radionculide in the waste form.[65] Thus for borosilicate glass $\mathrm{Tc}^{99}$ is the radionuclide released at the fastest rate $\left(\mathrm{Cs}^{137}\right.$ is released at a somewhat slower rate). However, $\mathrm{Tc}^{99}$ is released at the same rate, congruently, as $\mathrm{Na}, \mathrm{Li}$ and $\mathrm{B}$. This enables the $\mathrm{Na}, \mathrm{Li}$, and $\mathrm{B}$ to be measured in a glass durability test and be equated to the "maximum radionuclide release." For this reason, durability tests such as ASTM C1285 procedure (the Product Consistency Test; 66) specifies that for vitreous waste forms containing $\mathrm{Na}, \mathrm{Li}$, and/or $\mathrm{B}$ that these cations be monitored to determine the "maximum radionuclide release" from the homogeneous glass (see an extended discussion in Appendix A and references 67, 68, 69, 70, 71, 72, 73, 74, 75).

Incongruent dissolution means that some of the dissolving species are released preferentially to others. Glass-ceramics and mineral/ceramic waste forms normally leach incongruently (see Section 1.1), e.g. the ratio of the individual ions in solution do not occur in the same ratio as in the parent solid [65] because there is a less soluble reaction product that accumulates and can precipitate either on the dissolving surface to form a surface layer or in solution to form a colloidal species. Hence $\mathrm{Na}$ may be released preferentially to $\mathrm{Tc}^{99}$ and not be a good indicator of the "maximum radionuclide release." This is especially true when the source of the Na may be from two or three different sodium rich phases, e.g. sodalite, nepheline, nosean, while the $\mathrm{Tc}^{99}$ may only be sequestered in one of those three phases. Incongruent dissolution is often diffusion-controlled and can be either surface reactionlimited under conditions of near saturation or mass transport-controlled. Preferential phase dissolution, ion-exchange reactions, grain-boundary dissolution, and dissolution-reaction product formation (surface crystallization and recrystallization) are among the more likely mechanism of incongruent dissolution, which will prevail, in a polyphase mineral/ceramic waste form, a glass ceramic, or a phase separated glass [5]. For this reason, durability tests such as ASTM C1285 procedure (the Product Consistency Test; 66) and the various ANL research reports $[40,41]$ specify that for glass bonded sodalites that different cations be monitored for each phase present to determine the "maximum radionuclide release" from each phase, e.g. unique elements and/or radionuclides are monitored from the glassy phase, the halide phases, and the sodalite phase:

- $\mathrm{Si}, \mathrm{Al}, \mathrm{Na}, \mathrm{Li}$ (sodalite and glass)

- B (glass)

- $\mathrm{Cl}$ (sodalite and halite)

There are four primary mechanisms that together control the overall durability of a glass or mineral waste form. These four mechanisms include ion exchange, matrix dissolution, accelerated matrix dissolution, and surface layer (possibly of a protective or passivating nature) formation as described below $[76,77,78]$ :

- Ion exchange is the exchange of cations in the glass/mineral for $\mathrm{H}_{2} \mathrm{O}$ or $\mathrm{H}^{+}$in solution. 
- Matrix dissolution is the release of silica or alumina, $\left(\mathrm{SiO}_{4}\right)^{-4}$ or $\left.\mathrm{AlO}_{4}\right)^{-5}$, from the waste form structural (tetrahedral) units by $\mathrm{OH}^{-}$attack where the $\mathrm{OH}^{-}$are released by the ion exchange reactions, e.g. $+\mathrm{Si}-\mathrm{OM}+\mathrm{H}_{2} \mathrm{O} \rightarrow+\mathrm{Si}-\mathrm{OH}+\mathrm{M}^{+}$ $+\mathrm{OH}^{-}$and $\mathrm{M}^{+}$is a monovalent metal cation and $\mathrm{Si}-\mathrm{OH}$ is a silanol bond in the altered gel layer on the glass/mineral surface.

- Accelerated matrix dissolution is continued attack of the glass/mineral matrix from the $\mathrm{OH}^{-}$being released by both ion exhange reactions and matrix dissolution reactions.

- Surface layer formation is due to saturation of certain species in the solution that can cause precipitated (amorphous) or crystalline species to form on or condense in the glass/mineral surface. Species such as clays can precipitate from solution on the gel layer and/or from in-situ alteration in the gel layer.

Recent studies have demonstrated that the rate-limiting step in silica-water reactions (glass or mineral) is breakage of the structural $\mathrm{Si}-\mathrm{O}$ bonds. [79,80,81] Oelkers [80] has shown that the mechanisms by which single phase minerals and glasses leach are similar. Thus the modeling of the chemical durability of glass, e.g. glass-solution interactions, has paralleled the modeling of mineral-solution durability in that the kinetic treatments have systematized the effects of $\mathrm{pH}$, temperature, saturation state, ionic strength of the leachant, and inhibition, on the overall dissolution rate by developing models that treat each effect individually. [82] The kinetic effects of saturation state as a function of $\mathrm{pH}$, temperature, and ionic strength have primarily been handled by the application of Transition State Theory (TST) and the free energy dependence of basic irreversible dissolution reactions [83,84,85].

The TST and irreversible dissolution reactions originally developed by geochemists such as Oelkers [80,81], Lasaga [82,85] and Helgeson $[83,84]$ for mineral dissolution (albite/ $\mathrm{NaAlSi}_{3} \mathrm{O}_{8}$ and nepheline $/ \mathrm{NaAlSiO}_{4}$ ) are those currently being used to predict longterm HLW waste glass dissolution in the Yucca Mountain Total System Performance

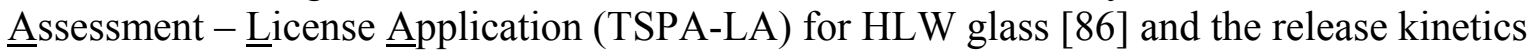
for ILAW (Immobilized LAW) performance assessment at Hanford.[87]

In the TST treatment of the chemical durability of minerals and glasses, the rate-limiting step is considered to be the destruction of the slowest breaking metal-oxygen bonds, e.g., those that are essential for maintaining the mineral or glass structure, i.e. $\left(\mathrm{SiO}_{4}\right)^{-4},\left(\mathrm{AlO}_{4}\right)^{-5}$ etc. [80,81] Determination of which dissolution pathway is fastest, and thus rate controlling, requires the identification of any and all processes that could accelerate the destruction of the slowest breaking metal-oxygen bonds. For dissolution of feldspars (alkali aluminosilicates), the rate limiting step was found to be partial liberation of a metal by the removal of adjacent metals through previously equilibrated exchange reactions, e.g. an $\mathrm{Al}^{3+}$ is exchanged for $3 \mathrm{H}^{+}$ ( 3 protons) on the surface of the mineral or glass. This leads to the formation of three partially liberated neighboring $\mathrm{Si}$ atoms. [80,81] The three partially liberated $\mathrm{Si}$ atoms that form due to the leaching of an $\mathrm{Al}^{3+}$ are then partially detached forming the slow-exchanging metal oxide precursor complex that is rate controlling (Figure 15). For minerals that do not contain $\mathrm{Al}^{3+}$, other metal/proton exchange reactions partially liberate the silica tetrahedral chains. For example, in $\mathrm{MgSiO}_{3}$ (enstatite) and $\mathrm{Mg}_{2} \mathrm{SiO}_{4}$ (forsterite) minerals, the $\mathrm{Mg}$ /proton 
exchange is responsible for the partial liberation of the silica; for $\mathrm{CaSiO}_{3}$ (wollastonite), it is the $\mathrm{Ca}$ /proton exchange that is responsible for the partial liberation of the silica. [80]

The Al/proton exchange has also been shown to be the rate controlling step in basalt glass dissolution [88] regardless of whether dissolution is performed in acidic or basic solutions. The basalt glass dissolution is described as a rapid removal of univalent and divalent cations from the near surface, an ion exchange like reaction (Figure $15 \mathrm{~A}$ ), followed by the $\mathrm{Al}^{3+}$ and $3 \mathrm{H}^{+}$exchange (Figure 15B). The breaking of the Al-O bonds does not destroy the glass framework, but it partially liberates the silica tetrahedral chains as in the crystalline feldspar dissolution mechanism [80]. It is the detachment of this partially liberated silica (Figure $15 \mathrm{C}$ ) that is the rate determining step, e.g., partially detached silica dissolves more readily than attached tetrahedral silica. The basalt glass dissolution is therefore proportional to the concentration of partially detached framework tetrahedral Si near the surface, which is linked through the law of mass action to the concentration of $\mathrm{Al}$ in the glass or via the $\mathrm{Al} /$ proton exchange reaction and to the aqueous aluminum activity in the leachate. The rate determining step should not be confused with the "maximum radionuclide release", which can be controlled by the rapid ion exchange reactions. Such is the case for $\mathrm{Li}$ and $\mathrm{Na}$ in borosilicate glass.

The $\mathrm{Al} /$ proton mechanism for basalt glass [88] and crystalline albite $\left(\mathrm{NaAlSi}_{3} \mathrm{O}_{8}\right)$ dissolution $[80,81]$ was show to be the mechanism by which the French HLW glass known as R7T7 and a pure albite glass dissolve.[89] The French study demonstrated that the TST rate equations only predict the glass alteration rate when a gel layer is missing or non-protective. These researchers hypothesized that the dissolution rate decreases by several orders of magnitude after an initial accelerated rate as the dissolution reaction progresses because a rate-limiting mechanism hampers mass transfer between the unreacted glass and the solution. In the French experiments, the $\mathrm{SiO}_{2}$ activity in solution was kept constant and only the $\mathrm{Al}(\mathrm{OH})_{4}^{-}$ activity in solution was varied. Small changes in the activity of the $\mathrm{Al}(\mathrm{OH})_{4}^{-}$aqueous species had a major impact on the glass dissolution kinetics (this will be shown to be applicable to the dissolution of the FBSR mineral phases in the section on durability). Additional studies confirmed that the glass dissolution was controlled by both glass composition and the chemistry of the fluid contacting the glass.[90]

Alkali and alkaline earth elements from the FBSR mineral phases are thus expected to leach by ion exchange from the larger $(8,10,12$ coordinated oxygen sites) less well defined coordination polyhedra in mineral structures with LRO, while elements that form the aluminosilicate framework tetrahedra, e.g. Al, $\mathrm{Si}, \mathrm{Be}$, rare earths, are expected to leach by matrix dissolution, e.g. Al/proton and $\mathrm{Si}$ /proton dissolution. The exception to this would likely be the species in the cage structures of the sodalite phases, e.g. S, Cl, I, Re (simulant for Tc). Since the cage structures bond these species more rigidly (Figure 12a) than the larger $(8,10,12$ coordinated oxygen sites) less well defined coordination polyhedra in the mineral structures, it would be expected that the leach rate of these species from the FBSR mineral products would be lower than the leach rate of these species from glass, e.g. compare the coordination sites in which $\mathrm{SO}_{4}$ and $\mathrm{MoO}_{4}$ are bound in a mineral structure (Figure 12a) to those in a glass structure (Figure 12b) $[67,68,69,70,71,72,73,74,75]$ 


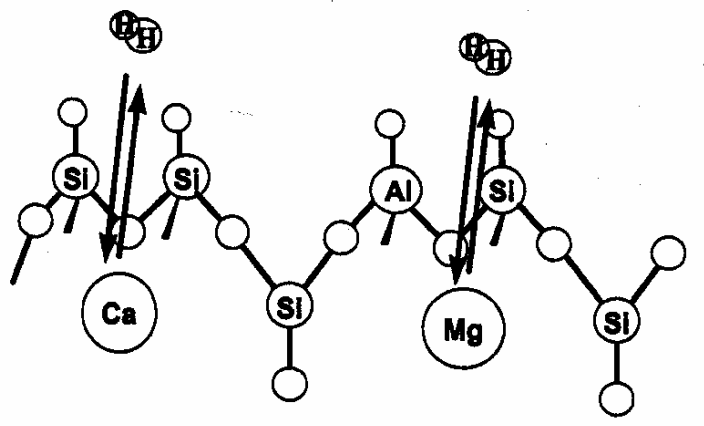

$\mathbf{A}$

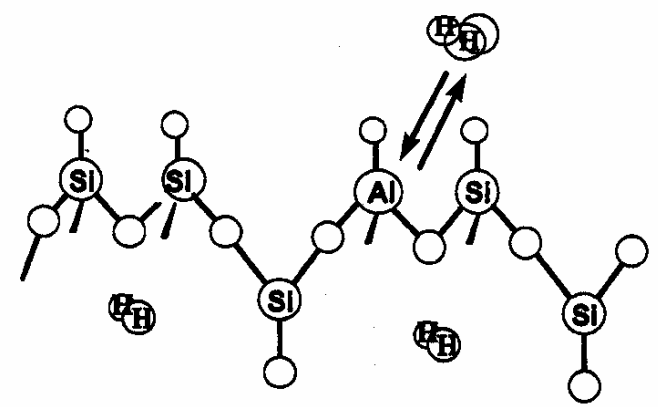

B

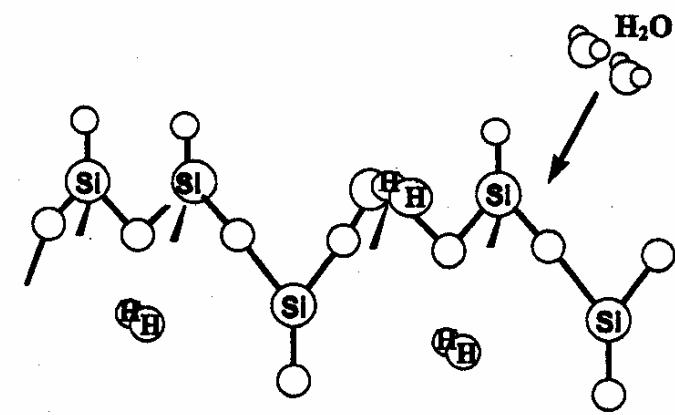

$\mathbf{C}$

Figure 15. Schematic illustration of the basalt glass dissolution mechanism consisting of (A) the removal of univarient and divarient cations from the glass surface via proton exchange, (B) the partial removal of $\mathrm{Al}$ from the glass framework via proton exchange, and $(\mathrm{C})$ the final liberation of the already partially detached framework tetrahedral Si (from Reference 88).

No matter what waste form is being evaluated, a variety of durability tests must be performed to determine whether congruent or incongruent leaching is occurring. Testing must also be performed to determine if matrix dissolution is necessary before a radionuclide is released or whether the radionuclides are being released by ion exchange before matrix dissolution occurs. If the glass or mineral waste form is single phase this determination is considerably easier than if the glass or mineral waste form is multiphase. 
The approach taken for establishing testing protocols for waste forms, both current and future [91], is based on the logic in ASTM Standard C1174 entitled "Prediction of the Long-Term Behavior of Materials, Including Waste Forms, Used in Engineered Barrier Systems (EBS) for Geological Disposal of High-Level Radioactive Waste." [92]. This standard was developed to provide a template to integrate waste form durability testing and modeling. It includes interactive modules that relate stress the importance of defining the problem, characterizing the disposal environment, maintaining interfaces and iterations between testing and modeling, using analog materials and systems, validating a model to the determined mechanism, and confirming the appropriateness of the model for the disposal system. Although ASTM C1174 was developed to addresses testing regarding Performance Assessment (PA) modeling, the approach is equally applicable to testing intended for establishing process control and demonstrating waste form acceptance.

An important aspect of the ASTM C1174 approach is identifying what information is provided by a particular test method and how that information should be applied. It also recognizes that a given test method can be used to address more than one issue. For most waste forms, it is expected that several test methods (see Appendix $\mathrm{C}$ ) will be needed to understand the degradation mechanism(s) well enough to develop a performance model. Many of the tests and analyses address multiple information needs. For example, many tests provide insight into the waste form matrix degradation mechanism and the radionuclide release mode that may be by ion-exchange as described below:

- Identify the radionuclide release mechanism - tests must determine if the radionuclide is released congruently with the matrix or incongruently. In most cases, these tests will serve to confirm the release mode based on an understanding of the matrix material and how the individual radionuclides are incorporated. Testing must determine if the release of various radionuclides is by diffusion (ion exchange), congruent dissolution of the matrix, or dissolution of the matrix to expose the phase containing the radionuclide, which then may dissolve or be released as a colloid.[91]

- Determine the matrix degradation mechanism - It is anticipated that radionuclides will be released by degradation of the waste form matrix, either physically or chemically. Dissolution of the matrix may be required before a radionuclide can be released, or it may simply need to be physically or chemically altered. Removal or reaction of a particular component in the matrix may be required to provide a pathway for release of the radionuclide. For some of the multi-phase waste forms, dissolution of an encapsulating material may be required before water can contact and react with the phase bearing the radionuclide. The durability of both the matrix and the radionuclide-bearing phase will then affect its release, and these may occur by different mechanisms. [91] 


\subsection{Current Knowledge About FBSR Mineral Dissolution and Contaminant Release}

For most waste forms a combination of the ASTM C1285 (Product Consistency Test, PCT) and the ASTM 1662 (SPFT test) are used to evaluate new waste forms. This can be followed by testing using any of the other durability tests discussed in Appendix $\mathrm{C}$ to enhance the mechanistic understanding of the durability response. Care should be taken in the measurement of surface area for both tests and in the choice of leachant buffers for the SPFT as described in Appendix D.

The PCT relates waste form processing to waste form performance. It is a short-term test method yielding a response that is sensitive to both the effects of processing variables on the waste form and its chemical durability. The attributes or constituents that should be tracked will depend on the waste form and its degradation mechanism. The phase composition of multi-phase waste forms may be important to performance, or only the concentration of a key radionuclide or hazardous species [91]. In the case of homogeneous borosilicate HLW glasses being made with tank wastes, acceptable performance is defined as an acceptably low dissolution rate, which is controlled by maintaining the glass composition within an acceptable range. The approach can be represented in terms of linking several relationships:

process control $\leftrightarrow$ composition control $\leftrightarrow$ dissolution rate control $\leftrightarrow$ performance control $\leftrightarrow$ acceptable performance

This linkage is appropriate for waste glasses because the radionuclides are incorporated within the glass structure and are released congruently as the glass dissolves. In general, for any waste form it must be established that control of performance in a laboratory test (i.e., the product consistency test) predicts acceptable control of performance in a disposal system based on performance tests and modeling.

The role of FBSR durability testing is to establish these same types of linkages for the FBSR mineral waste form products. Reference 93 has established the link between "process control $\leftrightarrow$ composition control”. The PCT [94,95,96,97], SPFT [97,98,99,100,101] and PUF [98] tests have been performed on multiple FBSR products and the results of the SPFT and PUF tests have been used in the Hanford PA assessment [98,99]. The FBSR mineral dissolution has been compared to glass dissolution (similar mechanisms) to establish the remainder of these linkages, e.g. "composition control $\leftrightarrow$ dissolution rate control $\leftrightarrow$ performance control $\leftrightarrow$ accepted performance”.

The FBSR mineral waste form is multiphase and granular in nature. While $\mathrm{Na}, \mathrm{Al}$, and $\mathrm{Si}$ are components of the various phases, determination of the rate limiting dissolution step is the key to understanding the durability mechanism.[91] However, only certain phases such as sodalite/nosean are the host mineral phases for Re (Tc), Cl, I, etc. So, whereas glass leaches congruently, e.g. soluble species such as $\mathrm{Na}, \mathrm{B}$, and $\mathrm{Tc}^{99}$ are all dissolved at the same rate, the FBSR mineral waste form may leach incongruently and the rate of $\mathrm{Tc}^{99}$ release will likely not be equivalent to the rate of the Na release unless both are released by the same 
mechanism, e.g. ion exchange. For example, if $\mathrm{Tc}^{99}$ is released only after the matrix degrades, then the $\mathrm{Tc}^{99}$ release will be equivalent to the rate at which $\mathrm{Si}$ is released.

Since the FBSR product was a new waste form and researchers were unsure of whether the radionuclides were released congruently or incongruently, the leaching of the radionuclides of interest or their surrogates (Re in the case of Tc-99, I-127 for I-129, and Cs-133 for Cs137) were monitored separately from the durability of the major cations, $\mathrm{Na}, \mathrm{Al}$, and $\mathrm{Si}$ during both PCT analysis and SPFT durability testing.[94,95,96,97,98,99,100,101] In the FBSR waste form the radionuclide releases $\mathrm{Re}$ (simulant for $\mathrm{Tc}^{99}$ ) and $\mathrm{Cs}$ are retarded preferentially to the Na release [94,95,96; Table IV]. This finding is noteworthy because the Hanford specification for $\mathrm{Na}$ release for glass waste forms is an indicator for the congruent release of $\mathrm{Tc}^{99}$, since $\mathrm{Na}$ and $\mathrm{B}$ and $\mathrm{Tc}^{99}$ are all released at similar rates (congruently). However, Table IV clearly indicates that the Na release from multiple Na-containing phases in the FBSR is greater than the release of Cs or Re (surrogate for $\mathrm{Tc}^{99}$ ), as the Re is likely contained in only one sodium bearing phase, sodalite and/or nosean, while $\mathrm{Na}$ is being released from multiple phases (including some that may not be contaminant hosts). So for FBSR products the Re and/or Cs release should be compared to the Na or B release from glass as done by Jantzen and others [94,95,96,97].

Table IV. PCT Performance of FBSR Sample SCT02-098-FM and the Durability Response of Known Glass Standards Using Geometric Surface Area [94]

\begin{tabular}{|c|c|c|c|c|c|}
\hline Sample & $\mathrm{pH}$ & $\begin{array}{c}\mathrm{NL}_{(\mathrm{Na})} \\
\mathrm{g} / \mathrm{m}^{2}\end{array}$ & $\begin{array}{c}\mathrm{NL}_{(\mathrm{Cs})} \\
\mathrm{g} / \mathrm{m}^{2}\end{array}$ & $\begin{array}{c}\mathrm{NL}_{(\mathrm{Re})} \\
\mathrm{g} / \mathrm{m}^{2}\end{array}$ & $\begin{array}{c}\mathrm{NL}_{(\mathrm{Si})} \\
\mathrm{g} / \mathrm{m}^{2}\end{array}$ \\
\hline AN-107 FBSR & 11.95 & 1.74 & 0.16 & $\begin{array}{c}0.29 \\
(0.22)^{*}\end{array}$ & 0.35 \\
\hline AN-107 FBSR $*$ & 11.98 & $f$ & $f$ & 0.22 & 0.48 \\
\hline LAW REF & 10.90 & 0.54 & --- & --- & 0.16 \\
\hline AN-102 RAD GLASS & 10.60 & 0.35 & --- & --- & 0.12 \\
\hline
\end{tabular}

$*=$ rerun in Teflon vessels, $f=$ analysis indicated that vessel blanks were contaminated

During PCT testing [94,96,97] of FBSR product made from LAW Envelope A, from LAW Envelope C (AN-107), and INL SBW, the data in Table IV were reported in $\mathrm{g} / \mathrm{m}^{2}$ using the BET surface area to be consistent with the BET surface area being used during SPFT testing by McGrail $[98,99]$ and others $[100,101,156,157,158]$. The PCT final leachate $\mathrm{pH}$ values were an inverse function of the sample surface area $\mathrm{SA}_{\mathrm{BET}}\left(\mathrm{m}^{2} / \mathrm{g}\right)$ (Figure 16), e.g. the $\mathrm{pH}$ is lower for samples with a larger $\mathrm{SA}_{\mathrm{BET}}\left(\mathrm{m}^{2} / \mathrm{g}\right)$. In addition, the $\mathrm{pH}$ appears to be dependent on the Al:Si ratio of the mineral species formed during FBSR. The non-stoichiometry of the $\mathrm{Al}$ :Si ratio helps set up an aluminum buffering mechanism that controls the leachate $\mathrm{pH}$ during static testing like the PCT, i.e. the release of alkali and hydroxide occurs during the early stages of dissolution of mineral and glass waste forms by ion exchange. The ionexchange reaction shown in Equation 1 liberates hydroxide which drives the static test 
leachates basic as a function of reaction time. Stoichiometric nepheline (where $x=1, y=1$ and $\mathrm{z}=1$ ) liberates one mole of $\mathrm{OH}^{-}$for every mole of nepheline. In non-stoichiometric nepheline (where $\mathrm{x} \neq 1, \mathrm{y} \neq 1$ and $\mathrm{z} \neq 1$ ) between 0.9 to 1.53 moles of $\mathrm{OH}^{-}$are released (see reference 96 for details). As the PCT test continues the solution changes from a pH of 5.5 to $>10$ and passes through different aqueous stability fields, e.g. $\mathrm{HSiO}_{3}^{-}, \mathrm{SiO}_{3}^{=}$and $\mathrm{Al}(\mathrm{OH})_{4}^{-}$.

Equation 1

$$
\mathrm{Na}_{x} \mathrm{Al}_{y} \mathrm{Si}_{z} \mathrm{O}_{4}+(0.5 x+1.5 y+z) \mathrm{H}_{2} \mathrm{O} \stackrel{90^{\circ} \mathrm{C}}{\longrightarrow} x \mathrm{Na}^{+}+\mathrm{zH}_{2} \mathrm{SiO}_{3}+y \mathrm{Al}(\mathrm{OH})_{3}+x(\mathrm{OH})^{-}
$$

As the $\mathrm{pH}$ increases during PCT testing, Equation 2 becomes dominant for the sodium aluminosilicate minerals in the FBSR product. Per Equation 2 non-stoichiometric nephelines and sodalites complex different amounts of hydroxide as $\mathrm{Al}(\mathrm{OH})_{4}^{-}$thus lowering the solution $\mathrm{pH}$ by aluminate buffering:

\section{Equation 2}

$$
\mathrm{Na}_{x} \mathrm{Al}_{y} \mathrm{Si}_{z} \mathrm{O}_{4}+(0.5 x+1.5 y) \mathrm{H}_{2} \mathrm{O}+(y+\mathrm{z}-x) \mathrm{OH}^{-} \stackrel{90^{\circ} \mathrm{C}}{\longrightarrow} x \mathrm{Na}^{+}+\mathrm{zHSiO}_{3}^{-}+y \mathrm{Al}(\mathrm{OH})_{4}^{-}
$$

This can be confirmed graphically (

) by showing the strong dependence of the PCT normalized releases for the alkalis ( $\mathrm{Na}$ and $\mathrm{Cs}$ ) versus the normalized releases for alumina.

When the $\mathrm{pH}$ reaches 11.7 , the stable aqueous silica species is $\mathrm{SiO}_{3}^{=}$. At this point Equation 3 becomes dominant at $90^{\circ} \mathrm{C}$ and the release of $\mathrm{H}^{+}$to the solution provides silicate buffering: Equation 3

$$
\mathrm{Na}_{x} \mathrm{Al}_{y} \mathrm{Si}_{z} \mathrm{O}_{4}+(0.5 x+1.5 y) \mathrm{H}_{2} \mathrm{O}+(y+\mathrm{z}-x) \mathrm{OH}^{-} \stackrel{90^{\circ} \mathrm{C}}{\longrightarrow} x \mathrm{Na}^{+}+\mathrm{zSiO}_{3}^{-}+y \mathrm{Al}(\mathrm{OH})_{4}^{-}+z \mathrm{H}^{+}
$$


WSRC-STI-2008-00268

Revision 0

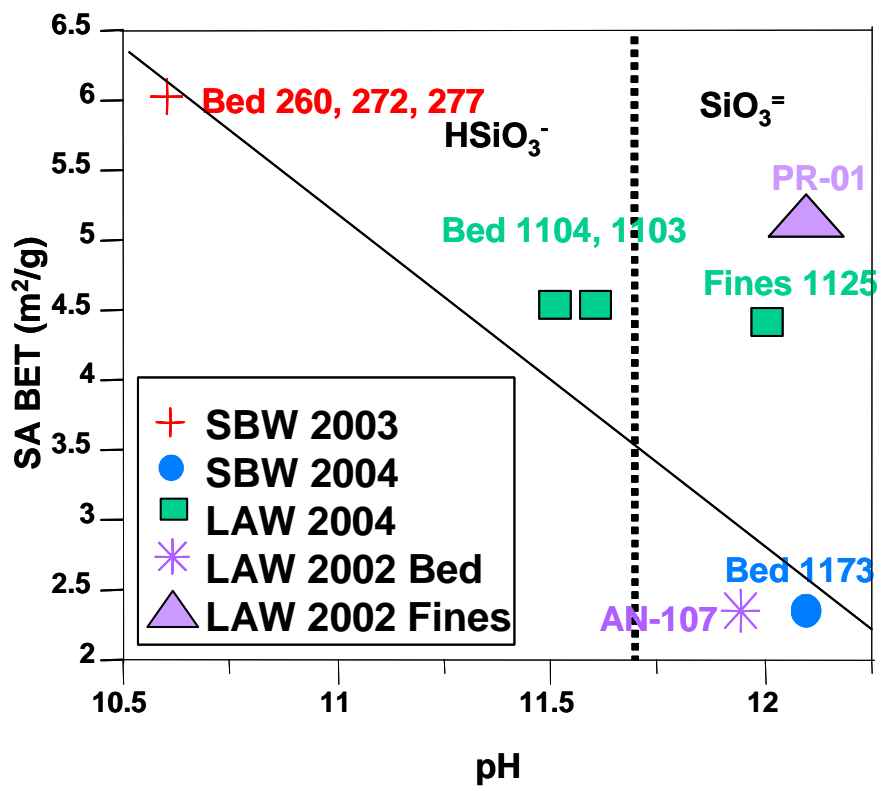

Figure 16. Relationship between surface area $\left(\mathrm{SA}_{\mathrm{BET}}\right)$ and PCT final leachate $\mathrm{pH}$.
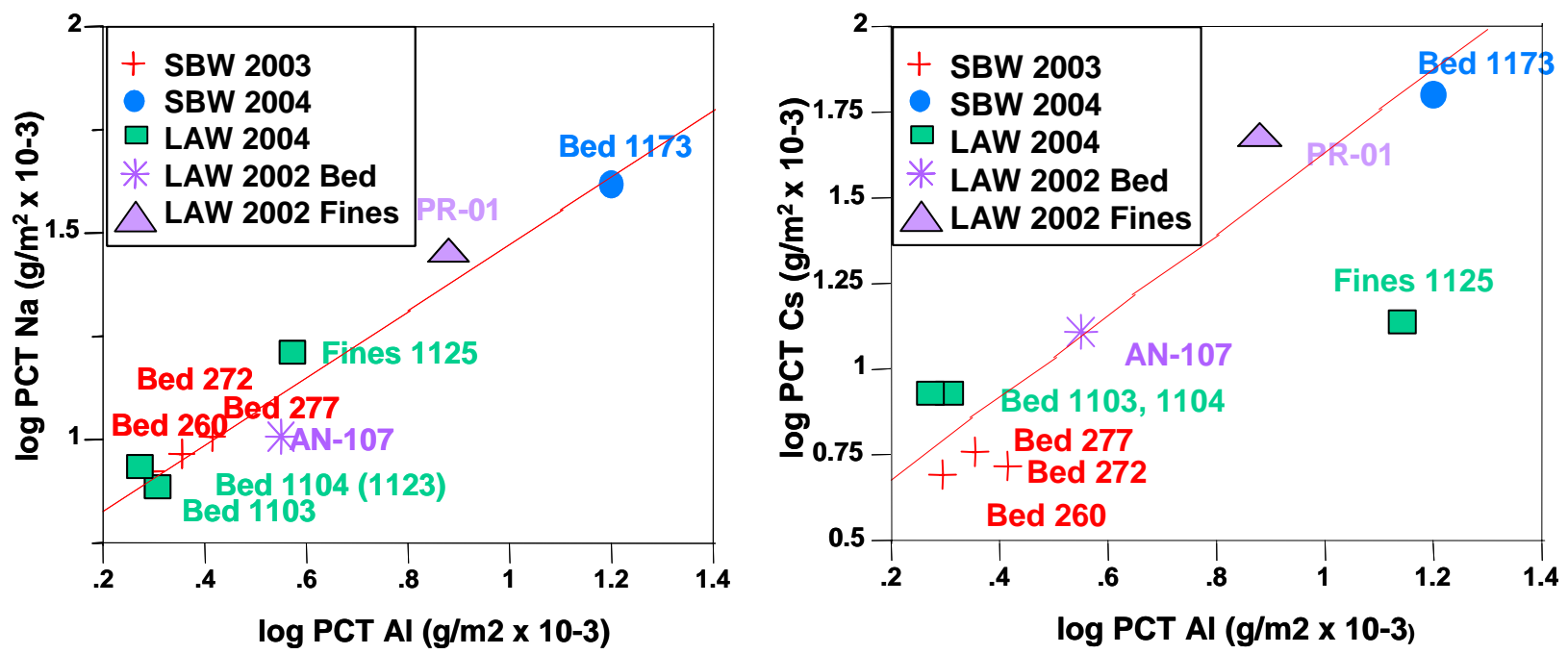

Figure 17. Linearity of alkali and alumina released to solution. Alkali dissolution generates free $\mathrm{OH}^{-}$in solution while alumina in solution complexes $\mathrm{OH}^{-}$from solution. 
Therefore, the leaching of the FBSR aluminosilicate minerals are highly governed by aluminosilicate buffering. Note that the LAW-A fines leachate $\mathrm{pH}$ is $\sim 12$ (FBSR product 1125). This $\mathrm{pH}$ is higher than the bed LAW bed products (1103 and 1104) because they are less well buffered. This is confirmed by the fact that the fines contain less (only a "trace") of the Si-rich nepheline instead of it being a major phase as it is in the bed samples. For comparison the leaching of the LAW-C AN-107 sample is governed solely by the aluminosilicate buffering of stoichiometric and Na-rich nepheline. The LAW-C fines (PR$01)$ are governed by the stoichiometric nepheline and carnegieite aluminosilicate reactions (Equation 1, Equation 2 Equation 3).

Figure 18 shows that the Re, S, and Si released to the PCT leachate are a strong function of the leachate final $\mathrm{pH}$ as controlled by the aluminosilicate buffering reactions discussed above. The poor correlation of $\mathrm{Re}$ with $\mathrm{pH}$ is likely due to the difficulties in measuring this element which was only present at concentrations of 0.0044 to $0.028 \mathrm{wt} \% \mathrm{ReO}_{2}$ in the final FBSR bed product and at lower concentrations in the leachate. Because the Re, S, and Si release are each strongly correlated to $\mathrm{pH}$, the releases are highly correlated to each other.

While the PCT is a simple screening test that can provide mechanistic data such as the Al buffering described above as well as product consistency, the SPFT requires a variety of flow rates, a variety of temperatures, and a variety of $\mathrm{pH}$ buffer solutions to test the product. This produces a multitude of leachates for analyses which are used to calculate a steady state dissolution rate, reaction order $(\eta)$, and activation energies of dissolution which are parameters needed for Performance Assessments (PA) to be completed on the FBSR mineral waste form (see Equation 9). 
WSRC-STI-2008-00268

Revision 0
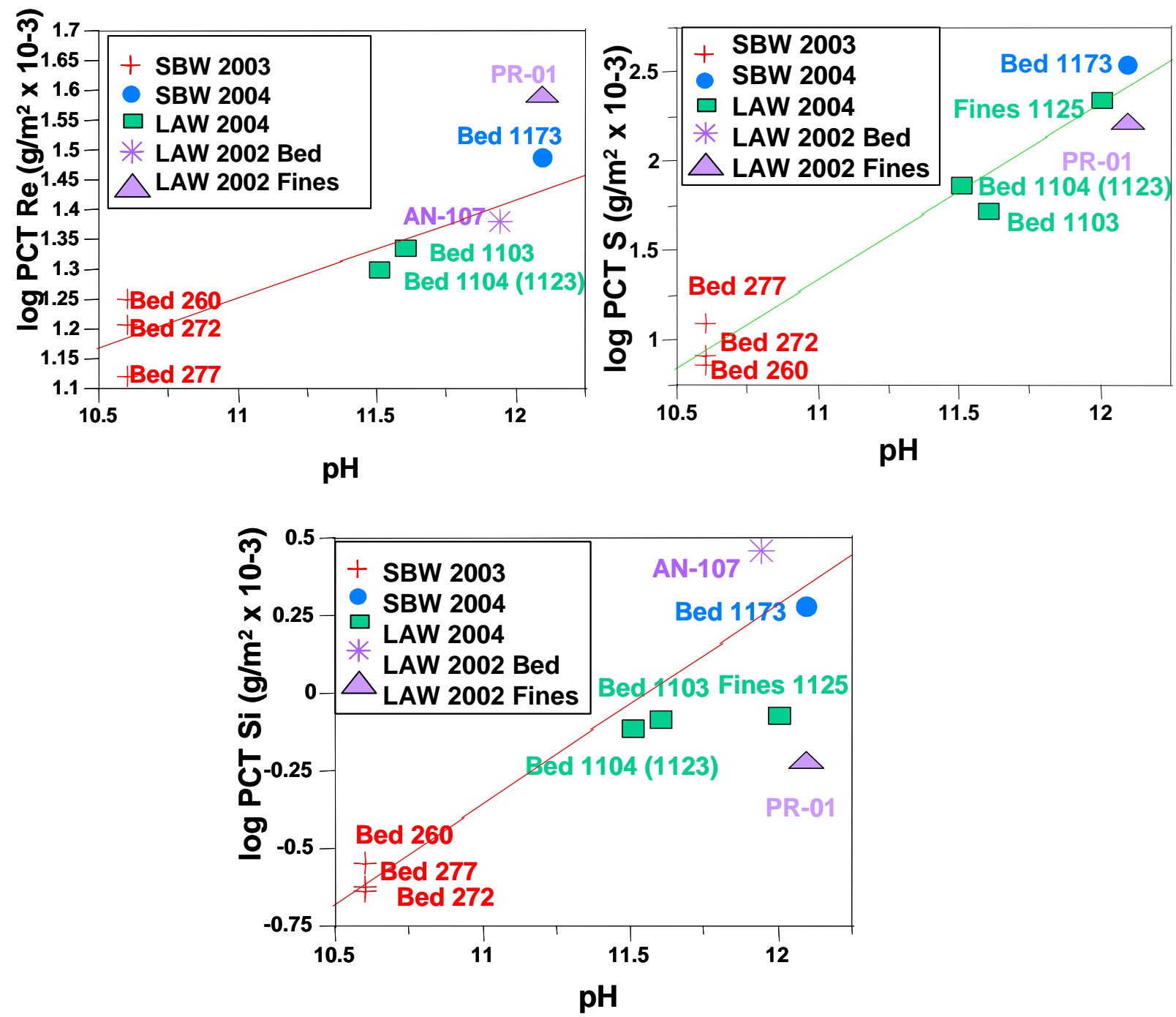

Figure 18. Leachate $\mathrm{Re}, \mathrm{S}$, and $\mathrm{Si}$ concentrations as a function of the $\mathrm{pH}$ of the final leachate. 
During SPFT testing of FBSR product made with AN-107 (Envelope C) in 2003 McGrail, et. al. [98] used different leachate buffers which contained nitric acid instead of the boratechloride-hydroxide buffers recommended in the ASTM procedure (ASTM 1662 - see Appendix D). While the use of $\mathrm{HNO}_{3}$ may not be problematic for glass waste forms, which are primarily made under oxidizing conditions, it may be problematic for either glasses or FBSR product made under reducing conditions as the $\mathrm{HNO}_{3}$ in the buffers is a strong oxidant. Thus testing in $\mathrm{HNO}_{3}$ buffers should be considered aggressive for glasses or mineral waste forms that are reduced, i.e. the leachate response may overestimate the waste form dissolution, or the ASTM recommended buffers should be used. Even the ASTM buffers need to be used with some caution for some elements such as Re (depending on the oxidation state of the $\mathrm{Re}$ ), because aqueous complexes such as $\mathrm{ReCl}_{4}{ }^{\circ}$ may form [102]. Even so, the SPFT FBSR testing to date with the aggressive $\mathrm{HNO}_{3}$ buffers indicated that the FBSR product was two orders of magnitude more durable than glass.

In the testing performed by McGrail et. al. [98] the assumption of incongruent leaching was applied, i.e. $\mathrm{S}$ and Re dissolution represent the dissolution of the sodalite/nosean phases while the dissolution of $\mathrm{Na}, \mathrm{Si}$, and $\mathrm{Al}$ represent the dissolution of the nepheline component of the FBSR products. By subtracting the dissolution rate of the nosean phase (based on $\mathrm{S}$ or $\mathrm{Re}$ ) from the dissolution rates of $\mathrm{Na}, \mathrm{Al}$, and $\mathrm{Si}$ and recalculating a residual dissolution rate for $\mathrm{Na}, \mathrm{Al}$, and $\mathrm{Si}$ dissolution, McGrail, et. al. calculated a $\mathrm{pH}$ dependence of the dissolution reaction order $(\eta)$ for nepheline dissolution of 0.25 at $90^{\circ} \mathrm{C}($ Table $\mathrm{V})$.

The researchers at SRNL $[97,99,101]$ tested Hanford LAW Envelope A FBSR product in 2004 and used the same buffers as McGrail et.al. to facilitate comparisons between the two studies, but employed higher flow rates. Using the same incongruent leaching assumptions made by McGrail et. al. [98] on the Hanford Envelope A wastes, Jantzen [101] generated a for the dissolution of nosean and nepheline at $90^{\circ} \mathrm{C}$ and the calculated a reaction order $(\eta)$ of 0.22 for $\mathrm{Na}, \mathrm{Al}$, and $\mathrm{Si}$ in agreement with the value of $\eta=0.25$ determined by McGrail for LAW Envelope C FBSR product (Table V).

During the SRNL studies it was noted that all of the mineral species present in the FBSR product (nepheline, nosean, and sodalite) share the same bonding in terms of the aluminosilicate matrix (see Figure 7, Figure 8, Figure 9, Figure 12, Figure 13) and are all members of the feldspathoid mineral family. Based on this structural information an alternate incongruent leaching hypothesis was modeled. All the cage structured feldspathoid minerals share the basic structural framework formula, i.e., $\left[\mathrm{NaAlSiO}_{4}\right]_{6}$. In this approach the $\mathrm{S}$ and Re are assumed in the nosean phase and assumed to represent the dissolution of this phase, but the nepheline-like structural units that form the structure of the nosean phase $\mathrm{Na}\left[\mathrm{AlSiO}_{4}\right]$ leach congruently with the $\mathrm{Na}\left[\mathrm{AlSiO}_{4}\right]$ structural units in the nepheline phases. In other words, the $\operatorname{Re}\left(\mathrm{Tc}^{99}\right)$ and $\mathrm{S}$ cannot be released from the cage until part of the structural units of the cage themselves degrade. Using this alternate incongruent leaching approach, a nosean dissolution reaction order $(\eta)$ is 0.16 , based on Re release and $\eta=0.13$ is calculated based on the $\mathrm{S}$ release (Table V). The dissolution rates for $\mathrm{Si}$ from the $\mathrm{Na}\left[\mathrm{AlSiO}_{4}\right]$ structures at various temperatures are given in Table $\mathrm{V}$ and demonstrate that the FBSR product appears to leach congruently as the common structural framework of all the phases, e.g., $\left[\mathrm{NaAlSiO}_{4}\right]_{6}$, break down at $\mathrm{pH}$ values $>8.5$, the $\mathrm{pH}$ of the aqueous equilibrium 
boundary between amorphous $\mathrm{Al}(\mathrm{OH})_{3}$ gel and the aqueous species $\mathrm{Al}(\mathrm{OH})_{4}{ }^{-}$[103]. The data from this congruent matrix dissolution hypothesis indicates that the dissolution rate $(\eta)$ and the activation energies for dissolution for the FBSR product agreed with the available rate and activation energy data for natural single crystal nepheline based on Si release. $[104,105]$

When the reaction order for nepheline dissolution determined for the LAW nepheline components in the SRNL study and in the McGrail et al [98] study are compared to that measured by Tole $[104,105]$ on single crystal natural nepheline (Table V) it can be concluded that the nepheline reaction orders measured in the SRNL study for $\mathrm{Na}\left[\mathrm{AlSiO}_{4}\right]$ structural units, are in agreement with the data of Tole $(\eta=0.13)$ for nepheline and the data of Morss et.al [42] for glass bonded sodalite ceramic waste forms $(\eta=0.17)$ at comparable temperatures $\left(80-90^{\circ} \mathrm{C}\right)$, rather than the data of McGrail et. al. [98].

In addition, the reaction order measured for nosean dissolution (based on $\mathrm{S}$ and $\mathrm{Re}$ ) in this study are also comparable to the values measured by Tole for phase pure nepheline. All the reaction orders measured on LAW nepheline FBSR product in this study and in the McGrail study [98] are lower than the reaction order measured by Hamilton, et.al. [31] on nepheline glass. It should be noted that the reaction order given by Hamilton is based on Si release and is comparable to $\eta=0.40$ measured on a simple 5 component High Level Waste glass at $70^{\circ} \mathrm{C}$ [106].

During 2004 and 2007, the time interval between the McGrail study [98] and the SRNL study [101], unreacted kaolin cores in the FBSR mineral waste form were found by Lorier, et. al. [107] during SEM analysis. Unpublished SRNL data shown in Figure 20 demonstrates that these cores are enriched in $\mathrm{Al}$ over $\mathrm{Si}$ and have $\mathrm{TiO}_{2}$ impurities ubiquitous of kaolin type clays. Thus it is possible that $\mathrm{Al}(\mathrm{OH})_{3}$ or other aluminum hydrates might be forming colloidal species from dissolution of the metakaolin and/or other aluminosilicate species as noted by Tole $[104,105]$. These data indicate that the leaching of the $\mathrm{Na}\left[\mathrm{AlSiO}_{4}\right]$ framework structure of the nepheline and nosean structures may be similar, while the leach rate of alumina may be complicated by precipitation of colloidal species. This is also in agreement with the alumina buffering mechanism determined by Jantzen and Pareizs during PCT testing of the FBSR product $[94,96,97]$ and the importance of the $\mathrm{Al}(\mathrm{OH})_{4}^{-}$complex in the leachates of French HLW glasses, i.e. small changes in the activity of the $\mathrm{Al}(\mathrm{OH})_{4}^{-}$aqueous species had a major impact on the French HLW glass dissolution kinetics. [90] 


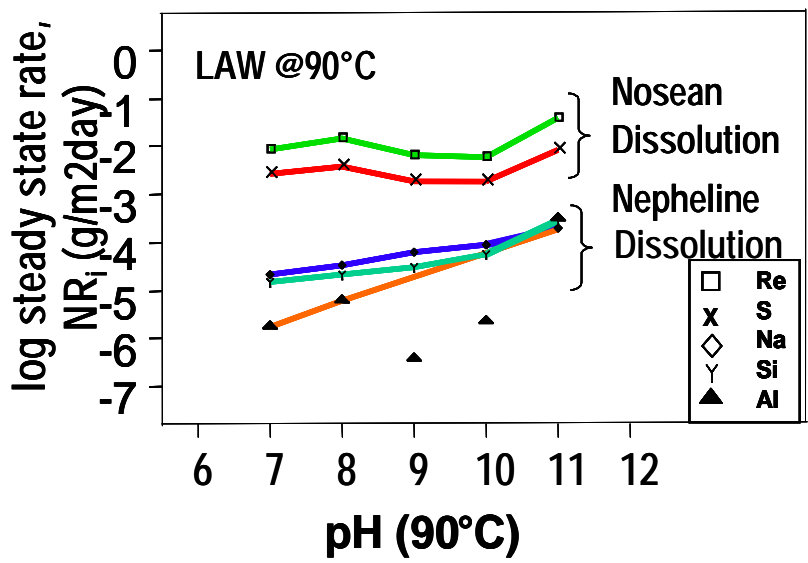

(a)

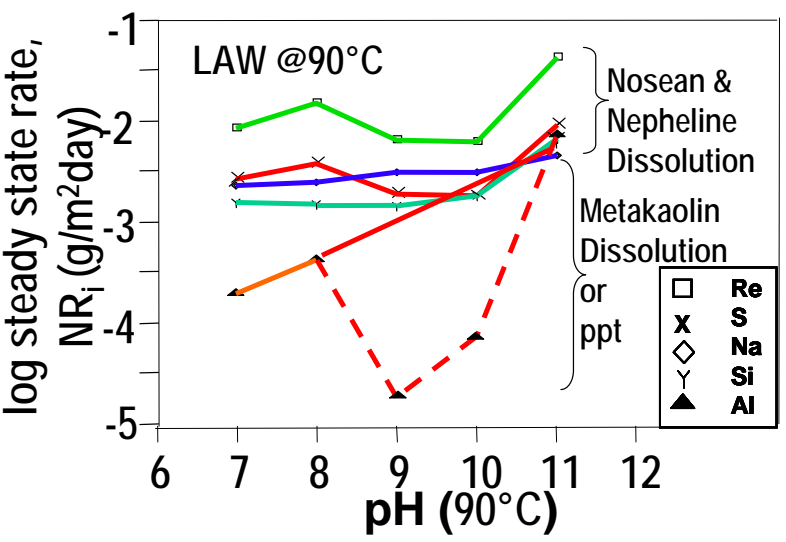

(b)

Figure 19. Interpretation of dissolution in the Hanford LAW FBSR mineral waste forms determined from SPFT testing at high flow rates.

Table V. Reaction order in $\mathrm{pH}$ for nosean, crystalline nepheline, and nepheline glass

\begin{tabular}{|l|c|c|c|c|}
\hline \multirow{2}{*}{ pH Range 7-11 } & Nosean/Sodalite & \multicolumn{3}{|c|}{ Nepheline } \\
\cline { 2 - 5 } & $\mathbf{9 0} \mathbf{C}$ & $\mathbf{2 5}^{\circ} \mathbf{C}$ & $\mathbf{7 0}^{\circ} \mathbf{C}$ & $\mathbf{8 0 - 9 0}^{\circ} \mathbf{C}$ \\
\hline LAW Envelope A [101] & $\begin{array}{c}0.13(\mathrm{~S}) \\
0.16(\mathrm{Re})\end{array}$ & $0.23^{*}$ & $0.17^{*}$ & $0.13^{*}$ \\
\hline LAW Envelope C [98] & N.D. & N.D. & N.D. & $0.25^{*}$ \\
\hline Natural Nepheline [104,105] & N.D. & $0.2^{*}$ & N.D. & $0.13^{*}$ \\
\hline Nepheline Glass [31] & N.D. & N.D. & N.D. & $0.43^{*}$ \\
\hline
\end{tabular}

* Based on Si release 


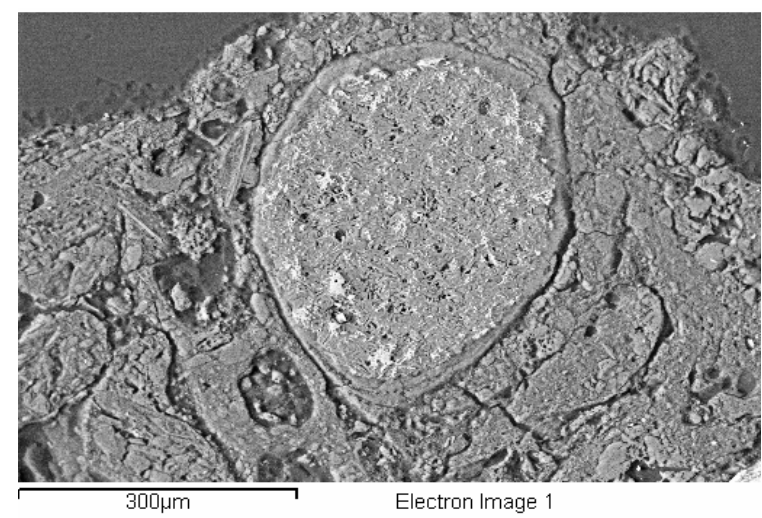

(a)

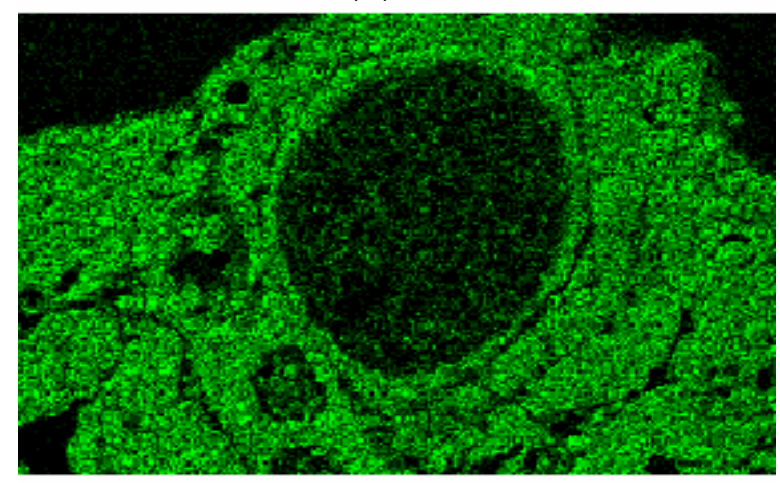

Si Ka1

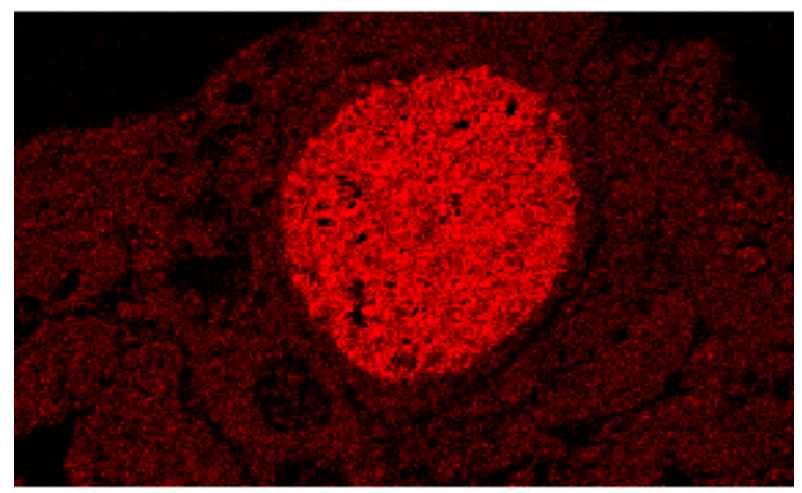

Al Ka1

(b)

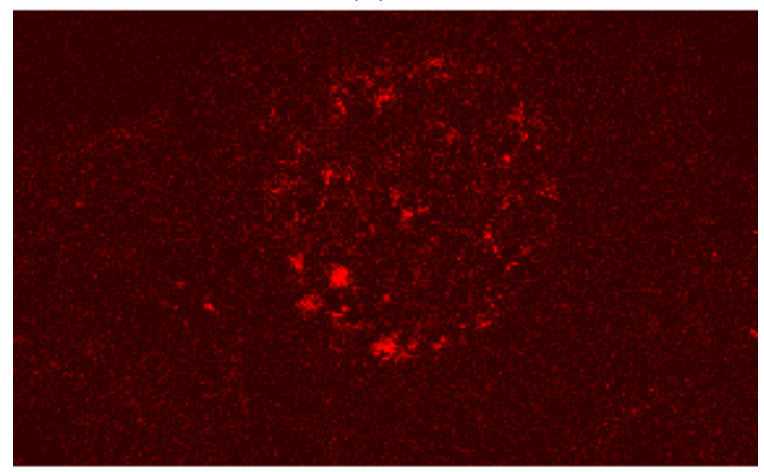

Ti Ka1

(c)

(d)

Figure 20. Scanning Electron Microscopy (SEM) and Energy Dispersive Analysis by X-Ray (EDAX) of a clay core of an FBSR granule. The core is depleted in Si, enriched in $\mathrm{Al}$, and has the ubiquitous $\mathrm{TiO}_{2}$ impurities normally associated with kaolin type clays. 


\subsection{How FBSR Durability Testing Compares to the Hanford Glass Testing}

During durability testing with the ASTM C1285 Product Consistency Test (PCT) [94,94,96,97], the ASTM C1662 Single Pass Flow Through Test (SPFT) [97, 98,99,100,101], and the PNNL PUF test [98] at PNNL and SRNL, the FBSR granular mineral product has been shown to be as durable as (in $\mathrm{g} / \mathrm{L}$ ) or more durable (in $\mathrm{g} / \mathrm{m}^{2}$ day) than Hanford's LAW glass. The FBSR products tested include the Hanford LAW Envelope A and Envelope C simulants and they both performed equally as well during PCT and SPFT testing and during subsequent performance assessment modeling.[87,98,99] During these tests the dissolution of the surrogate radionuclides, i.e. non-radioactive $\mathrm{Cs}$, $\mathrm{Re}$ (for $\mathrm{Tc}^{99}$ ) and I, were monitored in order to determine if leaching was congruent (as in LAW glass) or incongruent.

The PCT test results demonstrated that an Al-buffering mechanism was impacting the leachate $\mathrm{pH}$ and controlling the release of alkali $(\mathrm{Na}$ and $\mathrm{Cs}$ ) and that the $\mathrm{pH}$ was controlling the release of the other constituents like Re, S, and Si (Figure 17 and Figure 18). This is due to the high aluminosilicate content of the mineral products which provides a natural aluminosilicate buffering mechanism that inhibits leaching and is known to occur in nature during weathering of aluminosilicate mineral analogs [108]. While HLW glasses produced in the United States do not normally contain high alumina contents (high alumina glasses are too viscous to process), such an aluminosilicate buffering mechanism has been observed by the French.[90] The leachate buffering mechanism and the fact that the FBSR mineral product contains the radionuclides in a structure that has long range order makes the FBSR mineral products as durable or more durable than glasses of a similar composition.

The results of the PCT test also indicated that the PCT is less sensitive to the REDOX state of the waste form than SPFT testing (Figure 21). This is likely because the PCT test is static and the SPFT test is a flowing test. In addition, the ASTM Type I water used in the PCT is not as oxidizing (contains some dissolved oxygen but steel vessels represent a closed system) as the buffers used in the SPFT testing (Table VI). Thus during SPFT testing of reduced waste forms (glass or mineral), care should be taken with the choice of buffers, especially when monitoring a REDOX sensitive element such as Re that can exist in the +4 state as $\mathrm{ReO}_{2}$ or $\mathrm{ReS}_{2}$, as well as in the oxidized +7 state as $\mathrm{NaReO}_{4}$. In this case the PCT test gives a much more consistent Re release for a variety of LAW and SBW FBSR mineral waste forms than does the SPFT. 


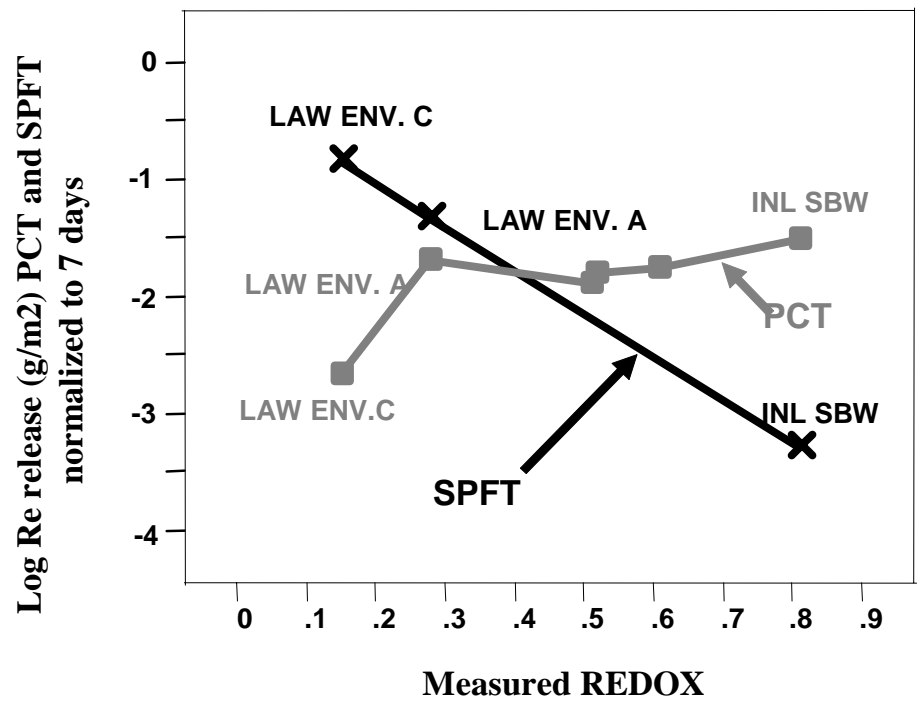

Figure 21. Comparison of the Re release from LAW Envelope C, LAW Envelope A, and INL SBW mineral waste forms to measured waste form REDOX.

The SPFT and PUF testing performed by PNNL indicates that the FBSR mineral product is more durable than LAW glass by $\sim 2$ orders of magnitude $[98,99]$. While PNNL researchers assumed an incongruent dissolution mechanism for the FBSR mineral product, SRNL assumed a congruent dissolution mechanism. SRNL's congruent data interpretation agreed with the data of Tole $[104,105]$ for nepheline dissolution $(\eta=0.13)$ and the data of Morss et.al [42] for glass bonded sodalite ceramic waste form dissolution $(\eta=0.17)$ at comparable temperatures $\left(80-90^{\circ} \mathrm{C}\right)$, rather than the data derived by McGrail et. al., assuming an incongruent dissolution mechanism [98]. If the incongruent assumption is applied to the SRNL data, then the same conclusions can be drawn as in the McGrail et. al. study. Given that the SPFT data interpretation can indicate that dissolution of the FBSR mineral products may be congruent or incongruent, more testing is warranted. In the meantime, the release of $\mathrm{Cs}, \mathrm{Re}$, I etc from the FBSR product should be compared to the release of $\mathrm{Na}, \mathrm{B}$, or Li from LAW glass since the latter elements represent the "maximum radionuclide" release from LAW glass.

It should also be noted that the FBSR mineral waste forms meet the Universal Treatment Standards (UTS) [95,96,97] as does HLW borosilicate glass.[109] 


\subsection{ACKNOWLEDGEMENTS}

The authors would like to gratefully acknowledge the Work for Others (WFO) agreement (WFO-08-003) between Savannah River National Laboratory (SRNL) and THOR Treatment Technologies LLC (TTT) and the U.S. Department of Energy under Contract No. DE-AC0996SR18500 and DE-AC09-08SR22470 and for supporting the compilation of this review. 


\section{APPENDIX A-VITRIFIED WASTE FORM DURABILITY AND REDOX}

\section{A.1 Glass Durability and the Homogeneity Assumption}

For single phase waste forms with no grain boundaries, e.g. a glass without crystalline grain boundaries or a single phase mineral waste form, the durability measured can be attributed to the elements and/or radionuclides contained in that single phase. If a glass undergoes glassin-glass phase separation (like oil in water), then two or more glassy phases can co-exist and certain radionuclides will partition to each of the glassy phases (Figure 22). In addition, phase boundaries occur between the different glassy phases and one phase usually leaches selectively compared to the others (Figure 22) and the radionuclides are distributed amongst the more durable and less durable phases. If a glass crystallizes, it creates a grain boundary, which can undergo accelerated grain boundary dissolution (Figure 23). In other words the overall durability can be expressed as:

Equation 4

$\sum$ Durability $=\underbrace{\text { Homogeneousresponse }}_{\text {Glass }}+\underbrace{\text { Crystal }+ \text { Grain Boundaryresponse }}_{\text {Crystal A+Crystal } B+\text { Crstal } X}+\underbrace{\text { PhaseSeparationresponse }}_{\text {Glass-in-Glass }}$

To prevent having to account for and model the different leach rates from the secondary glassy and crystalline phases, waste form producers go to great lengths to formulate homogeneous (single phase) glasses so the additional terms in Equation 4 do not have to be modeled.[110,111,112] In addition, a waste form must be studied to determine the maximum rate of radionuclide release. The following quote from ASTM C1285 [66] describes the rationale:

"Since many radioactive species are present at very low concentrations, e.g. $\mathrm{Tc}^{99}$ is present at $\sim 4.1 \times 10^{-4}$ weight $\%$ in borosilicate waste forms, major glass forming elements are often used as indicators. For example, it has been shown that boron, lithium, and sodium are released at the same maximum normalized concentration as $\mathrm{Tc}^{99}$. Therefore, for borosilicate glass waste forms, the leachates are routinely analyzed for boron, lithium, and sodium if these elements are present at $>1$ mass $\%$ in the glass. Additional mechanistic information about high level borosilicate waste glass durability is gained by analyzing for other elements present at $>1$ weight $\%$ in the glass. Extensive testing $[40,41,67,68,69,70,71,72,73,74,75]$ of any glass or glass ceramic waste form must be performed in order to determine what these elements are."

When dealing with glass ceramics or devitrified glasses, the second term in Equation 4 must be accounted for. This is done by choosing a unique element from each phase (glass and crystal) in the final waste form, e.g. for glass bonded ceramics unique elements and/or radionuclides are monitored from the glassy phase, the halide phases, and the sodalite phase: 
- $\mathrm{Si}, \mathrm{Al}, \mathrm{Na}, \mathrm{Li}$ (sodalite and glass)

- B (glass)

- $\mathrm{Cl}$ (sodalite and halite)

The only manner in which a crystalline phase does not have to be separately monitored is if the phase is shown, by extensive study, to be inert and not contain radionuclides. This rationale is also detailed in ASTM C1285 for glass bonded ceramics and devitrified HLW glasses.[66]

For crystalline (ceramic/mineral) waste forms that have an intergranular glassy phase because they have been formed at elevated temperatures where the cations and anions are mobile at the formation temperature, the approach is much the same: the first two terms in Equation 4 must be accounted for. This includes, but is not limited to, the following waste forms: SYNROC, Pu-ceramics, High Al-tailored ceramics, and supercalcines. [113,114,115, $116,117,118,119]$ In particular, it has been determined that waste impurities tend to stabilize in the intergranular glassy phase and result in elemental losses which are an order of magnitude greater for some radioactive waste species.[118] Therefore, if radionuclides have preferentially partitioned to one phase or to the intergranular phase at elevated temperatures, these elements must be directly monitored during a durability test. This rationale is also detailed in ASTM C1285 for glass bonded ceramics. [66]

For multiphase granular crystalline (ceramic/mineral) waste forms that are bound by a glassy, hydroceramic, geopolymer, or cementitious matrix, the approach would be similar if the binder is a homogeneous phase like glass, ceramicrete, or geopolymers. Cements and hydroceramic binders are multiphase and the presence of multiple phases in the binder complicates the durability response if any radionuclides sorbed onto or into the binder phases. Therefore, the radionuclide partitioning between a single phase binder, which has been shown to be inert, and a granular waste form is easier to study than multi-phase binders that may have interactions with the waste form.

Vitreous waste forms, including homogeneous glasses, phase separated glasses, glassceramics, and devitrified glasses, as well as crystalline (ceramic/mineral) waste forms may be evaluated by a number of different durability tests and expressed in a variety of different units. Many of these tests have been made into ASTM standards since 1987 or are under discussion as durability standards by ASTM Committee C26 (Nuclear Fuel Cycle). 


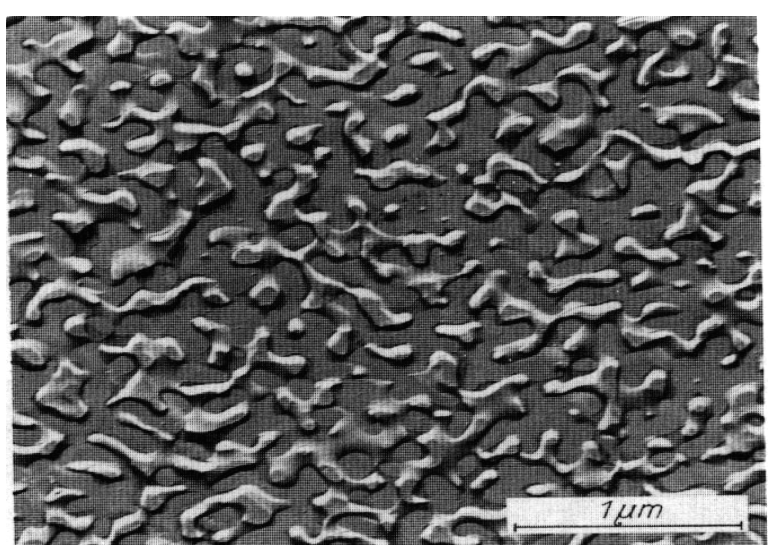

(a) Amorphous Type A phase separation in sodium borosilicate glass

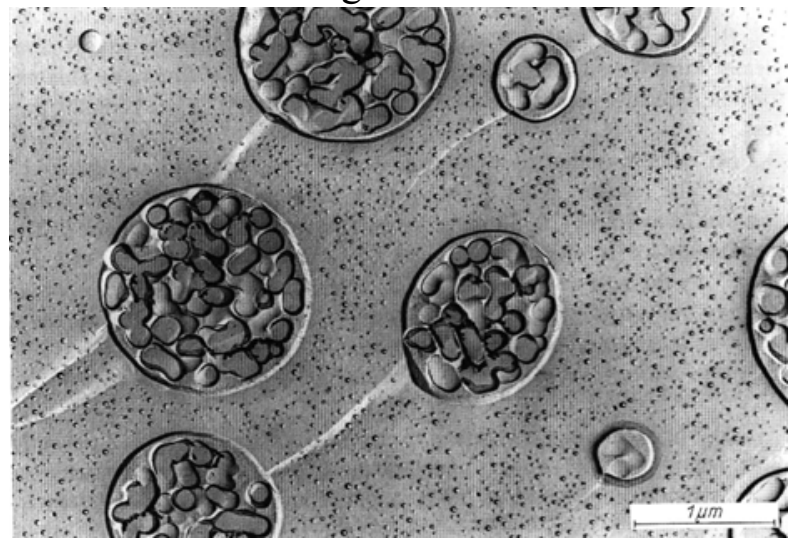

(c) Amorphous Type $\mathrm{C}$ phase separation in sodium borosilicate glass

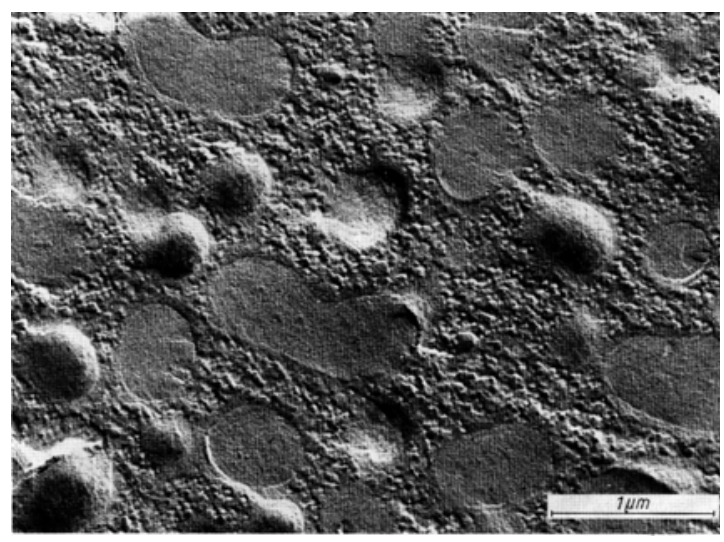

(b) Amorphous Type B phase separation in sodium borosilicate glass

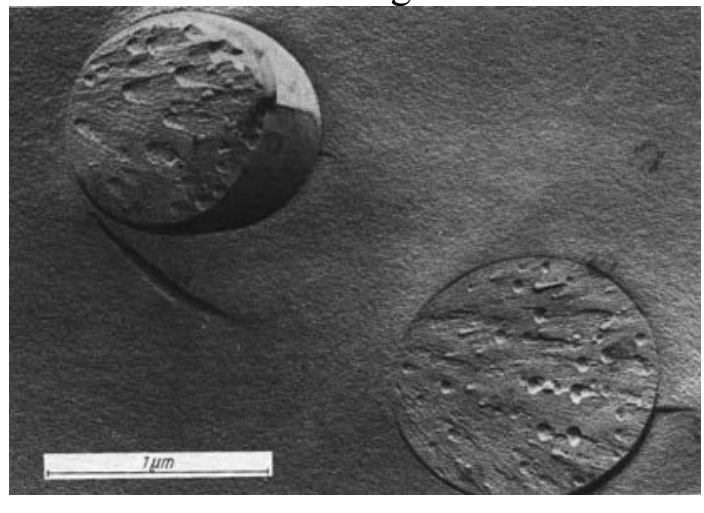

(d) Crystalline phase separation in phosphate-rich sodium borosilicate glass

Figure 22. (a) Example of Type A glass-in-glass phase separation where both phases are continuous and interconnected and durability is governed by the least durable phase; (b) Example of Type B glass-in-glass phase separation where a silica-rich phase is dispersed as droplets in a continuous matrix of alkali-borate and the durability is governed by the continuous matrix that is poorly durable; (c) Example of Type $\mathrm{C}$ glass-in-glass phase separation where an alkali-borate phase is dispersed as droplets in a continuous matrix of silica-rich phase and the durability is governed by the continuous phase that is highly durable; (d) Example of crystalline phase separation of a calcium phosphate-rich phase in sodium borosilicate glass. From Vogel.[33] 


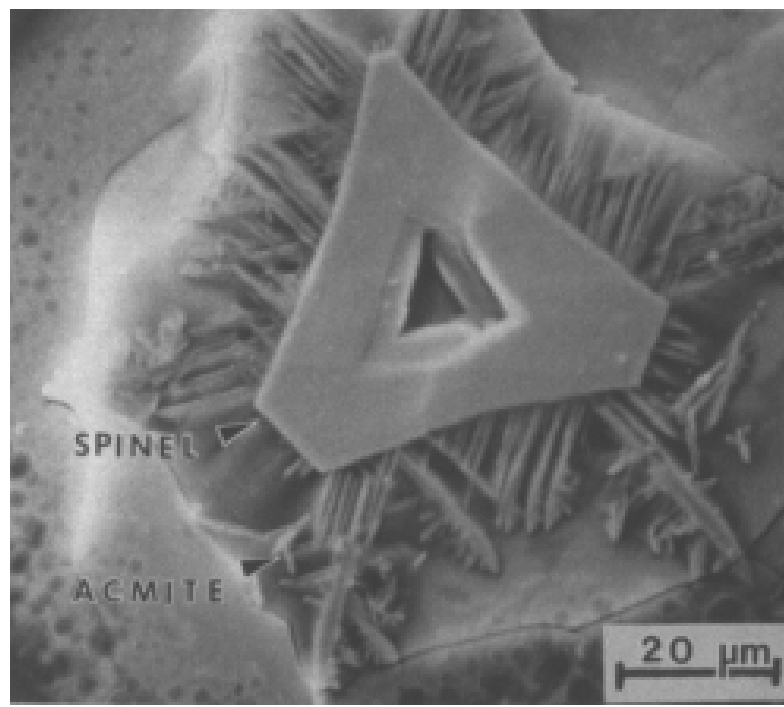

(a) Devitrified glass covered by leached layer after monolithic durability testing.

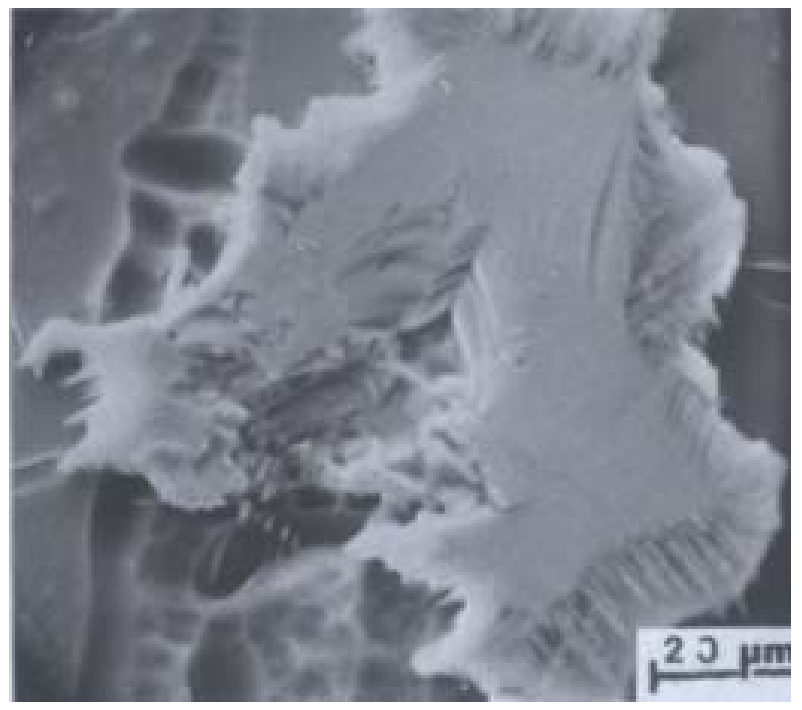

(b) Devitrified glass after leached layer has been removed with tape after monolithic durability testing exposing selective grain boundary dissolution along edges of acmite crystals and underneath the spinel crystal.

Figure 23. Leaching of a simulated SRNL HLW devitrified waste glass showing a triangular spinel crystal with acmite needles growing out of it devitrified HLW borosilicate glass. [120]

\section{A.2 REDOX Effects on Glass Durability}

Knowing the REDOX speciation of hazardous species and radionuclides in a HLW glass can help (1) determine the durability mechanism by which an individual component is released and (2) determine which leachants (especially buffered leachants that may contain inappropriate oxidizers or complexants) are appropriate for a given durability test.

In 1984-1995 Jantzen and Plodinec [121,122,123,124,125] demonstrated that simulated HLW waste glasses containing reduced $\mathrm{Fe}^{2+}$ were less durable than oxidized glasses containing an equivalent amount of $\mathrm{Fe}^{3+}$. Oxidized iron was found to be associated with improved glass durability, while the presence of reduced $\mathrm{Fe}^{2+}$ indicated decreased overall glass durability. This was confirmed with natural analog glasses such as natural basalt glass, tektite (meteorite) glasses, and obsidian. In addition, lunar glass simulants made under both oxidizing and reduced melt conditions, and iron enriched basalt glasses used for the clean-up of Three Mile Island [126] were studied. Because the melt REDOX can impact the oxidation state of multivalent contaminants and thus the atomic bonding (coordination polyhedra) of a given contaminant, the REDOX impacts the durability of the glass in terms of the release of those contaminants, e.g. $\mathrm{Cr}^{+6}$ leaches more rapidly than $\mathrm{Cr}^{+3}$. In order to be able to determine the oxidation states of all the multivalent species in a waste glass, an electromotive force (EMF) series was developed for HLW glasses so that the impacts of the multivalent speciation between oxidized and reduced glasses could be assessed against the glass 
durability performance (Figure 24). In other words, glasses made in melters with reducing oxygen fugacities could be compared to those made in melters with oxidizing fugacities, e.g. with bubblers. For this reason, the Environmental Assessment (EA) benchmark glass standard for HLW glass durability has a REDOX ratio of $\mathrm{Fe}^{2+} / \Sigma \mathrm{Fe}$ of $0.22[127,128]$.

The HLW glasses made at the Defense Waste Processing Facility (DWPF) are made at an $\mathrm{Fe}^{+2} / \Sigma \mathrm{Fe}$ ratio of $\sim 0.2$ and contain $\sim 10 \mathrm{wt} \%$ total $\mathrm{Fe}$. This measured iron REDOX ratio indicates effective oxygen fugacities in logarithm base 10 of -2 to -7 in the melter. At the more oxidized melt fugacity of $10^{-2}$, Figure 24 predicts that $10 \%$ of any $U$ present will be present as $\mathrm{U}^{+5}$, while the rest will remain as $\mathrm{U}^{+6} ; 35 \%$ of the copper will be $\mathrm{Cu}^{+1} ; 70 \%$ of the cerium will be present as $\mathrm{Ce}^{+3} ; 90 \%$ of any silver present will be metallic; $97 \%$ of any manganese present will be divalent, as will all of the $\mathrm{Ni}$ and $\mathrm{Co} ; 90 \%$ of the chromium will be present as $\mathrm{Cr}^{+3}$; and $90 \%$ of any antimony present will be $\mathrm{Sb}^{+3}$.

The REDOX ratio of the Environmental Assessment (EA) glass indicates that it was made at a $\log 10$ oxygen fugacity of -4.5 . At this oxygen fugacity, $10 \%$ of the $U$ will be $U^{+4}, \sim 50 \%$ will be $\mathrm{U}^{+5}$, and the remainder will be $\mathrm{U}^{+6} ; 80 \%$ of the copper will be $\mathrm{Cu}^{+1} ; 80 \%$ of the cerium will be present as $\mathrm{Ce}^{+3} ; 98 \%$ of any silver present will be metallic; $>99 \%$ of any manganese present will be divalent, as will all of the Ni and $\mathrm{Co} ; 100 \%$ of the chromium will be present as $\mathrm{Cr}^{+3}$; and $100 \%$ of any antimony present will be $\mathrm{Sb}^{+3}$. At both of these REDOX ratios $\mathrm{Ti}^{+4}, \mathrm{Sn}^{+4}$, and $\mathrm{Mo}^{+6}$, are the dominant valences present (Figure 24). Additional data published by Schreiber, et al. [129] indicates that 50-95\% of any As will be present as $\mathrm{As}^{3+}$ and $95-100 \%$ of any $\mathrm{Se}$ will be present as $\mathrm{Se}^{+4}$. In a bubbled melter where the oxygen fugacity is $\sim 0$ many of the multivalent species will be fully oxidized, e.g. uranium will be $90 \% \mathrm{U}^{+6}$; chromium will be $100 \% \mathrm{Cr}^{+6}$; antimony will be $50 \% \mathrm{Sb}^{+5}$; and arsenic will be $95 \% \mathrm{As}^{+5}$. These oxidized species are more prone to leaching. In a reduced glass, oxidative dissolution must occur for the contaminants to be released, i.e. the water must be oxidizing or carry significant oxygen to oxidize the contaminants. If the contaminant species is already oxidized then dissolution in any type of water, oxygenated or deoxygenated, is more easily achieved. 
PERCENTAGE OF REDOX COUPLE WN REDUCED STATE

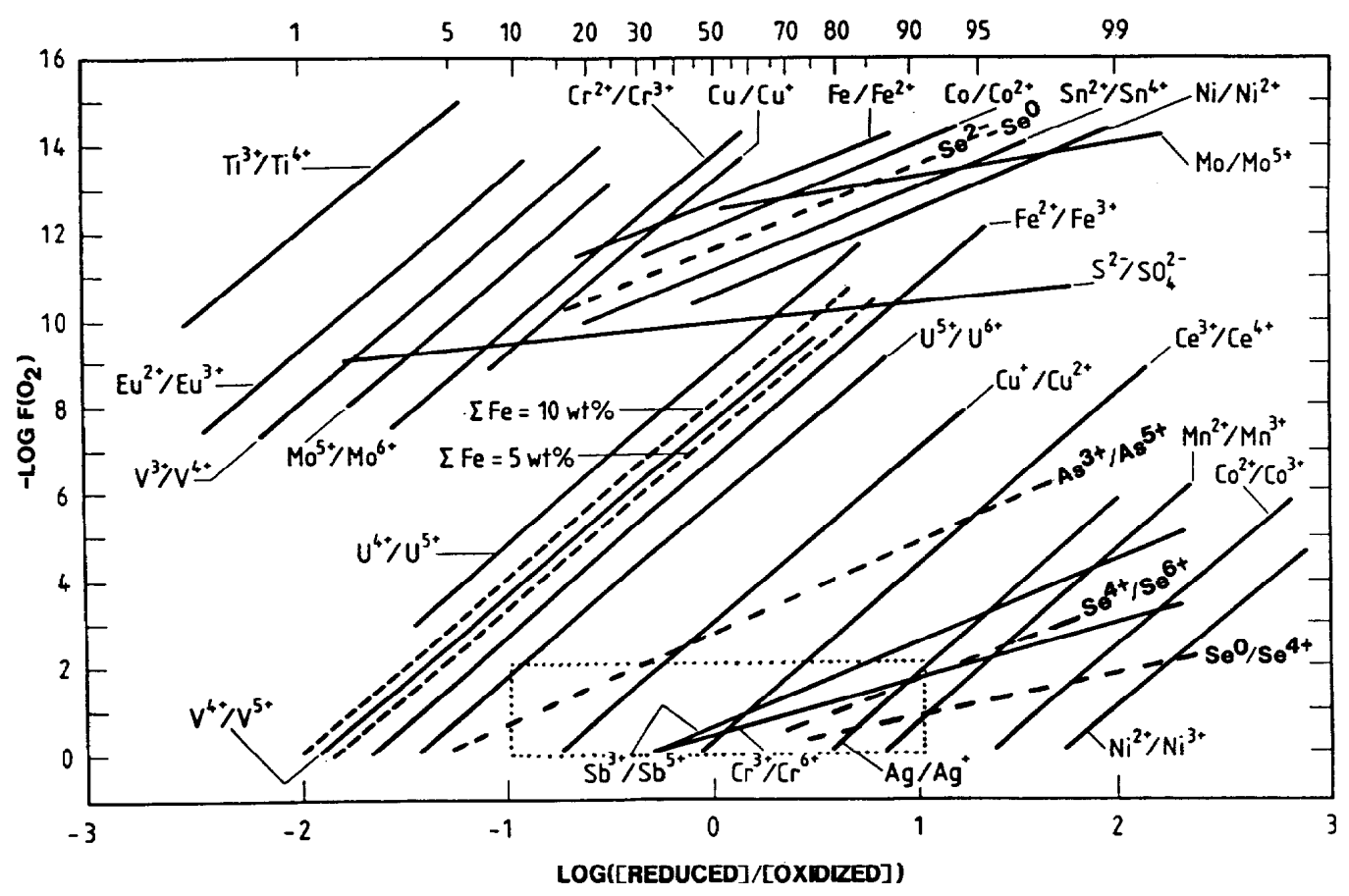

Figure 24. Relation of the imposed oxygen fugacity $\left(-\log f_{\mathrm{O}_{2}}\right)$ to the analyzed REDOX ratio expressed as $\log \mathrm{Fe}^{2+} / \Sigma \mathrm{Fe}$ of multivalent elements doped into SRL-131 melt at $1150^{\circ} \mathrm{C}$. [130] 


\section{APPENDIX B-FLUIDIZED BED STEAM REFORMING PROCESS}

\section{B.1 Commercialization}

Studsvik built and tested a commercial Low-Level Radioactive Waste (LLRW) FBSR Processing Facility in Erwin, TN, in 1999 [14]. In January 2000, commercial operation commenced.[131] The Studsvik Processing Facility (SPF) has the capability to process a wide variety of solid and liquid LLRW streams including: ion exchange resins, charcoal, graphite, sludge, oils, solvents, and cleaning solutions at radiation levels of up to $400 \mathrm{R} / \mathrm{hr}$. The ion exchange resins are from commercial nuclear power plants and contain highly radioactive $\mathrm{Cs}^{137}$ and $\mathrm{Co}^{60}$. The licensed and heavily shielded SPF can receive and process liquid and solid LLRWs with high water and/or organic content. At Erwin the equipment vessels are designed to be emptied and cleaned remotely if needed to radiation levels that allow contact maintenance to be performed.

The Erwin facility employs the THermal Organic Reduction $\left(\mathrm{THOR}^{\circledR}\right)$ process, developed by Studsvik, which utilizes pyrolysis ${ }^{*} /$ steam reforming technology. $\mathrm{THOR}^{\circledR}$ processes a wide variety of LLRW's in the unique, moderate temperature, dual-stage, pyrolysis/reforming, fluidized bed treatment system. The reforming process has demonstrated effectiveness in destroying organics and separating sulfur and halogens from inorganic waste materials. Of special relevance is the capability of the $\mathrm{THOR}^{\circledR}$ technology to convert nitrates and nitrites to $\mathrm{N}_{2}$ and sodium salts to sodium compounds that are suitable for direct disposal and/or subsequent vitrification.

\section{B.2 Pilot Scale and Engineering Scale Demonstrations}

In late 2001 a mineralized sodium aluminosilicate waste form was produced by $\mathrm{THOR}^{\circledR}$ in a pilot scale FBSR. Hanford's basic pH sodium-bearing LAW [34] known as AN-107, which contained high sulfate and high concentrations of organics, was made into a mineralized NaAl-Si (NAS) product composed mainly of the feldspathoid minerals. The NAS minerals have cage and ring structures that accommodate the radionuclides [34]. Other pilot scale demonstrations in late 2001 showed that the AN-107 LAW waste could be transformed into carbonate, aluminate, or silicate products.

In November 2002, THOR ${ }^{\circledR}$ demonstrated FBSR processing of a carbonate waste solid for Idaho National Laboratory's (INL) acidic and radioactive Sodium-Bearing Waste (SBW) that met the Waste Isolation Pilot Plant (WIPP) Waste Acceptance Criteria (WAC).[132] Additional pilot scale demonstrations were performed at the Science Applications International Corporation (SAIC) Science \& Technology Application Research (STAR) Center in Idaho Falls, ID by INL and by THOR $^{\circledR}$ for SRNL on Savannah River Site (SRS) Tank 48 wastes, which contained tetraphenyl borate. The FBSR process was to destroy the organics in the Tank 48 waste, while producing a carbonate mineralized product for

* Pyrolysis chemically decomposes organic materials by heat in the absence of oxygen. 
subsequent vitrification.[133] In 2003 and 2004 several pilot scale demonstrations were completed at STAR by a team of INL, SRNL and THOR ${ }^{\circledR}$. Both carbonate and aluminosilicate waste forms were made from Hanford's LAW (Envelope A) waste and INL's Sodium Bearing Waste (SBW). Another 2004 pilot scale demonstration of SBW mineralization into feldspathoids was also performed [134], as well as a mineralization demonstration [135] with Hanford LAW simulant Envelope A.

Lastly, three engineering scale demonstrations were performed in 2006 and three in 2008 at the Hazen Research Inc (HRI) facility in Denver, CO. Three of the 2006 and one of the 2008 demonstrations produced sodium carbonate from SBW and SRS Tank 48 waste simulants. A fourth 2006 demonstration produced the feldspathoid minerals from an INL SBW waste simulant. Two 2008 demonstrations produced the feldspathoid mineral from LAW and LAW melter recycle (LAW-R) waste simulants. Additional tests are planned for 2009.

\section{B.3 Clean Air Act Compliance}

In the THOR ${ }^{\circledR}$ process, waste feed, superheated steam, and co-reactants are introduced into a fluidized bed steam reformer vessel, where liquids are evaporated, organics are decomposed, and reactive chemicals in the waste feed are fully converted to a stable waste product that incorporates essentially all of the radionuclides. The fluidized bed design of the steam reformer provides a large surface area for the waste to fully and efficiently react. Carbon and iron-based co-reactants (reductants) are used to convert nitrates and nitrites directly to nitrogen gas in the reformer. Clay or other inorganic co-reactants are added to the waste feed or bed to convert the radionuclides, alkali metals (cesium, rubidium, sodium and potassium), sulfates, halides (if any) and non-volatile heavy metals into an immobilized mineral product.

The FBSR process converts organic constituents to carbon dioxide and water vapor by a combination of steam reforming and oxidation reactions. In the FBSR, the organic compounds are pyrolyzed to $\mathrm{CO}_{2}$, while nitrate/nitrite species are converted to $\mathrm{N}_{2}$ through reactions with superheated steam.[34,136,137] The FBSR technology has been determined to be CAA compliant by Region IV Environmental Protection Agency (EPA). In addition, the FBSR process has been shown to be Hazardous Waste Combustor (HWC) Maximum Achievable Control Technology (MACT) compliant.[131,138]

The process operates safely at near ambient pressure ( +5 psig to -2 psig) and at moderate temperatures $\left(650-750^{\circ} \mathrm{C}\right)$. The steam reformer can be electrically heated (small units) or operated in an auto-thermal mode, whereby the energy needs are supplied by the incoming superheated steam and by the oxidation of organics from the waste and carbon reductants. For production scale units, auto-thermal steam reforming is the preferred mode of operation. A significant benefit of the FBSR process is that it produces zero-liquid releases. All water is released as water vapor.

Figure 25 provides a process flow diagram for a dual fluidized bed steam reforming process. The process flow diagram identifies each of the major system components that include the simulant liquid waste preparation and feed system, the fluidizing gas (FG) supply system, the 
denitration and mineralization reformer (DMR), the product receiver (PR), the hightemperature filter $(\mathrm{HTF})$, the carbon reduction reformer (CRR) and the off-gas treatment system. The process operations downstream of the DMR are necessary for CAA compliance.

In the DMR, the granular/particle bed material is fluidized with low-pressure superheated steam. The waste is mixed in a batch/feed tank with select co-reactants, including a mineralization additive, usually clay. The waste feed/co-reactant slurry is injected into the bottom of the fluidized bed just above the fluidizing gas (steam) distributors. Additional solid co-reactants, such as granular carbon, are added. A sub-stoichiometric quantity of oxygen is also added to the DMR bed to react with the carbon to produce process energy. The DMR is operated in strongly reducing conditions to facilitate high reduction of nitrates and nitrites to nitrogen gas. The CRR is operated under oxidizing condition by injection of oxygen into the upper zone of the fluidized bed. The oxidizing zone converts residual carbon reductants and organics into carbon dioxide and water vapor.

Among the reactions occurring in the DMR are the following:

- All liquids are evaporated.

- Cations in the waste feed are converted into a stable mineralized product, in the $(\mathrm{Na}, \mathrm{K}, \mathrm{Cs}, \mathrm{Rb})-\mathrm{Al}-\mathrm{Si}$ oxide systems; the mineralized product contains the radionuclides and inorganic elements in the waste feed stream.

- Nitrates and nitrites in the waste feed are converted into $\mathrm{N}_{2}$ by the carbon containing solid reductants.

- Organics are initially converted into light volatile hydrocarbons such as methane, as well as carbon monoxide, hydrogen, carbon dioxide, and water in the DMR.

- In the CRR, oxygen is injected to fully oxidize the gaseous constituents. The off-gas stream from the CRR consists mostly of water vapor, carbon dioxide, nitrogen, oxygen, fine particles of solid product, minor carbon particle carryover, and small quantities of acid gases (if any) not converted to a mineralized form in the reformer.

- The hazardous metal $\mathrm{Cr}$ is reduced to a non-hazardous valence state, e.g., $\mathrm{Cr}$ (VI) is reduced to $\mathrm{Cr}$ (III), which is chemically bound in the solid product. 
WSRC-STI-2008-00268

Revision 0

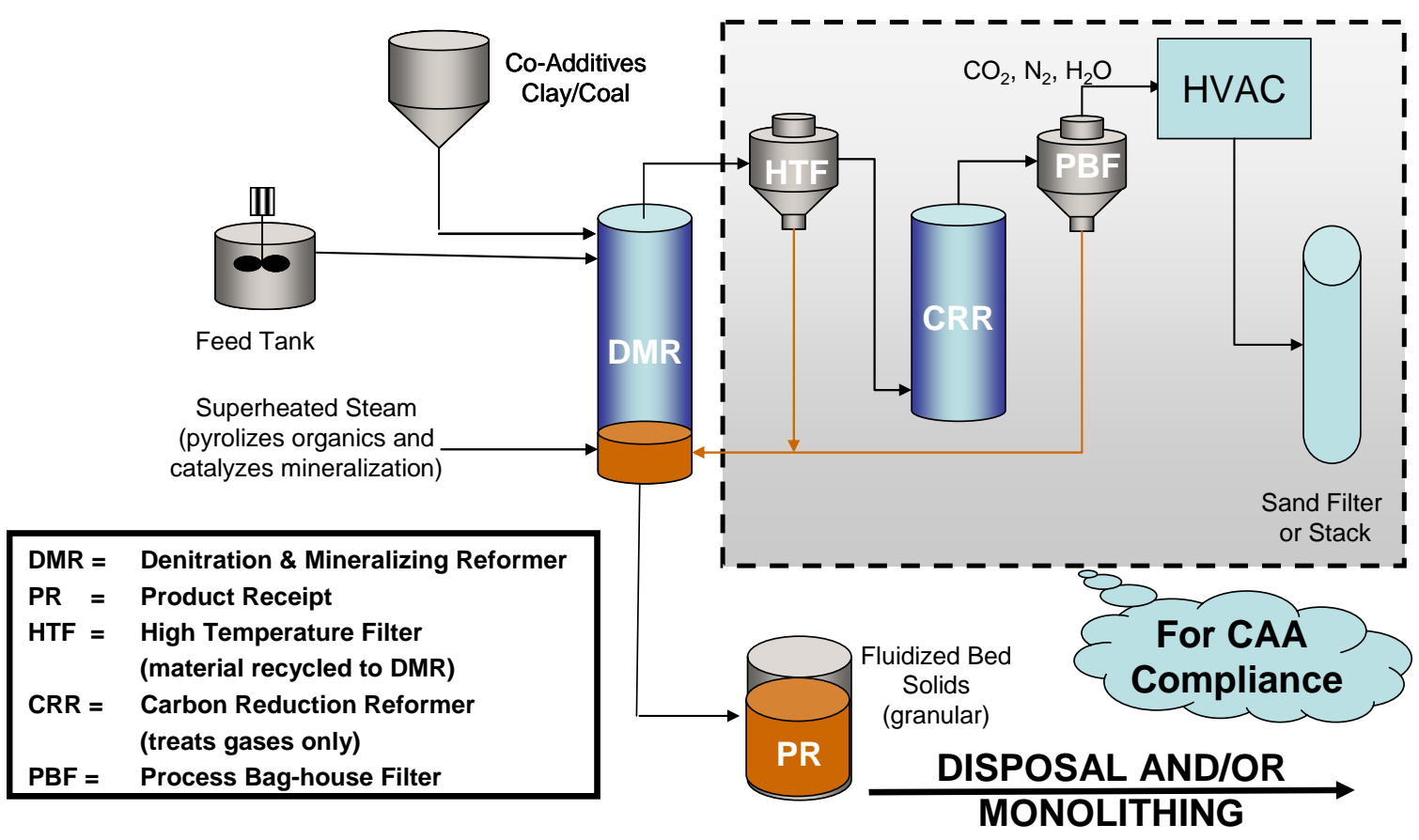

Figure 25. Simplified Dual Fluidized Bed Steam Reformer Flowsheet (Courtesy of THOR ${ }^{\circledR}$ Treatment Technologies, TTT). All unit operations beyond the Denitration and Mineralizing Reformer (DMR) are necessary to ensure that the off-gas is CAA compliant. 


\section{APPENDIX C-THE DURABILITY TEST PROTOCOLS CURRENTLY IN USE}

The summaries of the various durability tests currently in use for radioactive waste forms are given below. These are excerpts from Ebert [91]. It should be noted that ASTM C1220 (MCC-1), the ANL Drip test, the Vapor Hydration Test (VHT), and the Accelerated Leach Test (ALT), which is an improved version of ANSI 16.1, are all tests that must be performed on monolithic samples. ASTM C1285 (Product Consistency Test, PCT), ASTM 1662 (Single Pass Flow Through, SPFT), and the Pressure Unsaturated Flowthrough (PUF) test are all tests that must be performed on granular waste forms and/or monolithic waste forms that have been crushed to a small size so that the durability test response can be accelerated.

\section{C.1 ASTM C1220 (Monolith Immersion Test)}

"Summary: The ASTM C1220 test method [139] is based on the MCC-1 test method number 1. It is a static test in which a monolithic specimen of known geometric surface area is immersed in the appropriate volume of leachant to provide a specimen surface area-to-solution volume $(\mathrm{S} / \mathrm{V})$ ratio of $10 \mathrm{~m}^{-1}$. The test vessel is sealed and place in a constant-temperature oven for a prescribed duration. The solution concentrations of components of interest are measured at the end of the test. Tests can be conducted with demineralized water, synthetic or actual groundwaters, pH buffer solutions, etc. The test has been used to compare the relative reactivities of various waste form materials (usually in 28-day tests at $90^{\circ} \mathrm{C}$ ). Short-term tests at lower $S / V$ ratios can be used to measure specimen dissolution rates at high a chemical affinity and is convenient for measuring the effects of temperature and $\mathrm{pH}$. The surface finish of the specimen may affect the test response. For glass waste forms, a 600-grit finish provides the least polishing artifact and best represents the dissolution of bulk glass.

Advantages and Recommended Use: The test method is sensitive to the dissolution behavior of the waste form and the geometric surface area of a specimen can be measured to allow accurate calculation of the specific dissolution rate. The test is easy to run, can be conducted under a wide range of conditions, provides a large solution volume for analysis, and is economical. Only small volumes of waste solution are generated. Short-term tests can be used to measure the effects of temperature and $\mathrm{pH}$, and components in the leachant on the dissolution rate of materials that degrade by dissolution. Longer-term tests become affected by the affinity term and can be used to estimate the solubility of the waste form by regressing data with the rate expression.

Key uncertainties: The solution chemistry evolves over the test interval as the specimen dissolves and only the cumulative changes are measured. Initial dissolution 
is affected by artifacts from sample preparation (e.g., surface finish). The production of monolithic samples is usually the most difficult aspect of the test."

\section{C.2 ASTM C1285 (Product Consistency Test)}

"Summary: The ASTM C1285 test method [66] is based on the MCC test method number 3. It is a static test in which a specimen of crushed material is immersed in a volume of leachant at a known mass ratio. The mass and size fraction of the crushed material in the test is known and used to estimate the surface area. The test vessel is sealed and place in a constant-temperature oven for a prescribed duration. The solution concentrations of components of interest are measured at the end of the test. Tests is usually conducted with demineralized water, but can be conducted with synthetic or actual groundwaters. The ASTM C1285 method A (PCT-A) is conducted under specific test conditions:-100+200 mesh size fraction material; demineralized water; solid/solution mass ratio of $1 / 10 ; 90{ }^{\circ} \mathrm{C} ; 7$ days. ASTM C1285 method B (PCT-B) permits use of different test parameter values. Method B tests are useful for generating concentrated solutions to study chemical affinity effects on the dissolution rate. Method $B$ tests at high temperatures and high glass/solution mass ratios can be used to promote the formation of alteration phases to (1) identify the kinetically favored alteration phases (2) determine their propensity to sequester radionuclides, and (3) evaluate the effect of their formation on the continued waste form dissolution rate.

Advantages and Recommended Use: The test response is sensitive to solution feedback after very short test duration and drives the solution towards saturation. It is easy to run and economical. Only small volumes of waste solution are generated. The test method is best suited for studying dissolution in concentrated solutions and the effects of solution feed back; it is less sensitive to variations in the waste form composition.

Key uncertainties: The surface area of the crushed material must be estimated, the surface is affected by artifacts due to crushing (e.g., high-energy edges and points), the test results in very rapid changes in the solution composition at even short reaction times."

\section{C.3 ASTM C1308 (Accelerated Leach Test)}

"Summary: The ASTM C1308 accelerated leach test (ALT) [140] is a modification of the ANS/ANSI 16.1 test method that can be used to (1) determine if the release of a component is controlled by diffusion and (2) determine the effective diffusion coefficient based on a model for diffusion from a finite cylinder. It is a semi-dynamic test in which a monolithic specimen of prescribed dimensions is immersed in a large volume of leachant in a sealed vessel for a relatively short interval. The leachate 
solution is periodically removed for analysis and the sample is placed in fresh leachant to continue the test. The cumulative amounts of the species of interest released in successive test intervals are fitted with the diffusion equation for a finite cylinder. The test results can be used to qualitatively determine if the release of a component is controlled by diffusion alone, partitioned into a non-leachable fraction, or affected by solution saturation effects. Although evaluation of the diffusion coefficient requires use of a monolithic specimen having right cylinder geometry, the test method can be modified for use with crushed materials to determine (qualitatively) if releases are being controlled by diffusion.

Advantages and Recommended Use: Provides for the determination of an effective diffusion coefficient using a mechanistic model. The method provides a procedure to determine if release from small or irregular specimens is controlled by diffusion or matrix dissolution, even though the specimens cannot be modeled to determine a diffusion coefficient from the test data. Very large volumes of waste solution can result from testing.

Key uncertainties: Test results can be affected by retention of species of interest in non-leachable fractions (in the waste form or precipitation after release) and the effects of surface films on test specimens formed by casting."

\section{C.4 ASTM C1662 (Single-Pass Flow-Through Test)}

Summary: The ASTM C1662 test method [141] was based on single-pass flowthrough (SPFT) tests and is specifically developed to measure glass dissolution rates. It is a dynamic test in which leachant is flowed through a reaction cell containing crushed glass that is held at a constant temperature. The mass and size fraction of the crushed glass is known and used to estimate the surface area. The effluent solution is sampled periodically to measure the flow rate and concentrations of dissolved components. When steady-state concentrations are attained, the dissolution rate can be calculated from the steady-state concentration, flow rate, and material surface area. Tests with a range of flow rates and specimen surface areas can provide a measure of the dissolution rate when the chemical affinity is high. Tests conducted at various temperatures and with controlled leachant compositions can measure the effects of temperature and solution composition on the dissolution rate. NOTE: SPFT tests have been conducted at several laboratories for many years, but following different procedures that affected the test results. The ASTM C1662 test method was developed to provide a single procedure to allow direct comparison of the results from different laboratories.

Advantages and Recommended Use: The composition of the leachant solution can be controlled precisely and dissolution rates can be measured fairly precisely. The effects of the solution flow rate and sample surface area are taken into account when determining the dissolution rate using the rate equation for borosilicate glass dissolution. The test method should be appropriate for other materials that dissolve 
by the same mechanism, such as aluminosilicate minerals. The SPFT test is best suited for use with crushed materials, but tests can be conducted with monolithic specimens. Test method used to measure effects of various leachant components when waste solution volume not a limitation (e.g., with non-radioactive materials).

Key uncertainties: Uncertainty in the surface area of the crushed material, artifacts due to crushing (e.g., high-energy edges and points), and non-negligible decrease in sample surface area as the material dissolves in the test. The test is moderately complicated to conduct and several tests are needed for each set of conditions to take the effects of solution flow rate into account. Large volumes of waste solution are generated under most test conditions.

\section{C.5 ANL Drip Test}

Summary: The drip test method [142] was developed at ANL to simulate the effect of small amounts of transient water contacting waste in a breeched waste package. A small volume of groundwater is injected through a tube into the test vessel using a syringe and drips onto the specimen, which may be a monolith or crushed material in a sample cup suspended in the center of the vessel. Water flows around the specimen (or a small volume collects in the cup) and then drips to the bottom of the vessel. The test is interrupted periodically to collect and analyze the solution from the bottom of the vessel. The reacted solids can be analyzed at the end of the tests, or particles can be collected for analysis during the test. The drip test has not been standardized and is currently not conducted anywhere but ANL.

Advantages and Recommended Use: Wide range of leachant compositions and drip rates (on to specimen) and various materials interactions can be studied over long durations. The test is suitable for crushed or monolithic specimens, and altered specimen and alteration phases can be collected for analysis after testing. The test is suitable for confirmation testing of waste form corrosion mechanism in a hydrologically unsaturated environment.

Key Uncertainties: Uncontrolled solution flow paths, rates, and contacted surface area, lack of sampling solution contacting waste, and uncontrolled atmosphere.

\section{C.6 PNNL Pressurized Unsaturated Flow Test}

Summary: The pressurized unsaturated flow (PUF) test [143] was developed at PNNL to simulate the flow of water/air mixtures in a hydrologically unsaturated environment. The test method is similar to the single-pass flow-through test in that the water/air mixture flow through a crushed sample and the effluent is collected periodically for analysis. The leachant can be pre-conditioned by placing other materials upstream of the sample, for example to simulate interactions with geologic 
or engineering materials, and interactions of released species can be simulated by placing other materials down-stream of the sample. Reacted sample materials can be extracted and analyzed at the end of the test. The PUF test has not been standardized and is currently not conducted anywhere but PNNL.

Advantages and Recommended Use: The PUF test method can be used to directly incorporate materials interactions in the test and simulate integrated hydrologically unsaturated systems. Leachant composition is controlled and can be preconditioned prior to contacting the specimen and the solution chemistry resulting from corrosion can be tracked during test. Altered specimen and alteration phases can be collected for analysis after testing. Appropriate for confirmation testing of waste form corrosion mechanism in an integrated environment, regardless of whether it is hydrologically saturated or unsaturated. The method is not well-suited for tests with monolithic specimens because of uncertainties in the water flow path and contact with the specimen.

Key uncertainties: The surface area of crushed samples, preferential solution flow paths through sample, and possible modifications of the effluent prior to collection. The data resulting from several processes occurring in parallel or series can be difficult to relate to each specific process.

\section{C.7 Vapor Hydration Test (VHT)}

Summary: The vapor hydration test (VHT) [144] is a static test in which a monolithic specimen is suspended in a sealed vessel with a small amount of water. When heated, the vapor phase becomes saturated and a thin film of water condenses on the specimen. The amount of water in the vessel is carefully controlled so that no liquid water remains. This is done to prevent solution from dripping off the specimen and establishing a reflux cycle to maintain a static film of water on the specimen. Alteration phases formed on the reacted sample are analyzed and thickness of the altered surface layer is measured on a cross-sectioned specimen. An ASTM procedure for the $s$ vapor hydration test is being developed (draft WK84).

In a modification of the vapor hydration test, enough water is added to promote refluxing and the solution analyzed periodically to track the release of constituents. This provides very high $S / V$ ratios in a test with a monolithic specimen. This modification is similar to the Soxhlet test, except that the sample itself is used to condense the water vapor and maintain an adhering layer of water.

Advantages and Recommended Use: The VHT accelerates thermally activated materials alteration processes and the formation of alteration phases. This provides solids likely to form over long reaction times within a short test duration. The test is easy and economical to conduct and constrains alteration phases to form on the monolithic specimen to simplify collection for subsequent analysis. The modified VHT method serves as a simplified flow-through test or Soxhlet test at elevated 
WSRC-STI-2008-00268

Revision 0

temperatures. The VHT is recommended to accelerate the extent of corrosion to generate alteration phases for analysis, and to determine the effect of phase formation on the continued corrosion of the material.

Key uncertainties: Neither the actual acceleration factor nor the chemistry and volume of the solution contacting the specimen during reaction are known. The test response is sensitive to the volume of water that condenses on the specimen, which cannot be controlled accurately or measured during the test. The extent of corrosion can be estimated based on the amounts of alteration phases that formed, but the precision of the test is poor and the VHT is poorly suited for quantifying corrosion rates.” 


\section{APPENDIX D-DURABILITY TESTING: SURFACE AREA MEASUREMENT AND CHOICE OF BUFFERED LEACHANTS}

\section{D.1 Reporting Units and Test Acceleration}

It should be noted that in the PCT test (Section C.2 ), the SPFT test (Section C4), and the PUF test (Section C6) that the key uncertainty in the testing protocol is the estimation of the surface area of the crushed waste form. The surface area becomes important because during the calculation of the normalized dissolution "release" or "rate" a term in the denominator of Equation 6 through Equation 8 relies on the "surface area of the waste form exposed to the solution." The results of the PCT can be expressed in different units, e.g. $\mathrm{NC}_{\mathrm{i}}(\mathrm{g} / \mathrm{L}), \mathrm{NL}_{\mathrm{i}}$ $\left(\mathrm{g} / \mathrm{m}^{2}\right)$, or $\mathrm{NR}_{\mathrm{i}}\left(\mathrm{g} / \mathrm{m}^{2} \bullet\right.$ day) where " $\mathrm{i}$ " is the element of interest in the waste form. If durability results are compared for the same waste form of a consistent density and are always prepared in the same manner, then the units of $\mathrm{NC}_{\mathrm{i}}$ (Equation 5) can be used and no surface area estimation need be made. This assumes that the surface areas are always similar and not highly variable. Both the $\mathrm{NL}_{\mathrm{i}}\left(\mathrm{g} / \mathrm{m}^{2}\right)$ and the $\mathrm{NR}_{\mathrm{i}}\left(\mathrm{g} / \mathrm{m}^{2} \bullet\right.$ day) require a surface area term as does the $\mathrm{NR}_{\mathrm{i}}\left(\mathrm{g} / \mathrm{m}^{2} \bullet\right.$ day) determined from the SPFT test.

In the PCT procedure (ASTM C1285) calculating the concentration in normalized mass units $\mathrm{NC}_{\mathrm{i}}$ or $\log \left[\mathrm{NC}_{\mathrm{i}}\right]$ is recommended for all waste forms, including glasses and multiphase glass ceramic waste forms, because the release concentrations in $\mathrm{g} / \mathrm{L}$ are normalized by the weight fraction of that element present in the waste form. The normalized release, $\mathrm{NC}_{\mathrm{i}}$, is a function of (1) the mass fraction of the $i^{\text {th }}$ element of interest in the waste form and (2) the concentration of the $i^{\text {th }}$ species in solution. ${ }^{\dagger}$ The normalized concentration for each replicate is expressed as:

Equation 5

$$
N C_{i}=\frac{c_{i}(\text { sample })}{f_{i}}
$$

where $\quad \mathrm{NC}_{\mathrm{i}}=$ normalized concentration $\left(\mathrm{g}_{\text {waste }}\right.$ form $/$ Lleachant $)$

$c_{i}($ sample $)=$ concentration of element "i" in the solution $(\mathrm{gi} / \mathrm{L})$

$\mathrm{f}_{\mathrm{i}}=$ fraction of element "i" in the unleached waste form (unitless)

The units of $\mathrm{NC}_{\mathrm{i}}$ for PCT-A are normally expressed as grams of waste form dissolved per liter of leachant when all of the tests are performed at the reference volume of leachant $\left(\mathrm{V}_{\text {soln }}\right)$ to sample mass $\left(\mathrm{m}_{\text {solid }}\right)$, e.g. $\mathrm{V}_{\text {soln }} / \mathrm{m}_{\text {solid }}=10 \pm 0.5 \mathrm{~cm}^{3} / \mathrm{g}$, and at the $100-200$ mesh reference particle size (see Appendix X1 of the ASTM procedure). Use of the reference conditions maintains the waste form surface area (A) to volume of leachant (V) at a constant. As long as the waste form density and waste form particle size remain comparable between leach tests, this parameter will remain approximately constant and need not be calculated every time.

At the dilute solute concentrations utilized in this report, a $\mathrm{kg}$ of solution is considered equivalent to 1 liter of solution and so $\mathrm{ppm}$ and $\mathrm{mg} / \mathrm{L}$ can be used interchangeably. 
Alternatively, a normalized release rate, $\mathrm{NR}_{\mathrm{i}}$ expressed as grams of waste form dissolved per $\mathrm{m}^{2} \bullet$ day, can be calculated based on the PCT (ASTM C1285) results when the particle size, $\mathrm{V}_{\text {soln }} / \mathrm{m}_{\text {solid, }}$, and time are varied between tests, or for test results on waste forms of different density. The following expression may be used to calculate $\mathrm{NR}_{\mathrm{i}}$ :

Equation 6

$$
N R_{i}=\frac{c_{i}(\text { sample })}{\left(f_{i}\right) \bullet(S A / V) \bullet(t)}
$$

where $\quad \mathrm{NR}_{\mathrm{i}}=$ normalized rate $\left(\mathrm{g}_{\text {waste }}\right.$ form $/ \mathrm{m}^{2} \bullet$ day)

$c_{i}($ sample $)=$ concentration of element "i" in the solution $(\mathrm{gi} / \mathrm{L})$

$\mathrm{f}_{\mathrm{i}}=$ fraction of element " $\mathrm{i}$ " in the unleached waste form (unitless)

$\mathrm{SA} / \mathrm{V}=$ surface area of final waste form divided by the leachate volume

$\left(\mathrm{m}^{2} / \mathrm{L}\right)$

$$
\mathrm{t}=\text { time duration of test in days }
$$

If the units of time are omitted from the $\mathrm{NR}_{\mathrm{i}}$ calculation, then the normalized release, $\mathrm{NL}_{\mathrm{i}}$, is calculated as

Equation 7

$$
N L_{i}=\frac{c_{i}(\text { sample })}{\left(f_{i}\right) \bullet(S A / V)}
$$

where

$$
\mathrm{NL}_{\mathrm{i}}=\text { normalized release }\left(\mathrm{g}_{\mathrm{waste}} \text { form } / \mathrm{m}^{2}\right)
$$

$c_{i}($ sample $)=$ concentration of element "i" in the solution $\left(\mathrm{gi}_{\mathrm{i}} / \mathrm{L}\right)$

$\mathrm{f}_{\mathrm{i}}=$ fraction of element " $\mathrm{i}$ " in the unleached waste form (unitless)

$\mathrm{SA} / \mathrm{V}=$ surface area of final waste form divided by the leachate volume $\left(\mathrm{m}^{2} / \mathrm{L}\right)$

The results of the SPFT testing are also normally expressed in units of $\mathrm{NR}_{\mathrm{i}}$ expressed as grams of waste form dissolved per $\mathrm{m}^{2} \bullet$ day as follows:

Equation 8

$$
N R_{i}=\frac{c_{i}(\text { steadystateconcentrationof i fromsample }) \bullet(F)}{\left(f_{i}\right) \bullet(S)}
$$

where $\quad \mathrm{NR}_{\mathbf{i}}=$ normalized rate $\left(\mathrm{g}_{\text {waste }}\right.$ form $/ \mathrm{m}^{2} \bullet$ day $)$

$c_{i}($ sample $)=$ concentration of element "i" in the solution $(\mathrm{gi} / \mathrm{L})$

$\mathrm{f}_{\mathrm{i}}=$ fraction of element " $\mathrm{i}$ " in the unleached waste form (unitless)

$\mathrm{S}=$ surface area of the waste form exposed to the leachant

$\mathrm{F}=$ flow through rate (L/day) 
For glass waste forms the responses of a variety of these laboratory durability tests have been related to each other. For example:

- Short-term crushed glass tests (ASTM C-1285, PCT, MCC-3) have been related to long-term crushed glass tests (ASTM C-1285, PCT, MCC-3) $[145,146,147,148]$.

- Short- and long-term monolith tests (ASTM C-1220, MCC-1) have been related to short- and long-term crushed glass tests (ASTM C-1285, PCT, MCC-3) [147, $148149]$.

- Short- and long-term monolith tests have been related to long-term burial tests $[150,151,152]$.

- The responses of long-term crushed glass tests (ASTM C-1285, PCT) have been related to shorter term, higher temperature, VHT responses, e.g. the HLW Environmental Assessment (EA) glass reaches the same stage of durability within 56 days at $20,000 \mathrm{~m}^{-1}$ or $>313$ days at $2000 \mathrm{~m}^{-1}$ when tested by PCT at $90^{\circ} \mathrm{C}$ [149] or within 6 days when tested by VHT at $200^{\circ} \mathrm{C}$ [149].

- The forward rate of a short-term monolith test (ASTM C-1220, MCC-1) has been shown to be equivalent to the forward rate of the single pass flow though (SPFT) test $[86,149]$.

The relation of the different test responses demonstrates that the test responses are related, although they are monitoring different aspects of the leaching mechanisms. When performing these comparisons care must be taken [153] during test data interpretation, since different $\mathrm{pH}$ values are achieved during static testing at different $\mathrm{SA} / \mathrm{V}$ ratios and this may affect the reaction rate and the phases that form and must be accounted for when comparing the results of tests. In most glass studies, the PCT is used to determine the maximum rate of radionuclide release if the leaching is congruent and the SPFT test is used to monitor the rate of matrix degradation.

McGrail [154] has stated that the geometric methodology of the determination of surface area given in the PCT test protocol (ASTM C1285) is the correct way to assess the surface area of vitreous waste forms and he has stated that the BET surface area is the correct way to assess the surface area of FBSR products in SPFT and PUF tests [98] in order to account for the additional surface roughness in the FBSR product (Figure 26a) vs. glass (Figure 26b). The measured, BET method more accurately determines the surface area of FBSR product due to the more porous and irregular surface of the material (Figure 26a). The surface of a glass is much more regular (Figure 26b) and the calculated geometric surface area is typically used for determining dissolution behavior.

However, a variety of surface area methodologies have been used by different investigators for waste forms that are not glass: 
- Geometric surface area (recommended by PCT procedure [66] and used for glass, glass ceramics including glass bonded sodalite, and devitrified glass for PCT and SPFT)

- $\quad$ used by Jantzen in early PCT testing of FBSR product [94]

- Brunauer-Emmett-Teller (BET) nitrogen surface area [155]

- $\quad$ used by McGrail for FBSR, SPFT, and PUF testing of FBSR product [98,99]

- $\quad$ used by Jantzen/Pareizs in PCT testing of FBSR product [95,96,97]

- $\quad$ used by Jantzen/Lorier in SPFT testing of FBSR product [97,99,101]

- $\quad$ used by Zhao et.al. of Lawrence Livermore National Laboratory (LLNL) for SPFT testing of Pu Ceramics [156]

- used by French researchers for Soxhlet testing of Pu ceramics [157]

- $\quad$ used by Icenhower, et. al for Pu ceramics [158]

- $\quad$ Pore size measurement and calculation of surface area

- used by McGrail for Bulk Vitrification Foam Glass [99]

Thus the consensus has been to use geometric surface area for smooth surface waste forms (glasses and glass ceramics) and BET surface area for ceramic and mineral waste forms to account for surface roughness. Note that the surface roughness factor $\mathrm{SA}_{\mathrm{BET}} / \mathrm{SA}_{\text {geometric }}$ has been found to vary from 100-370 for FBSR $[94,96]$ and ceramic waste forms. If the leach rates of the FBSR product are expressed without the SA term (Equation 5) then glass and FBSR product have similar durabilities [94]. If the leach rates of the FBSR product are expressed with a SA term (Equation 6 or Equation 7 or Equation 8), then the FBSR product is two orders of magnitude more durable than glass [94,96,97].

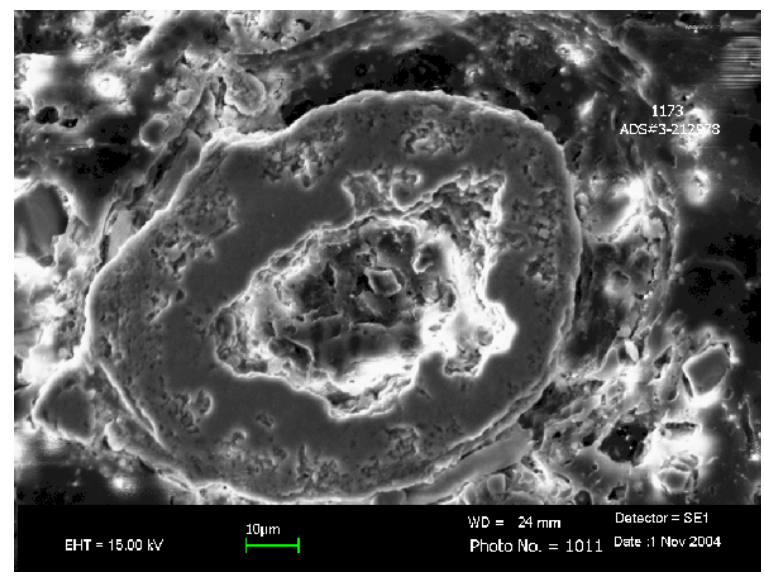

(a)

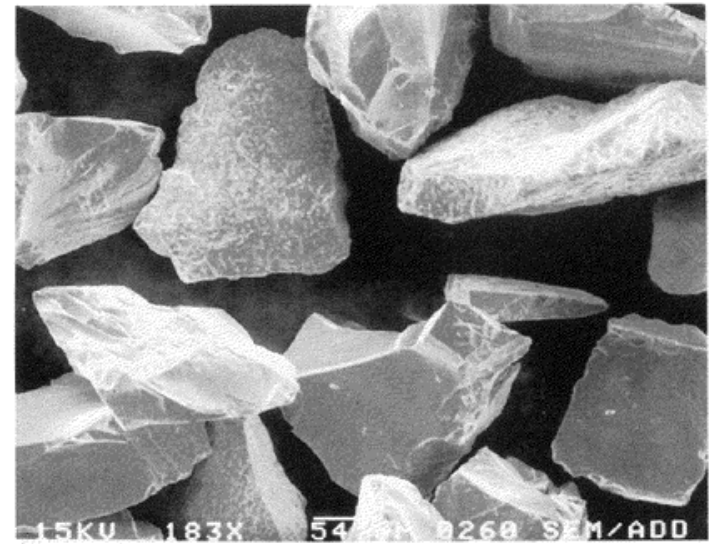

(b)

Figure 26. Rough surface of an FBSR waste form (left) and smooth surface of vitrous waste form (right). 


\section{D.2 Durability Test Protocols: Impact of Leachants}

\section{D.2.1 Product Consistency Test (ASTM C1285)}

The following text is from ASTM C1285:

The product consistency test methods A and B evaluate the chemical durability of homogeneous glasses, phase separated glasses, devitrified glasses, glass ceramics, and/or multiphase glass ceramic waste forms hereafter collectively referred to as "glassy waste forms" by measuring the concentrations of the chemical species released to a test solution. Test Method A is a seven-day chemical durability test performed at $90 \pm 2{ }^{\circ} \mathrm{C}$ in a leachant of ASTM-Type I water. Test Method A can specifically be used to evaluate whether the chemical durability and elemental release characteristics of nuclear, hazardous, and mixed glass waste forms have been consistently controlled during production. Test Method B can specifically be used to measure the chemical durability of glassy waste forms under various leaching conditions, for example, varying test durations, test temperatures, ratio of sample surface area (S) to leachant volume (V), and leachant types. Data from Test Method B may form part of the larger body of data that are necessary in the logical approach to long-term prediction of waste form behavior (see Practice C 1174).

The PCT-A procedure must be performed in ASTM Type I (deionized) water. The PCT-B procedure may be performed in any leachant including ASTM Type I water, simulated groundwaters, actual groundwaters or other leachants.

\section{D.2.2 Single Pass Flow Through (ASTM 1662)}

The following text is from ASTM C1662:

The SPFT test is used to measure the dissolution rate of a homogeneous silicate glass, including nuclear waste glasses, in various test solutions at temperatures less than $100^{\circ} \mathrm{C}$. Tests may be conducted under conditions in which the effects from dissolved species on the dissolution rate are minimized to measure the forward dissolution rate at specific values of temperature and $\mathrm{pH}$, or to measure the dependence of the dissolution rate on the concentrations of various solute species. Tests are conducted by pumping solutions in either a continuous or pulsed flow mode through a reaction cell that contains the test specimen. Tests must be conducted at several solution flow rates to evaluate the effect of the flow rate on the glass dissolution rate. Tests may be conducted with demineralized water, $\mathrm{pH}$ buffer solutions, simulated groundwater solutions or actual groundwaters. Data from these tests can be used to determine the values of kinetic model parameters needed to calculate the glass corrosion behavior in a disposal system over long periods of time (see ASTM C1174). It should also be noted that the SPFT test originated for the geologic study of the degradation of single phase minerals in nature [104,105159] and is now being applied to glass waste forms.

The intrinsic rate constant can be calculated using the forward glass dissolution rates measured at various temperatures and $\mathrm{pH}$ values in a mechanistic rate expression such as: 


$$
\begin{aligned}
& \text { Equation } 9 \quad \text { rate }=k_{0} \bullet 10^{\eta p H} \bullet \exp \left(\frac{-E_{a}}{R T}\right) \bullet\left(1-\frac{Q}{K}\right) \\
& \text { where } \mathrm{k}_{0}=\text { intrinsic rate constant } \\
& \eta=\text { the } \mathrm{pH} \text { dependence } \\
& \mathrm{E}_{\mathrm{a}}=\text { the activation energy } \\
& \mathrm{R}=\text { gas constant } \\
& \mathrm{T}=\text { absolute temperature } \\
& \mathrm{Q} / \mathrm{K}=\text { saturation index }
\end{aligned}
$$

The values of $\eta$ and $\mathrm{Ea}$ are determined by regressing data in a plot of log rate versus $\mathrm{pH}$ at the various temperatures, if it is assumed that $\eta$ is independent of temperature and the value of $\mathrm{Ea}$ is independent of $\mathrm{pH}$.

The waste form surface area in ASTM 1662 is recommended to be the geometric surface area for glass waste forms. If a crushed sample is used instead of a monolithic sample, the sample is prepared in the same manner as for PCT analysis, e.g. washed of adhering fines and sieved to -100 and +200 mesh. The recommended elements to be monitored are boron and silicon rather than alkali metals, as the release rate desired is that of the matrix dissolution and not ion exchange.

In order to develop the data needed for Equation 9 one must perform dissolutions at a variety of flow rates, several different constant $\mathrm{pH}$ values, and several different temperatures. The constant $\mathrm{pH}$ values are achieved by performing the dissolution (glass or mineral) in a variety of $\mathrm{pH}$ buffer solutions. The procedure cautions that "buffers should be selected to avoid strong complexants and solutes known to affect the dissolution rate." The buffer solutions recommended in ASTM C1662 are given in Table VI as well as those recently used for SPFT of FBSR product. It should be noted that the buffers used for the SPFT of the FBSR product include oxidizers such as nitric acid, which may have altered the dissolution rate of the FBSR products produced under reducing conditions. 
Table VI. Composition of pH Buffers Used in Various SPFT Tests

\begin{tabular}{|c|c|}
\hline \multicolumn{2}{|c|}{ ASTM C1662 + McGrail for Na-Ca-Al-B-Si LAW Glass [154] } \\
\hline Buffer Composition & $\mathrm{pH}$ at $90^{\circ} \mathrm{C}$ \\
\hline $0.005 \mathrm{~m}$ Potassium hydrogen phthalate $+0.004 \mathrm{~m} \mathrm{LiOH}$ & 5.89 \\
\hline $0.005 \mathrm{~m} \mathrm{H}_{3} \mathrm{BO}_{3}+0.0003 \mathrm{~m} \mathrm{LiOH}$ & 7.62 \\
\hline $0.005 \mathrm{~m} \mathrm{H}_{3} \mathrm{BO}_{3}+0.0020 \mathrm{~m} \mathrm{LiOH}$ & 8.59 \\
\hline $0.005 \mathrm{~m} \mathrm{H}_{3} \mathrm{BO}_{3}+0.0044 \mathrm{~m} \mathrm{LiOH}$ & 9.25 \\
\hline $0.004 \mathrm{~m} \mathrm{LiCl}+0.001 \mathrm{~m} \mathrm{LiOH}$ & 9.39 \\
\hline $0.005 \mathrm{~m} \mathrm{LiCl}+0.0107 \mathrm{~m} \mathrm{LiOH}$ & 10.39 \\
\hline \multicolumn{2}{|c|}{ FBSR Leaching by McGrail [98] \& Lorier [97,99,101] } \\
\hline $0.01 \mathrm{~m}$ TRIS $*+0.0093 \mathrm{HNO}_{3}$ & 5.50 \\
\hline $0.01 \mathrm{~m}$ TRIS $*+0.0059 \mathrm{HNO}_{3}$ & 6.52 \\
\hline $0.05 \mathrm{~m}$ TRIS $*+0.0079 \mathrm{HNO}_{3}$ & 7.42 \\
\hline $0.05 \mathrm{~m}$ TRIS* & 8.52 \\
\hline $0.01 \mathrm{~m} \mathrm{LiCl}+0.0107 \mathrm{LiOH}$ & 10.12 \\
\hline
\end{tabular}

$*$ TRIS $=$ tris (hydroxymethyl) aminomethane 
WSRC-STI-2008-00268

Revision 0

\section{APPENDIX E-ALL REFERENCES}

1. C.A. Mawson, Management of Radioactive Wastes, D. VanNostrand Co., Inc., New Jersey, 196 pp (1965).

2. R. Bonniaud and P. Rancon, "Vitrification Des Solutions Concentrees De Produits de Fission: Etudes Technologiques,” Treatment and Storage of High Level Radioactive Wastes, International Atomic Energy Agency, Vienna, 507-529 (1963).

3. W. Lutze and R.C. Ewing, "Radioactive Waste Forms for the Future,” Elsevier Science Publishers, Amsterdam, The Netherlands, 778pp (1988).

4. P.E.D. Morgan, D.R. Clarke, C.M. Jantzen and A.B. Harker, "High-Alumina Tailored Nuclear Waste Ceramics” J. Am. Ceram. Soc. 64[5] 249-58 (1981).

5. C.M. Jantzen, D.R. Clarke, P.E.D. Morgan and A.B. Harker, "Leaching of Polyphase Nuclear Waste Ceramics: Microstructural and Phase Characterization,” J. Am. Ceram. Soc. 65[6], 292-300 (1982).

6. L.P. Hatch, “Ultimate Disposal of Radioactive Wastes,” Am. Scientist, 41, 410-421 (1953).

7. G.S. Barney, "Fixation of Radioactive Waste by Hydrothermal Reaction with Clays,” Chapter 8 in High Level Radwaste Management, M.H. Campbell, JACS (1976).

8. D.M. Strachan, and W.W. Schulz, “Characterization of Pollucite as a Material for Long-Term Storage of Cesium-137,” Am. Ceram. Soc. Bull., V58 [9], 865-871 (1979).

9. C.H. Delegard and G.S. Barney, "Fixation of Radioactive Waste by Reaction with Clays: Progress Report,” U.S. DOE Report ARH-ST-124 (July 1975).

10. L.E. Brown, C.H. Kindle, and T.L. Theis, "Review of Literature Pertinent to the Aqueous Converstion of Radionuclides to Insoluble Silicates with Selected References and Bibliography (Revised),' U.S. DOE Report ARH-2731, Rev. 1 (December, 1973).

11. G.S. Barney, "Fixation of Radioactive Waste by Hydrothermal Reactions with Clays,” Chapter 8 in High-Level Radioactive Waste Management, M.H. Campbell (Ed.), Advances in Chemistry Series 153, American Chemical Society, Washington, DC, pp.108-125 (1976). 
12. R. Roy, "Hydroxylated Ceramic Waste Forms and the Absurdity of Leach Tests,” Proc. Int. Sem. On Chemistry and Process Engineering for High-Level Liquid Waste Solidification, Vol. 2, Julich, JUL-Conf-42, eds. R. Odoj and E. Merz, 576-602 (1981).

13. R. Hesbol and J. B. Mason, “ Method for the Volume Reduction and Processing of Nuclear Waste,” U.S. Patent \#5,909,654 (June 1999).

14. J.B. Mason, T.W. Oliver, M.P. Carson, and G.M. Hill, “Studsvik Processing Facility Pyrolysis/Steam Reforming Technology for Volume and Weight Reduction and Stabilization of LLRW and Mixed Wastes," Waste Management $\underline{99}$ (1999).

15. B.C. Bunker, G.W. Arnold, D.E. Day and P.J. Bray, "The Effect of Molecular

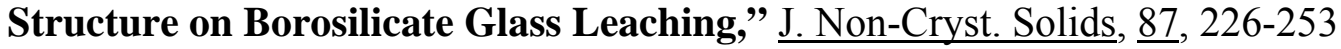
(1986).

16. G.E. Brown, Jr., F. Farges, and G. Calas, “X-Ray Scattering and X-Ray Spectroscopy Studies of Silicate Melts," Structure, Dynamics and Properties of Silicate Melts, J.F. Stebbins, P.F. McMillan, and D.B. Dingwell (Eds.), Reviews in Mineralogy, V.32, 317-410 (1995).

17. C.W. Burnham, “The Nature of Multicomponent Aluminosilicate Melts,” Phys. Chem. of the Earth, v13 \& 14, 191-227 (1981).

18. W.B. White, “Glass Structure and Glass Durability," Materials Stability and Environmental Degradation, A. Barkatt, E.D. Vernik, and L.R. Smith (Eds.), MRS Symposium Proceedings V. 125 (1988).

19. A.J.G. Ellison and A. Navrotsky, "Thermochemistry and Structure of Model Waste Glass Compositions," Sci. Basis for Nuclear Waste Management, XIII, V.M. Oversby and P.W. Brown (Eds.) Materials Research Society, Pittsburgh, PA, 193-207 (1990).

20. H. Li, Y. Su, J.D. Vienna, and P. Hrma, "Raman Spectroscopic Study - Effects of $\mathrm{B}_{2} \mathrm{O}_{3}, \mathrm{Na}_{2} \mathrm{O}$, and $\mathrm{SiO}_{2}$ on Nepheline ( $\left.\mathrm{NaAlSiO}_{4}\right)$ Crystallization in Simulated High Level Waste Glasses,” Environmental Issues and Waste Management Technologies, V, G.T. Chandler and X. Feng (Eds.), Ceramic Trans. 107, 469-477 (2000).

21. G.N. Greaves, “EXAFS, Glass Structure and DIffusion,” Phil. Mag. B, 60[6] 793800 (1989).

22. T.M. El-Shamy, “The Chemical Durability of $\mathrm{K}_{2} \mathrm{O}-\mathrm{CaO}-\mathrm{MgO}-\mathrm{SiO}_{2}$ Glasses,” Phys. Chem. Glasses, 14[1], 1-5 (1973). 
23. P.C. Hess, “Polymerization Model for Silicate Melts,” In. Physics of Magmatic Processes, K.B. Hargraves (Ed.), Princeton University Press, 1-48 (1980).

24. Y. Bottinga and P. Richet, “Thermodynamics of Liquid Silicates, A Preliminary Report,”Earth Plan. Sci. Lett, 40, 382-400 (1978).

25. C.S. Marians and L.E. Hobbs, “Network properties of Crystalline Polymorphs of Silica,” J. Non-Crystalline Solids, 124, 242-253 (1990).

26. National Academy of Sciences, “Dictionary of Geological Terms,” Dolphin Books, Doubleday \& Co., Inc., Garden City, NY, 545pp, 5721pp (1962, 1984).

27. F. Liebau, “Structure and Bonding in Crystals, II,” Academic Press, NY, 197pp (1981).

28. R. Roy, “Rational Molecular Engineering of Ceramic Materials,” J. Am. Ceram. Soc. 60, 350-363 (1977).

29. G.J. McCarthy, "Radioactive Waste Management: The Nuclear Waste Form,” Earth and Mineral Sciences, 45, 17-20 (1975).

30. W.L. Bourcier, “Affinity Functions for Modeling Glass Dissolution Rates,” U.S. DOE Report UCRL-JC-131186 (1998) prepared for the Atomic Energy

Commisssion, Vallee due Rhone Summer Workshop: Glass: Scientific Research for High Performance Containment in Jejannes-le-Clap, France.

31. J.P. Hamilton, S.L. Brantley, C.G. Pantano, L.J. Criscenti, and J.D. Kubicki, "Dissolution of Nepheline, Jadeite, and Albite Glasses: Toward Better Models for Aluminosilicate Dissolution,” Geochemica et Cosmochimica Acta, 65 [21], 3683-3702 (2001).

32. N. Tsomaia, S.L. Brantley, J.P. Hamilton, C.G. Pantano, and K.T. Mueller, "Solid State NMR Studies of Aluminate and Silicate Environments in Surface Layers of Leached Aluminosilicate Glasses and Crystals: Implications for Dissolution,” American Mineralogist, 88, 54-67 (2003).

33. W. Vogel, “Chemistry of Glass,” Am. Ceram. Soc., Columbus, OH, pp.111-113 (1985).

34. C.M. Jantzen, "Engineering Study of the Hanford Low Activity Waste (LAW) Steam Reforming Process,” U.S. DOE Report WSRC-TR-2002-00317, Westinghouse Savannah River Co., Aiken, SC (July, 2002). 
35. G.J. McCarthy and M.T. Davidson, “Ceramic Nuclear Waste Forms:I.,”Am. Ceram. Soc. Bull., 54, 782-786 (1975) and "Ceramic Nuclear Waste Forms:II," Am. Ceram. Soc. Am. Ceram. Soc. Bull., 55[2]190-194(1976).

36. D.G. Brookins, “Geochemical Aspects of Radioactive Waste Disposal,” SpringerVerlag, New York, 347pp. (1984).

37. R.M. Barrer, “Hydrothermal Chemistry of Zeolites,” Academic Press, New York, 360pp (1982): see references by St. J. Thugutt, Z. Anorg. Chem, 2, 65 (1892) and E. Flint, W. Clarke, E.S. Newman, L. Shartsis, D. Bishop and L.S. Wells, J. Res. Natl. Bur. Stds, 36, 63 (1945).

38. D.M. Tobbens and J.C. Buhl, “Superstructure of Sodiumborate Sodalite,” Berline Neutron Scattering Center (BENSC) Experimental Report E9, Helmholtz Zentrum fur Materialiene und Energie (formally the Hahn-Meitner Institute), Berlin, Germany (2000).

39. S.V. Mattigod, B.P. McGrail, D.E. McCready, L.Wang, K.E. Parker and J.S. Young, "Synthesis and Structure of Perrhenate Sodalite," J. Microporous \& Mesopourous Materials, 91 (1-3), 139-144 (2006).

40. W. Sinkler, T.P. O’Holleran, S.M. Frank, M.K. Richmann, S.G. Johnson, “Characterization of A Glass-Bonded Ceramic Waste Form Loaded with $U$ and Pu,” Scientific Basis for Nuclear Waste Management, XXIII, R.W. Smith and D.W. Shoesmith (Eds.), Materials Research Society, Pittsburgh, PA, 423-429 (2000).

41. T. Moschetti, W. Sinkler, T. Disanto, M.H. Hois, A.R. Warren, D. Cummings, S.G. Johnson, K.M. Goff, K.J. Bateman, S.M. Frank, "Characterization of a Ceramic Waste Form Encapsulating Radioactive Electrorefiner Salt,” Scientific Basis for Nuclear Waste Management, XXIII, R.W. Smith and D.W. Shoesmith (Eds.), Materials Research Society, Pittsburgh, PA, 577-582 (2000).

42 L.R. Morss, M.L. Stanley, C.D. Tatko, W.L. Ebert, “Corrosion of Glass Bonded Sodalite as a Function of $\mathbf{p H}$ and Temperature," Scientific Basis for Nuclear Waste Management, XXIII, R.W. Smith and D.W. Shoesmith (Eds.), Materials Research Society, Pittsburgh, PA, 733-738 (2000).

43. J.K. Bates and L.J. Jardine, “Hydration Aging of Nuclear Waste Glass,” Science, 218, 51-52 (1982).

44. F. C. Perez-Cardenas, Hao Gan, Xiaodong Lu, and I.L. Pegg, "Mechanism of Vapor Phase Hydration in High Sodium Waste Glasses from Computer Simulations," Scientific Basis for Nuclear Waste Mgt. XXV, B.P. McGrail and G.A. Cragnoliono (Eds.), Materials Research Society, Pittsburgh, PA., 581-588 (2002). 
45. Kirk-Othmer Encyclopedia of Chemistry, “Molecular Sieves,” Vol. 16 (1995).

46. R. M. Barrer, J. W. Baynham, F. W. Bultitude, and W. M. Meier, "Hydrothermal Chemistry of the Silicates. Part VIII., Low-Temperature Crystal Growth of Aluminosilicates, and of Some Gallium and Germanium Analogues,” J. Chem Soc., 195-208 (1959).

47. R. M. Milton, U.S. Patents \#2,882,243 and \#2,882,244 (1959)

48. R.M. Barrer, J.F. Cole, and H. Sticher, "Chemistry of Soil Minerals. Part V. Low Temperature Hydrothermal Transformations of Kaolinite,” Jour. Chem. Soc., 2475-2485 (1968).

49. W.A. Deer, R.A. Howie, W.S. Wise, and J. Zussman, "Rock-Forming Minerals, Vol. 4B, Framework Silicates: Silica Minerals, Feldspathoids and the Zeolites," The Geological Society, London, UK, 982pp (2004).

50. W. A. Deer, R. A. Howie, and J. Zussman, “Rock-Forming Minerals, Vol IV, Framework Silicates” John Wiley \& Sons, Inc., New York, 435pp. (1963).

51. J.Ch. Buhl, G. Englehardt, and J. Felsche, “Synthesis, X-ray Diffraction, and MAS n.m.r. Characteristics of Tetrahydroxoborate Sodalite,” Zeolites, 9, 40-44 (1989).

52. M.E. Fleet, “Structures of Sodium Alumino-Germanate Sodalites,” Acta Cryst., C45, 843-847 (1989).

53. R.E. Grim, Clay Mineralogy, Science, 135, \#3507, 890-898 (1962).

54. R.E. Grim, Clay Mineraology, McGraw Hill Book Company, Inc., 384 (1953).

55. Kirk-Othmer Encyclopedia of Chemistry, Vol. 16 (1995).

56. R. M. Barrer, J. W. Baynham, F. W. Bultitude, and W. M. Meier, "Hydrothermal Chemistry of the Silicates. Part V23I, Low-Temperature Crystal Growth of Aluminosilicates, and of Some Gallium and Germanium Analogues,” 195-208 (1959).

57. E.S. Dana, “A Textbook of Mineralogy,” John Wiley \& Sons, Inc., New York, $851 \mathrm{pp}(1932)$.

58. I. Hassan and H.D. Grundy, “ The Crystal Structures of Sodalite-Group Minerals,” Acta Cryst. B40, 6-13 (1984). 
59. R. Klingenberg and J. Felsche, "Interstitial Cristobalite-type Compounds $\left.\left(\mathrm{Na}_{2} \mathbf{O}\right)_{0.33} \mathrm{Na}\left[\mathrm{AlSiO}_{4}\right]\right)$,” J. Solid State Chemistry, 61, 40-46 (1986).

60. W. A. Deer, R. A. Howie, and J. Zussman, "Rock-Forming Minerals, Vol V, NonSilicates,” John Wiley \& Sons, Inc., New York, 371pp. (1962).

61. G.D. Gatta, N. Rotiroti, P.F. Zanazzi, M. Rieder, M. Drabek, Z. Weiss, and R. Klaska, "Synthesis and Crystal Structure of the Feldspathoid CsAlSiO4: An Open-Framework Silicate and Potential Nuclear Waste Disposal Phase," American Mineralogist, V. 93, 988-995 (2008).

62. P. Vulic, V. Kahlenberg, and J. Konzett, “On the Exitence of a Na-deficient Monoclinic trinepheline with Composition $\mathrm{Na}_{7.85} \mathrm{Al}_{7.85} \mathrm{Si}_{8.15} \mathrm{O}_{32}$," American Mineralogist, 03, 1072-1079 (2008).

63. G. Calas, M. LeGrand, L. Galoisy, and D. Ghaleb, "Structural Role of Molybdenum in Nuclear Waste Glasses: an EXAFS Study,” J. Nuclear Mat. v. 322 [1], 15-20 (2003).

64. H.D. Schreiber, "Redox State of Model Fluidized Bed Steam Reforming Systems Final Report Subcontract AC59529T," VMI Research Laboratories, VMI, Lexington, VA 24450 (December 2007).

65. W.B. White, "Theory of Corrosion of Glass and Ceramics," Corrosion of Glass, Ceramics, and Ceramic Superconductors, D.E. Clark and B.K. Zoitos, Noyes Publications, Park Ridge, NJ, 2-28 (1992).

66. Standard Test Methods for Determining Chemical Durability of Nuclear Waste Glasses: The Product Consistency Test (PCT) Standard C1285, Annual Book ofASTM Standards Vol. 12.01, American Society for Testing and Materials, West Conshohocken, PA (2008).

67. N.E. Bibler and J.K. Bates, "Product Consistency Leach Tests of Savannah River Site Radioactive Waste Glasses,” Scientific Basis for Nuclear Waste Management, XIII, Oversby, V. M. and Brown, P. W., eds., Materials Research Society, Pittsburgh, PA, 1990, pp. 327-338.

68. J.K. Bates, D.J. Lam, M.J. Steindler, "Extended Leach Studies of Actinide-Doped SRL 131 Glass,” Scientific Basis for Nuclear Waste Management, VI, D.G. Brookins (Ed.), North-Holland, New York, 183-190 (1983).

69. N.E. Bibler and A.R. Jurgensen, "Leaching Tc-99 from SRP Glass in Simulated Tuff and Salt Groundwaters,” Scientific Basis for Nuclear Waste Management, XI, M.J. Apted and R.E. Westerman (Eds.), Materials Research Society, Pittsburgh, PA, 585-593 (1988). 
70. D.J. Bradley, C.O. Harvey, and R.P. Turcotte, "Leaching of Actinides and Technetium from Simulated High-Level Waste Glass,” Pacific Northwest Laboratory Report, PNL-3152, Richland, WA (1979).

71. S. Fillet, J. Nogues, E. Vernaz, and N. Jacquet-Francillon, “Leaching of Actinides from the French LWR Reference Glass,” Scientific Basis for Nuclear Waste Management, IX, L.O. Werme, Materials Research Society, Pittsburgh, PA, 211-218 (1985).

72. F. Bazan, J. Rego, and R.D. Aines, "Leaching of Actinide-doped Nuclear Waste Glass in a Tuff-Dominated System,” Scientific Basis for Nuclear Waste Management, X, J.K. Bates and W.B. Seefeldt (Eds.), Materials Research Society, Pittsburgh, PA, 447-458 (1987).

73. E.Y. Vernaz and N. Godon, "Leaching of Actinides from Nuclear Waste Glass: French Experience,” Scientific Basis for Nuclear Waste Management, XV, C.G. Sombret (Ed.), Materials Research Society, Pittsburgh, PA, 37-48 (1992).

74. W.L. Ebert, S.F. Wolf, and J.K. Bates, “The Release of Technetium from Defense Waste Processing Facility Glasses,” Scientific Basis for Nuclear Waste Management, XIX, W.M. Murphy and D.A. Knecht (Ed.), Materials Research Society, Pittsburgh, PA, 221-227 (1996).

75. B.P. McGrail, "Waste Package Component Interactions with Savannah River Defense Waste Glass in a Low-Magnesium Salt Brine,” Nuclear Technology, 168186 (1986).

76. J.E. Mendel (Compiler), Final Report of the Defense High-Level Waste Leaching Mechanisms Program, US DOE Report PNL-5157, Battelle Pacific Northwest Laboratories, Richland WA (1984).

77. L.L. Hench and D.E. Clark, “Physical Chemistry of Glass Surfaces,” J. Non-Cryst. $\underline{\text { Solids, }} \underline{\text { 28, }}$ 83-105 (1978).

78. L.L.Hench and D.E. Clark, "Surface Properties and Performance Prediction of Alternative Waste Forms,” NUREG/CR-3472, Vol. 2 (1986).

79. J.D. Rimstidt and H.Z. Barnes, "The Kinetics of Silica-Water Reactions," Geochim. Comochim. Acta, 44, 1683-1699 (1980).

80. E.H. Oelkers, “General Kinetic Description of Multioxide Silicate Mineral and Glass Dissolution,” Geochim. Cosmochim. Acta, 65 [21], 3703-3719 (2001). 
81. E.H. Oelkers, J. Schott and J.L. Devidal, "The effect of Aluminum, pH and Chemical Affinity on the Rates of Aluminosilicate Dissolution Reactions,” Geochim. Cosmochim. Acta, 58, 2011-2024 (1994).

82. A.C. Lasaga and A. Luttge, "Mineralogical Approaches to Fundamental Crystal Dissolution Kinetics,” Am. Mineralogist, 89, 527-540 (2004).

83. P. Aagaard and H. C. Helgeson, "Thermodynamic and Kinetic Constraints on Reaction Rates Among Minerals and Aqueous Solutions, I. Theoretical Considerations,” Amer. J. Sci., 282, 237-285 (1982).

84. H.C. Helgeson, W.M. Murphy, and P. Aagaard, "Thermodynamic and Kinetic Constraints on Reaction Rates Among Minerals and Aqueous Solutions, II. Rate Constants, Effective Surface Area, and the Hydrolysis of Feldspar," Geochimica et Cosmochimica Acta, 48, 2405-2432 (1984).

85. A.C. Lasaga, "Chemical Kinetics of Water-Rock Interactions,” J. Geophys. Res., B6, 4009-40025 (1984).

86. W. Ebert, “Defense High Level Waste Glass Degradation,” Office of Civilian Radioactive Waste Management Analysis/Model, ANL-EBS-MD-000016, Rev.00 ICN01 (December 2000).

87. F.M. Mann, R.J. Puigh, II, S.H. Finfrock, E.J. Freeman, R. Khaleel, D.H. Bacon, M.P. Bergeron, B.P. McGrail, S.K. Wurstner, K. Burgard, W.R. Root, and P.E. LaMont. "Hanford Immobilized Low-Activity Tank Waste Performance Assessment: 2001 Version,” U.S. DOE Report DOE/ORP-2000-24 Rev. 0, Richland, WA (2001).

88. E.H. Oelkers and S.R. Sislason, "The Mechanism, Rates, and Consequences of Basaltic Glass Dissolution: I. An Experimental Study of the Dissolution Rates of basaltic Glass as a Function of Aqueous $\mathrm{Al}, \mathrm{Si}$, and Oxalic Acid Concentration at $25^{\circ} \mathbf{C}$ and pH $=3$ and 11," Geochim. Cosmochim. Acta, 65 [21], 3671-3681 (2001).

89. Y. Linard, T. Advocat, C. Jegou, P. Richet, "Thermochemistry of Nuclear Waste Glasses: Application to Weathering Studies,” J. Non-Crystalline Solids 289, 135143 (2001).

90. E. Vernaz, S. Gin, C. Jegou, and I. Ribet, "Present Understanding of R7T7 Glass Alteration Kinetics and Their Impact on Long-Term Behavior Modeling” J. Nucl. Materials, 298 (1-2), 27-36 (2001).

91 W.L. Ebert, "Testing Protocols for GNEP Waste Forms," (in preparation) 
WSRC-STI-2008-00268

Revision 0

92. Standard Practice for Prediction of the Long-Term Behavior of Waste Package Materials Including Waste Forms Used in the Geologic Disposal of High-Level Nuclear Waste, ASTM Standard C1174, American Society for Testing and Materials, Annual Book of ASTM Standards, Vol 12.01, West Conshohocken, PA (2008).

93. Thor ${ }^{\circledR}$ Treatment Technologies, “Pilot Plant Report for Treating T48H Simulants Carbonate Flowsheet,” Document Number 28927-WEC-RPT-00001 : Rev.2 (May 2007).

94. C.M. Jantzen, "Characterization and Performance of Fluidized Bed Steam Reforming (FBSR) Product as a Final Waste Form,” Ceramic Transactions 155, 319-329 (2004).

95. J.M. Pareizs, C.M. Jantzen, and T.H. Lorier "Durability Testing of Fluidized Bed Steam Reformer (FBSR) Waste Forms for High Sodium Wastes at Hanford and Idaho,” U.S. DOE Report WSRC-TR-2005-00102 (2005).

96. C.M. Jantzen, J.M. Pareizs, T.H. Lorier, and J.C. Marra "Durability Testing of Fluidized Bed Steam Reforming (FBSR) Products,” Ceramic Transactions, 176, 121-137 (2005).

97. C.M. Jantzen, T.H. Lorier, J.C. Marra, and J.P. Pareizs, "Durability Testing of Fluidized Bed Steam Reforming (FBSR) Waste Forms,” Waste Management '06, Paper \#6373 (2006).

98. B.P. McGrail, H.T. Schaef, P.F. Martin, D.H. Bacon, E.A. Rodriguez, D.E. McCready, A.N. Primak, and R.D. Orr, "Initial Evaluation of Steam-Reformed Low Activity Waste for Direct Land Disposal,” U.S. DOE Report PNWD-3288 (2003).

99. B.P. McGrail, E.M. Pierce, H.T. Schaef, E.A. Rodriguez, J.L. Steele, A.T. Owen, and D.M. Wellman, "Laboratory Testing of Bulk Vitrified and Steam-Reformed Low-Activity Forms to Support a Preliminary Assessment for an Integrated Disposal Facility,” U.S. DOE Report PNNL-14414 (2003).

100. T.H. Lorier, J.M. Pareizs, and C.M. Jantzen, “Single Pass Flow Through (SPFT) Testing of Fluidized Bed Steam Reforming (FBSR) Waste Forms,” U.S. DOE Report, WSRC-TR-2005-00124 (2005).

101. C.M. Jantzen, T.H. Lorier, J.M. Pareizs, and J.C. Marra, "Fluidized Bed Steam Reformed (FBSR) Mineral Waste Forms: Characterization and Durability Testing,” Scientific Basis for Nucl. Waste Management XXX, D. Dunn (Ed.) 379386 (2007). 
WSRC-STI-2008-00268

Revision 0

102. Y. Xiong and S.A. Wood, "Experimental Determination of the Hydrothermal Solubility of $\mathrm{ReS}_{2}$ and $\mathrm{Re}-\mathrm{ReO}_{2}$ Buffer Assemblage and Transport of Rhenium Under Supercritical Conditions," Geochemical Transactions, 3, 1-12 (2002).

103. D.G. Brookins, “Geochemical Aspects of Radioactive Waste Disposal,” SpringerVerlag, New York, 347pp. (1984).

104. M.P. Tole, "Factors Controlling the Kinetics of Silicate-Water Interactions," Unpublished PhD Thesis, The Pennsylvania State Univeristy, University Park, PA (March 1982).

105. M.P. Tole, A.C. Lasaga, C. Pantano, and W.B. White, "The Kinetics of Dissolution of Nepheline (NaAlSiO 4 ),” Geochim. Cosmochim. Acta 50,(3), 379-392 (1986).

106. K.G. Knauss, W.L. Bourcier, K.D. McKeegan, C.I. Merzbacher, S.N. Nguyen, R.J. Ryerson, D.K. Smith, H.C. Weed, and L. Newton, L. "Dissolution Kinetics of a Simple Analogue Nuclear Waste Glass as a Function of pH, Time, and Temperature,” Sci.Basis Nucl. Waste Mgt., XIII, Mat. Res. Soc., Pittsburgh, PA, 371-381 (1990).

107. T.H. Lorier, C.M. Jantzen, J.C. Marra, and J.M. Pareizs, "Feed Reactivity Study for Fluidized Bed Steam Reformer Processing,” Ceramic Trans. V. 176, 111-119 (2006).

108. E. Puura and I. Neretnieks, "Atmospheric Oxidation of the Pyritic Waste Rock in Maardu, Estonia, 2: An Assessment of Aluminosilicate Buffering Potential," Environ Geol. 39 [6], 560-566 (2000)

109. C.M. Jantzen, J.B. Pickett, and I. Joseph, “Toxic Characteristic Leaching Procedure (TCLP) Testing of Waste Glass and K-3 Refractory: Revisited,” Environmental Issues and Waste Management Technologies in the Ceramic and Nuclear Industries, V, G. T. Chandler (Eds.), Ceramic Transactions, V. 107, 271-280 (2000).

110. C.M. Jantzen, "Phosphate Additions to Borosilicate Waste Glass Cause Phase Separation,” U.S. DOE Report DPST-86-389, E.I. duPont deNemours \& Co., Aiken, SC (April 15, 1986).

111. C.M. Jantzen and K.G. Brown, "Impact of Phase Separation on Waste Glass Durability,” Ceramic Transactions, V. 107, G. T. Chandler (Eds.), 289-300 (2000).

112. A.D. Cozzi and C.M. Jantzen, “ Glass Durability Along the Compositional Continuum Between a Phase Separated Frit and a Homogeneous Glass," Ceramic Transactions, V. 107, G. T. Chandler (Eds.), 301-308 (2000). 
113. D.R. Clarke, "Preferential Dissolution of an Intergranular Amorphous Phase in a Nuclear Waste Ceramic,” J. Am. Ceram. Soc., 64, C89-90 (1981).

114. J.A. Cooper, D.R. Cousens, J.A. Hanna, R.A. Lewis, S. Myhra, R.L. Segall, R.St.C. Smart, P.S. Turner,a nd T.J. White, "Intergranular Films and Pore Surfaces in Synroc C: Structure, Composition, and Dissolution characteristics,” J. Am. Ceram. Soc, 69 [4] (1986).

115. W.J. Buykx, K. Hawkins, D.M. Levins, H. Mitamura, R.St. C. Smart, G.T. Stevens, K.G. Watson, D. Weedon, and T.J. White, "Titanate Ceramics for the Immobilization of Sodium-Bearing High-Level Nuclear Waste,” J. Am. Ceram. Soc. 71 [8], 768-88 (1988).

116. F.J. Dickson, H. Mitamura, and T.J. White, “Radiophase Development in HotPressed Alkoxide-Derived Titanate Ceramics for Nuclear Waste Stabilization,” J. Am. Ceram. Soc., 72 [6] 1055-1059 (1989).

117. W.J. Buykx, D.M. Levins, Roger St.C. Smart, K.L. Smith, G.T. Stevens, K.G. Watson, D. Weedon and T.J. White, "Interdependence of Phase Chemistry, Microstructure, and Oxygen Fugacity in Titanate Nuclear Waste Ceramics,” J. Am. Ceram. Soc. 73 [5], 1201-1207 (1990).

118. W.J. Buykx, D.M. Levins, Roger St.C. Smart, IK.L. Smith, G.T. Stevens, K.G. Watson, and T.J. White, "Processing Impurities as Phase Assemblage Modifiers in Titanate Nuclear Waste Ceramics,” J. Am. Ceram. Soc. 73, 217-225 (1990).

119. H. Mitamura, S. Matsumoto, K.P. Hart, T. Miyazaki, E.R. Vance, Y. Tamura, Y. Togashi, and T.J. White, “Aging Effects on Curium-Dopped Titantate Ceramics Containing Sodium-Bearing High-Level Nuclear Waste,” J. Am. Ceram. Soc., 75[2], 392-400 (1992).

120. C.M. Jantzen and D.F. Bickford, "Leaching of Devitrified Glass Containing Simulated SRP Nuclear Waste," Sci. Basis for Nuclear Waste Management, VIII, C.M. Jantzen, J.A. Stone and R.C. Ewing (eds.), Materials Research Society, Pittsburgh, PA 135-146 (1985).

121. C.M. Jantzen and M.J. Plodinec, "Thermodynamic Model of Natural, Medieval, and Nuclear Waste Glass Durability," J. Non-Cryst. Solids, 67, 207-233 (1984).

122. M.J. Plodinec, C.M. Jantzen, and G.G. Wicks, "Thermodynamic Approach to Prediction of the Stability of Proposed Radwaste Glasses," Advances in Ceramics, $\underline{8}, 491-495$ (1984).

123. C.M. Jantzen, “Thermodynamic Approach to Glass Corrosion” in Corrosion of Glass, Ceramics, and Ceramic Superconductors, Noyes Publications, Park Ridge, NJ 
07656, 153-215 (1992).

124. C.M. Jantzen, J.B. Pickett, K.G. Brown, T.B. Edwards, and D.C. Beam, "Process/Product Models for the Defense Waste Processing Facility (DWPF): Part I. Predicting Glass Durability from Composition Using a Thermodynamic Hydration Energy Reaction MOdel (THERMO),” US DOE Report WSRC-TR93-0672, 464p. (September, 1995).

125. C.M. Jantzen, J.B. Pickett, K.G. Brown, and T.B. Edwards, “Method of Determining Glass Durability (THERMO ${ }^{\mathrm{TM}}$ ),” U.S. Patent \# 5,846,278 (December $8,1998)$

126. J.M. Welch, R.L. Miller and J.E. Flinn, EGG-FM-6059, 43p. (1983).

127. C.M. Jantzen, N.E. Bibler, D.C. Beam, and M.A. Pickett, “Characterization of the Defense Waste Processing Facility (DWPF) Environmental Assessment (EA) Glass Standard Reference Material,” U.S. DOE Report WSRC-TR-92-346, Rev.1, 92p (February, 1993).

128. C.M. Jantzen, N.E. Bibler, D.C. Beam, and M.A. Pickett, “Development and Characterization of the Defense Waste Processing Facility (DWPF) Environmental Assessment (EA) Glass Standard Reference Material,” Environmental and Waste Management Issues in the Ceramic Industry, Ceramic Transactions, 39, American Ceramic Society, Westerville, OH, 313-322 (1994).

129. H.D. Schreiber, P.G. Leonhard, R.G. Nofsinger, M.W. Henning, C.W. Schreiber, and S.J. Kozak, “Oxidation-Reduction Chemistry of NonMetals in a Reference Borosilicate Melt,” Advances in the Fusion of Glass, D.F. Bickford, W.E. Horsfall, F.E. Wooley, E.N. Boulos, J.N. Lingscheit, F. Harding, F. Olix, W.C. LaCourse, and L.D. Pye (Eds.), Am. Ceram. Soc., Westerville, OH, 29.1-19.14 (1988).

130. H.D. Schreiber and A.L. Hockman, “Redox Chemistry in Candidate Glasses for Nuclear Waste Immobilization,” J. Am. Ceram. Soc., 70[8], 591-594 (1987).

131. J.B. Mason, J. McKibbin, K. Ryan, and D. Schmoker, "Steam Reforming Technology for Denitration and Immobilization of DOE Tank Wastes,” Waste Management 03 (2003).

132. D.W. Marshall, N.R. Soelberg, K.M. Shaber, “THOR ${ }^{\text {sm }}$ Bench-Scale Steam Reforming Demonstration,” U.S. DOE Report INEEL/EXT.03-00437, Idaho National Engineering \& Environmental Laboratory, Idaho Falls, ID (2003).

133. N.R. Soelberg, D.M. Marshall, S.O. Bates, and D.D. Siemer, “SRS Tank 48H Steam Reforming Proof-of-Concept Test Report”, INEEL/EXT-03-01118, Rev 1 Idaho National Engineering and Environmental Laboratory, Idaho Falls, ID (May 2004). 
134. A.L. Olson, N.R. Soelberg, D.W. Marshall, and G.L. Anderson, "Fluidized Bed Steam Reforming of INEEL SBW Using THOR ${ }^{\mathrm{sm}}$ Mineralizing Technology;” U.S. DOE Report INEEL/EXT-04-02564; 2004.

135. A.L. Olson, N.R. Soelberg, D.W. Marshall, G.L. Anderson, "Fluidized Bed Steam Reforming of Hanford LAW Using THOR ${ }^{\text {sm }}$ Mineralizing Technology;” U.S. DOE Report INEEL/EXT-04-02492; Idaho National Engineering \& Environmental Laboratory: Idaho Falls, ID, 2004.

136. C.M. Jantzen, "Fluidized Bed Steam Reforming of Organic and Nitrate Containing Salt Supernate," Environmental Issues and Waste Management Technologies X, J.D. Vienna, C.C. Herman, and S.L. Marra (Eds), Ceramic Transactions 168, 68-79 (2005).

137. C.M. Jantzen, "Disposition of Tank 48H Organics by Fluidized Bed Steam Reforming (FBSR),” U.S. DOE Report WSRC-TR-2003-00352 (September 18, 2003).

138. N.R. Soelberg, D.W. Marshall, S.O. Bates, and D.D. Taylor, "Phase 2 THOR Steam Reforming Tests for Sodium Bearing Waste Treatment," U.S. DOE Report INEEL/EXT-04-01493, Rev. 1 (2004)

139. Test Method for Static Leaching of Monolithic Waste Forms for Disposal of Radioactive Waste, ASTM Standard C1220, American Society for Testing and Materials, Annual Book of ASTM Standards, Vol 12.01, West Conshohocken, PA (2008).

140. Standard Test Method for Diffusive Releases from Solidified Waste and a Computer Program to Model Diffusive, Fractional Leaching from Cylindrical Waste Forms, Standard C1308, Annual Book of ASTM Standards Vol. 12.01, American Society for Testing and Materials, West Conshohocken, PA (2008).

141. Standard Practice for Measurement of the Glass Dissolution Rate Using the SinglePass Flow-Through Test Method, Standard C1662, Annual Book of ASTM Standards Vol. 12.01, American Society for Testing and Materials, West Conshohocken, PA (2008).

142. D.J. Wronkiewicz, J.K. Bates, T.J. Gerding, E. Veleckis, and B.S. Tani. "Uranium Release and Secondary Phase Formation During Unsaturated Testing of UO2 at 90C,” Journal of Nuclear Materials, 190, 107-127. (1992)

143. B.P. McGrail, P.F. Martin, and C.W. Lindenmeier. "Accelerated Testing of Waste Forms Using a Novel Pressurized Unsaturated Flow (PUF) Method,” Material Research Society Symposium Proceedings, 465, 253-260 (1997). 
144. W.L. Ebert, J.K. Bates, and W.L. Bourcier. "The Hydration of Borosilicate Waste Glass in Liquid Water and Steam at $\mathbf{2 0 0}^{\circ} \mathbf{C}$," Waste Management,11, 205-221. (1991)

145. S. Ribet, I.S. Muller, I.L. Pegg, S. Gin, and P. Frugier, “Compositional Effects on the Long-Term Durability of Nuclear Waste Glasses: A Statistical Approach,” Sci. Basis for Nuclear Waste Management XXVIII, J.M. Hanchar, S. StroesGascoyne, L. Browning (Eds.), Materials Research Society, Pittsburgh, PA, 309-314 (2004).

146. I.S. Muller, S. Ribet, I.L. Pegg, S. Gin, and P. Frugier, “Characterization of Alteration Phases on HLW Glasses After 15 Years of PCT Leaching,” Ceramic Transactions, 176, American Ceramic Society, Westerville, OH, 191-199 (2006).

147. C.M. Jantzen, "Prediction of Glass Durability as a Function of Environmental Conditions," Proceedings of the Symposium on Materials Stability and Environmental Degradation, A. Barkatt et al. (Eds.), Materials Research Society, Pittsburgh, PA, 143-159 (1988).

148. C.M. Jantzen, "Prediction of Glass Durability as a Function of Glass Composition and Test Conditions: Thermodynamics and Kinetics,” Proceedings of the First Intl. Conference on Advances in the Fusion of Glass, American Ceramic Society, Westerville, OH, p.24.1-24.17 (1988).

149. J.K. Bates, E.C. Buck, N.L. Dietz, T. DiSanto, W.L. Ebert, J.W. Emery, J.A. Fortner, L.D. Hafenrichter, J.C. Hoh, J.S. Luo, L. Nunez, M.T. Surchik, S.F. Wolf, and D.J. Wronkiewicz, “ANL Technical Support Program for DOE Office of Environmental Management,” U.S. DOE Report ANL-96/11, Argonne National Laboratory, Argonne, IL (July, 1996).

150. G.G. Wicks, “Nuclear Waste Glasses: Corrosion Behavior and Field Tests,” Corrosion of Glass, Ceramics, and Ceramic Superconductors, D.E. Clark and B.K. Zoitos, Noyes Publications, Park Ridge, NJ, 218-268 (1992).

151. G.G. Wicks, P.E. O’Rouke, and P.G. Whitkop, “The Chemical Durability of Savannah River Plant Waste Glass as a Function of Groundwater pH,” U.S. DOE Report DP-MS-81-104, E.I. duPont deNemours \& Co., Savannah River Laboratory, Aiken, SC (May, 1982).

152. C.M. Jantzen, D.I. Kaplan, N.E. Bibler, D.K. Peeler, and M.J. Plodinec, "Performance of a Radioactive High Level Waste Glass After 24 Years Burial," J. Nucl. Materials, 378, 244-256 (2008). 
153. W.L. Ebert, J.K. Bates, C.R. Bradley, E.C. Buck, N.L. Dietz, and N.R. Brown, “The Long-Term Alteration of Borosilicate Waste Glasses,” Ceramic Transactions, 39, American Ceramic Society, Westerville, OH, 333-340 (1994).

154. B.P. McGrail, W.L. Ebert, A.J. Bakel, D.K. Peeler, “Measurement of Kinetic Rate Law Parameters on a Na-Ca-Al Borosilicate Glass for Low-activity Waste.” Journal of Nuclear Materials 249:175-189 (1997).

155. S. Brunauer, P.H. Emmett, and E. Teller, "Adsorption of Gases in Multimolecular Layers,” J. Physical Chem. 60, 309-319 (1938).

156. P. Zhao, S. Roberts, and W. Bourcier, “Technical Progress Report on Single Pass Flow Thorugh Tests of Ceramic Waste Forms for Plutonium Immobilization,” U.S. DOE Report UCRL-ID-143361, Rev. 1 (2000).

157. F. Bart, G. Leturcq, and H. Rabiller, “Chemical Durability of Iron-Substituted Hollandite Ceramics for Cesium Immobilization,” Ceramic Trans. 168. 217-224 (2005)

158. J.P. Icenhower, D.M. Strachan, M.M. Lindberg, E.A. Rodriguez, J.L. Steele, "Dissolution Kinetics of Titanate-Based Ceramic Waste Forms: Results from Single-Pass Flow Tests on Radiation Damaged Specimens,” U.S. Doe Report PNNL-14252, Pacific Northwest National Laboratory, Richland, WA (May 2003).

159. K.G. Knauss and T.J. Wolery, “Dependence of Albite Dissolution Kinetics on pH and Time at $2^{\circ} \mathbf{C}$ and $70^{\circ} \mathbf{C}$," Geochim. Cosmochim. Acta, 50, 2481-2497 (1986). 
DISTRIBUTION:

K. Ryan - TTT

B. Evans - TTT

P. Statts - TTT

B. Eldridge - TTT

B. Mason - TTT

A. Olsen - TTT

J.C. Griffin - 773-A

J.E. Marra - 773-A

J.C. Marra -773-42A

S.L. Marra - 773-A

C.L. Crawford - 773-42A

M.R. Williams -786-5A

W.G. Daniel - 999W

A.B. Barnes - 999W

D.K. Peeler - 999W

K. M. Fox $-999 \mathrm{~W}$

P.R. Burket - 773-42A

C.C. Herman - 999W 